Discussion Paper No. 17-006

\title{
The Use of SME Tax Incentives in the European Union
}

Sören Martin Bergner, Rainer Bräutigam, Maria Theresia Evers, and Christoph Spengel

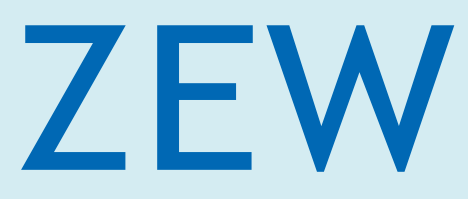

Zentrum für Europäische Wirtschaftsforschung $\mathrm{GmbH}$ Centre for European Economic Research 
Discussion Paper No. 17-006

\title{
The Use of SME Tax Incentives in the European Union
}

\author{
Sören Martin Bergner, Rainer Bräutigam, \\ Maria Theresia Evers, and Christoph Spengel
}

Download this ZEW Discussion Paper from our ftp server:

http://ftp.zew.de/pub/zew-docs/dp/dp17006.pdf

Die Discussion Papers dienen einer möglichst schnellen Verbreitung von neueren Forschungsarbeiten des ZEW. Die Beiträge liegen in alleiniger Verantwortung der Autoren und stellen nicht notwendigerweise die Meinung des ZEW dar.

Discussion Papers are intended to make results of ZEW research promptly available to other economists in order to encourage discussion and suggestions for revisions. The authors are solely responsible for the contents which do not necessarily represent the opinion of the ZEW. 


\title{
The Use of SME Tax Incentives in the European Union
}

\author{
Sören Martin Bergner*, Rainer Bräutigam**, Maria Theresia Evers**, Christoph Spengel***
}

January 2017

This paper discusses the impact and the appropriateness of tax incentives for small and medium-sized enterprises (SMEs) in the European Union. First, we provide a survey of implemented tax incentives specifically targeted at SMEs in the 28 EU Member States. Building hereon, we measure the impact of these regimes on the effective tax burdens of targeted companies. We find that SME tax incentives are a commonly used measure among European policy makers. The vast majority of regimes, however, only marginally reduce the tax liability of SMEs. If major reliefs are available, they mostly stem from special tax rates whereas tax credits and special allowance play a minor role. In the second main part of the analysis, we examine the arguments potentially justifying the usage of SME tax incentives. As a main result, small firms per se do not create more jobs and innovations nor do they face insurmountable financing constraints. The existence of market failures commonly associated with SMEs - and possibly warranting the use of SME tax incentives - can therefore not be confirmed. Instead, disproportionate tax compliance costs for small entities constitute the most compelling argument for a special tax treatment. These compliance costs can most appropriately be addressed by administrative reliefs. Special tax rates, tax credits and allowances, in contrast, are not only inefficient but also ineffective in this regard. Instead of improving the neutrality of the overall tax system, the latter are likely to add further distortions and unnecessary complexity. Altogether, the focus of policy-makers should thus shift from providing discriminatory incentives to the design of a generally neutral and simple tax system, which would benefit small as well as large enterprises.

JEL Classification Code: H24, H25

Keywords: SME, Tax Policy, European Union

\footnotetext{
*: University of Mannheim

**: ZEW and University of Mannheim

***: University of Mannheim and ZEW

Corresponding Author: Sören Martin Bergner, bergner@uni-mannheim.de
} 


\section{Introduction}

Recently, public discussions on tax policy have mainly centered around profit shifting activities by large, multinational firms. ${ }^{1}$ The majority of businesses, however, is made up of small and medium-sized enterprises (SMEs). In the European Union, they account for $99.8 \%$ of all businesses and $67 \%$ of total employment. ${ }^{2}$ Moreover, SMEs are widely perceived to be the engine of growth and innovation for the economy. ${ }^{3}$ Accordingly, the European Commission (EC) regards the "capacity to build on the growth and innovation potential of small and medium-sized enterprises" to be incremental for the future prosperity of the European Union (EU). ${ }^{4}$ The creation of a "world-class environment for SMEs" has thus become a major goal of the European Commission. ${ }^{5}$

While the need of an attractive business environment for SMEs is widely agreed upon, it is less apparent how to create it. SMEs face disadvantages with regard to financing, competition failures and disproportionate regulatory burdens compared to large enterprises. An attractive business environment minimizes the impact of these obstacles and aims at providing a level playing field for firms of all sizes, industries and legal forms. ${ }^{6}$ Naturally, taxation is an important component of the regulatory framework in which businesses operate. It constitutes a major, inevitable cost factor for all businesses. For policy-makers, taxation is a particularly interesting feature of the business environment as it can be directly influenced and controlled through legislation. ${ }^{7}$ Occasionally, however, tax legislation is excessively and inappropriately utilized to compensate for problems not related to taxation and the creation of a neutral and efficient tax system takes a back seat. ${ }^{8}$

The use of tax incentives specifically targeted at SMEs may be one of these occasions. Preferential treatment for certain groups of taxpayers generally interferes with the neutrality and the efficiency of the tax system and the social benefits of any tax incentive have

\footnotetext{
${ }^{1}$ See Fuest/Spengel/Finke/Heckemeyer/Nusser (2013) pp. 307 ff.; OECD (2013a) pp. 9 ff.

${ }^{2}$ See European Commission (2015a) p. 7.

${ }^{3}$ See Bundesministerium für Wirtschaft und Energie (2014) p. 2; European Commission (2013) pp. 3 f.; OECD (2009a) p. 22.

${ }^{4}$ See European Commission (2008) p. 2.

${ }^{5}$ See European Commission (2008) p. 2. SMEs were again prominently featured in the Commission's 2020 Strategy as a key driver of smart, sustainable and inclusive economic growth. The special focus of some of the EC's flagship initiatives on SMEs as well the Annual Reports on the Performance of SMEs constitute further indicators for SMEs' perceived significance in the European Union. See European Commission (2010a) pp. 10 ff.; European Commission (2015a) pp. 7 ff.

${ }^{6}$ See European Commission (2013) pp. 8 ff.; Lee (2014) pp. 183 ff.; BIS (2015) pp. 74 ff.

${ }^{7}$ See OECD (2009a) pp. $31 \mathrm{ff}$; European Commission (2015b) pp. $75 \mathrm{ff}$.

${ }^{8}$ See OECD (2001a) pp. $87 \mathrm{ff}$.
} 
to be carefully weighed against the related costs. ${ }^{9}$ The adequacy of SME tax incentives thus hinges on the desirable traits of small and medium-sized enterprises and incentives' effectiveness in fostering these traits to the benefit of society as a whole. Policy-makers across Europe apparently consider these two prerequisites to be given as SME tax incentives have become a commonly used policy instrument in Europe as well as the rest of the world.

This study analyzes and evaluates the current use of SME tax incentives in the European Union. In this endeavor, we first examine which SME tax incentives are currently offered and how they affect effective tax burdens. The latter is done with the help of the European Tax Analyzer, a proven simulation program for the calculation of effective tax burdens that allows the implementation of a variety of incentive types. In the second step, we analyze in how far tax incentives - especially in their current forms - are an appropriate tool to achieve the abovementioned policy goals associated with the SME sector. We thereby aim at providing policy-makers with clear-cut advice on the usage of special tax treatments for micro, small and medium-sized enterprises.

The remainder of the study is structured as follows. Chapter 2 gives an overview of the currently available tax incentives in the EU before Chapter 3 quantitatively analyzes their impact on effective tax burdens. Building hereon, Section 4 discusses and evaluates the underlying policy rationale for the provision of SME tax incentives before Chapter 5 concludes.

\section{Overview of SME Tax Incentives in the EU}

\subsection{Definition of Small and Medium-Sized Enterprises}

Analyzing SME tax incentives, of course, first requires a definition of the term SME. While a multitude of quantitative as well as qualitative approaches can be found in the academic literature, the most prominent and widely used definition, especially in the EU, has been established by the European Commission. ${ }^{10}$ As the analysis at hand deals with tax

\footnotetext{
${ }^{9}$ See Klemm (2010) p. 324.

${ }^{10}$ The European Commission first published a Commission recommendation on the definition of small and medium-sized enterprises in 1996. Since then the recommendation has been followed by several updates. The following discussion is based on the most recent definition provided by the Commission recommendation of May 6, 2003. Furthermore, the Commission has issued an updated user guide to the SME definition in 2015 that is also drawn upon. See European Commission (1996) pp. 4 ff.; European Commission (2003) pp. 36 ff.; European Commission (2015c) pp. $1 \mathrm{f}$.
} 
incentives in the European Union and legislators who are impacted by the European Commission, we will also refer to this standard in the following.

Table 1: SME definition by the European Commission

\begin{tabular}{|l|ccc|}
\hline Category & Number of employees & Turnover & Balance sheet total \\
\hline Micro & $<10$ & $\leq € 2$ million & $\leq € 2$ million \\
\hline Small & $<50$ & $\leq € 10$ million & $\leq € 10$ million \\
\hline Medium & $<250$ & $\leq € 50$ million & $\leq € 43$ million \\
\hline
\end{tabular}

The SME definition by the European Commission employs three quantitative criteria to distinguish four different size classes. Enterprises are classified as either micro, small, medium-sized or large according to their number of employees, annual turnover and balance sheet totals (see Table 1). Specifically, enterprises need to meet the given employment threshold and either the turnover threshold or the maximum balance sheet total to be assigned to the respective size category. ${ }^{11}$ Besides these quantitative criteria, the SME definition by the European Commission also includes provisions on related parties. An enterprise must not own $25 \%$ or more of the capital or the voting rights of potentially related parties to be considered independent. Furthermore, no external party must hold $25 \%$ or more of the capital or the voting rights of the enterprise. ${ }^{12}$ If these requirements are not met, the thresholds for employment, turnover and balance sheet total apply for the whole group of enterprises instead of the stand-alone entity. ${ }^{13}$

\subsection{Typology of SME Tax Incentives}

Tax incentives are special provisions of the tax code granting preferential treatment to certain activities, investments or taxpayers. ${ }^{14}$ With regard to SME tax incentives, the preferential treatment takes many forms and available options for policy-makers can be broadly categorized along the lines of three key dimensions:

1) Level of taxation: Does the incentive apply on the level of the enterprise or does it benefit the business owner upon extracting income from the business? This distinction primarily applies to businesses that are not taxed transparently (i.e., corporations, limited liability companies and - in some countries - certain forms of

\footnotetext{
${ }^{11}$ See European Commission (2003) p. 39.

${ }^{12}$ Exceptions apply to certain kinds of investors such as venture capital investors, business angels, institutional investors or public bodies.

${ }^{13}$ See European Commission (2015c) pp. $16 \mathrm{f}$.

${ }^{14}$ See Zee/Stotsky/Ley (2002) p. 1498; Klemm (2010) pp. 315 f.
} 
partnerships). In the case of transparently taxed entities (i.e., sole proprietors and partnerships), the two levels cannot be distinguished.

2) Tax liability vs. compliance costs: Does the incentive address the actual tax liability or does it address the compliance costs that are related to the process of determining and settling the tax liability?

3) Input vs. output-based incentives: Does the size of the relief depend on the amount and/or the kind of inputs invested within the enterprise or does it depend on the outcome the investment generates (i.e., taxable income)? Input-based tax incentives include special depreciation schemes, investment allowances and tax credits while special tax rates, exemptions and tax holidays constitute the most common outputbased measures.

In addition to the abovementioned three dimensions, further options arise in the design of SME tax incentives, in particular with regard to additional eligibility restrictions not relating to firm size. Such restrictions may refer to firm age (i.e., only new or young firms), location (i.e., only enterprises in certain regions), time (i.e., incentives only available for a certain period) and the sort of activity performed by the taxpayer (i.e., only businesses in a certain industry). Moreover, incentives differ with regard to their way of targeting SMEs. They can either explicitly or implicitly target firms of a certain size. Explicit SME incentives use clear-cut thresholds on quantitative size criteria (e.g., turnover) whereas implicit measures achieve a preferential treatment of SMEs in other ways. For example, limiting the absolute amount of available reliefs can induce disproportional advantages for SMEs without explicitly excluding large entities. If the caps are chosen appropriately, the relief only makes up a small amount of large businesses' overall tax liability whereas small enterprises benefit more in relative terms.

For the purpose of this analysis, the term SME tax incentive is defined very broadly as any kind of special tax treatment that is particularly beneficial for enterprises within the SME spectrum given by the European Commission. ${ }^{15}$ This includes all benefits either emanating from schemes that are exclusively applicable to SMEs (explicit incentives) as well as those provisions that are especially advantageous for SMEs despite being generally applicable to all enterprises (implicit incentives). Given the abundance of regimes and the model restrictions of the quantitative analysis, the following analysis will, however, primarily focus on those incentives being applicable to corporate entities and those addressing the size

\footnotetext{
${ }^{15}$ See European Commission (2003) pp. 36 ff.
} 
of the actual tax liability (i.e., no purely administrative reliefs). ${ }^{16}$ Moreover, taxes not relating to income are neglected.

\subsection{Available SME Tax Incentives in the EU}

Currently, a broad spectrum of tax incentives is offered to SMEs in the EU. Disregarding administrative reliefs and provisions for venture capital funds, 18 of $28 \mathrm{EU}$ Member states target tax benefits specifically at SMEs (see Figure 1). ${ }^{17}$ In total, more than 60 regimes exist. Geographically, Scandinavian and Eastern European countries mostly refrain from supporting SMEs through the tax code while Southern and Western Europe seem more convinced of the usefulness of such measures. Countries such as Belgium, France and Spain, for example, have implemented a multitude of incentives for micro, small and medium-sized enterprises.

Among the different incentive types, preferential tax rates are the most common instrument to support SMEs. 10 of the 28 EU Member States feature CIT rate schedules favoring small businesses over large ones. Importantly, special tax rates usually apply to a wide range of micro and small enterprises as they are rarely connected to eligibility criteria not related to firm size. Input-based incentives for SMEs are commonly used as well. Specifically, investment allowances, tax credits and accelerated depreciation schemes can each be found in about a quarter of the EU Member States. The input-based regimes often come along with extensive eligibility criteria, though. These criteria restrict the benefits to certain kinds of companies and investments, e.g., only new companies, only R\&D-related investments or only companies in certain regions. In other instances, the incentives are granted under certain conditions such as the creation of additional jobs or the reinvestment of preferentially treated income. As a consequence, the number of affected SMEs as well as the size of average effective reliefs can be expected to be much lower for tax allowances, tax credits and depreciation schemes than for output-based measures. Overall, it appears that preferential tax rates are the primary instrument to support the small business sector as a whole whereas input-based and shareholder-level incentives are mostly designed to serve very specific purposes for which SMEs are considered key contributors. These purposes include the creation of jobs as well as the development of new products and technologies. The widespread reliefs provided by output-based measures, on the other hand, could represent an

\footnotetext{
${ }^{16}$ Many regimes apply to corporate as well as non-corporate entities, though, and the trends and patterns in the provisions of SME tax incentives are similar for both sectors. The same is true with regard to the arguments possibly supporting tax benefits for corporate and non-corporate SMEs.

${ }^{17}$ Detailed descriptions of all available regimes can be found in the country reports in Annex 1.
} 
intended compensation for perceived size-related disadvantages of micro and small businesses, e.g., the disproportionate tax compliance burden.

A closer look at the currently available SME incentives also shows that policymakers differentiate between micro, small and medium-sized enterprises. The latter are eligible for not even a third of all SME incentives explicitly referring to size criteria whereas small entities are only excluded from a few regimes. Apparently, the need for tax incentives is perceived to be much stronger for micro and small businesses than for medium-sized enterprises. The size criteria used in tax codes mostly correspond to the criteria from the SME definition of the European Commission (i.e., the number of employees, sales and total assets). The exact thresholds differ regularly, though. As an exception, eligibility for special tax rates mostly depends on income. Interestingly, only few countries abstain from explicit size criteria and favor SMEs implicitly by establishing absolute maximum reliefs. In the Netherlands, for example, the investment allowance as well as the progressive tax rate schedule are open to all companies but the effect relative to the overall tax burden is likely to be negligible for medium-sized and large enterprises due to the small absolute amounts of eligible expenditures and income. Such implicit measures offer the advantage that exceeding the respective thresholds does not vacate the whole relief. Instead, it only changes the marginal treatment for excess investments or profits, which is more conducive to the equity and the neutrality of the tax system.

The denial of refunds is also characteristic of most current SME tax incentives in the EU, i.e., if tax allowances and tax credits exceed the tax base (or the tax liability, respectively) only few countries grant a refund on the excess amount. More commonly, carry forwards or carry backs are granted. In several countries, however, even carry forwards are declined (or severely limited) so that low-profit and loss-making taxpayers forfeit the benefits. Given that low-profit firms in particular have problems to obtain enough capital for their investment projects, the respective incentives could exclude a large share of those taxpayers who are actually intended to be supported. 
Figure 1: Major income tax incentives for small and medium-sized companies in the EU (2015)

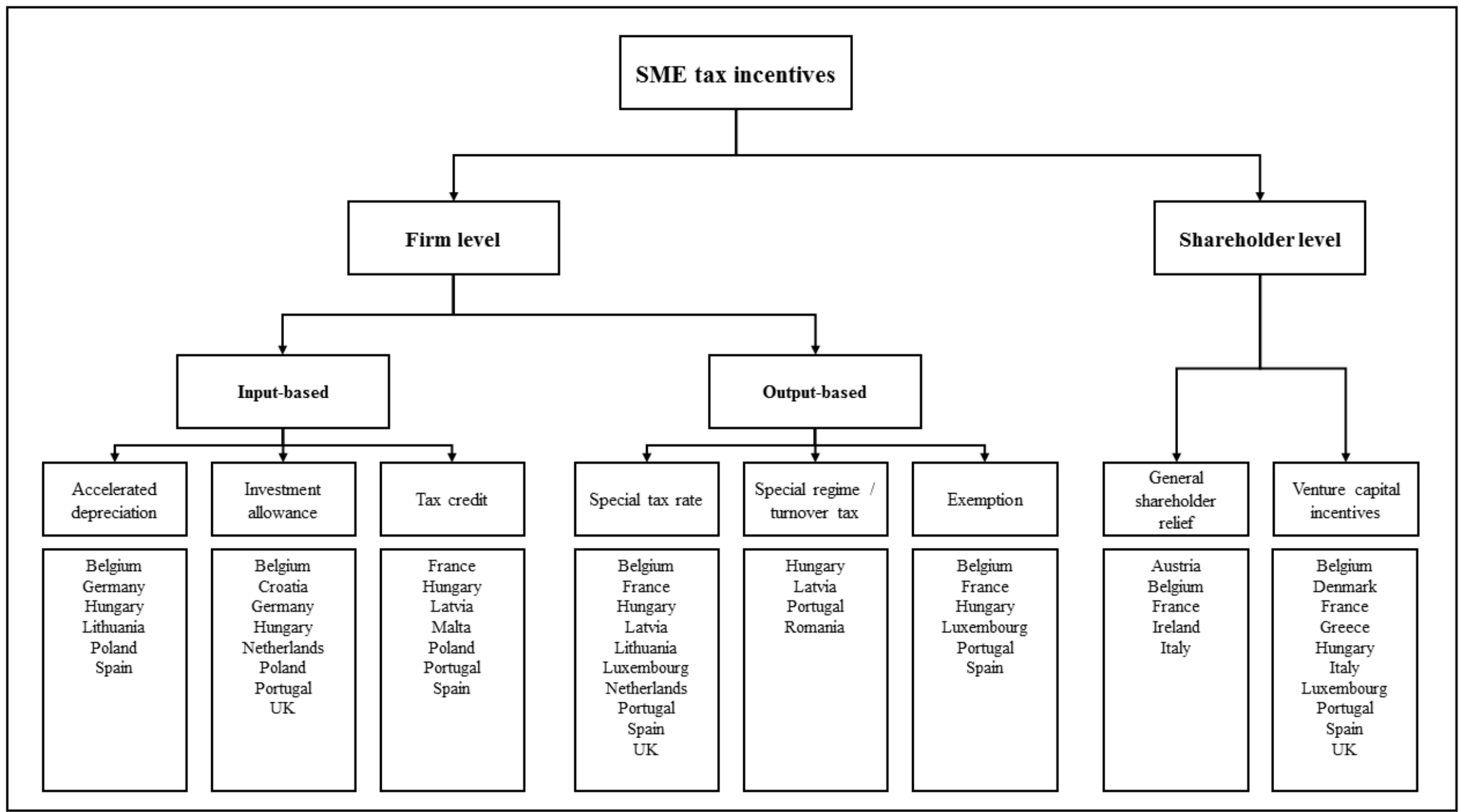


Lastly, the availability of multiple SME tax incentives in some countries is noteworthy. When offered simultaneously, the incentives naturally impact on each other's effectiveness in lowering tax burdens as the effect of a diminished tax base depends on the applicable tax rate and vice versa. An investment allowance for R\&D investments, for example, could lose much of its appeal if the income is subject to a CIT rate of $15 \%$ instead of $33.33 \%$ as in France. Hence, the co-existence of multiple input and output-based regimes adds a significant amount of complexity to the tax system. Given the prominent role of compliance costs for SMEs, ${ }^{18}$ legislators would probably be well-advised to provide the intended reliefs by means of a minimal number of regimes. With regard to the compliance burden, four countries in the EU (Hungary, Latvia, Portugal, Romania also provide the very smallest companies with access to significantly simplified regimes. These regimes build on turnover instead of taxable income and regularly replace several levies at once (e.g., the CIT, the PIT and social security contributions). ${ }^{19}$ The simplifications, of course, also serve the purpose of optimizing net tax revenues, i.e., not incurring overly high administrative costs for the collection of small amounts of taxes from thousands or millions of very small businesses.

\section{Impact of SME Tax Incentives on Effective Tax Levels in the EU}

The qualitative overview of available regimes in Section 2 and Annex 1 shows that SME tax incentives are common practice in the EU. The incentives, however, differ significantly in their design and in their scope of application. The actual impact of available incentives on the majority of micro, small and medium-sized enterprises may therefore be limited for many regimes. If, however, the effects on effective tax burdens were negligible, it would be hard to make a case for tax incentives given the additional compliance and administrative costs. The following quantitative analysis therefore measures the actual effects of SME tax incentives. The calculations also allow conclusions about the proper targeting of SME tax incentives as they help to unveil the relationship between the size of reliefs and firm characteristics such as profitability, capital intensity and capital structure. Lastly, the effective reduction of tax burdens hints at potential distortions of investment and financing decisions introduced by size-dependent tax treatment (large firms versus SMEs but also micro versus small and medium-sized companies). In particular, businesses could be incentivized to not

\footnotetext{
${ }^{18}$ See Sandford/Godwin/Hardwick (1989) pp. 191 ff.; DeLuca/Stilmar/Guyton/Lee/O’Hare (2007) pp. 170 ff.; Eichfelder (2011) pp. $63 \mathrm{ff}$.

${ }^{19}$ Further simplifications (not covered in Figure 1) include simplified accounting regimes, simplified collection procedures and even the exemption from certain levies such as the VAT and some local business taxes. Oftentimes, these simplifications are only available for non-corporate entities, though.
} 
outgrow their current size class, which would, of course, be the opposite of the intended effect of SME tax incentives.

\subsection{European Tax Analyzer}

The quantitative analysis is performed with the help of the European Tax Analyzer, a simulation program to calculate effective average tax burdens for model enterprises in different jurisdictions. For this study, four different model enterprises are considered: a large, a medium-sized, a small and a micro company. In order to sample the model firms, each company in the 28 Member States of the European Union as reported by the AMADEUS database by Bureau von Dijk (see Figure 2) is assigned to one of the four size classes. ${ }^{20}$ Building on this classification, averages of all relevant financial indicators are taken over the companies in each category. Finally, the averages define the respective model enterprises and their characteristics. Put differently, the model companies represent the average European companies in the four size classes.

The basic idea of the European Tax Analyzer is to simulate the development of the model companies twice: one time in a world without taxes and one time in a world with taxes. The difference in firm values between both scenarios ultimately represents the tax burden. The development of balance sheet positions, sales, costs and other financial indicators therefore needs to be simulated over a period of ten years in the next step. The estimates also include macroeconomic data such as interest rates (short- and long-term rates for debtor and creditor) and price increases (primary products, general inflation, wages, real estate and investment goods $)^{21}$ as well as data on the structure and the costs for employees and R\&D. For depreciable assets, it is generally assumed that they are disposed of at the end of their useful lives and replaced by an identical asset. The replacement costs are adjusted for inflation. The initial financial endowments consist of debt and equity. Dividends are distributed annually to shareholders whereas undistributed after-tax profits become retained earnings and can also serve as a further source for acquiring new assets or financing the corporation in general. Due to deriving average European model enterprises from the AMADEUS database, companies have identical pre-tax figures (balance sheet, profit- \& loss-

\footnotetext{
${ }^{20}$ A two-step approach is used to generate the model companies: First, each EU company in the AMADEUS database is classified as either micro, small, medium-sized or large according to the definition by the European Commission. In a second step, average financial indicators (i.e., balance sheet, profit and loss statement, etc.) are determined for each category and form the financial framework of the respective model enterprises.

${ }^{21}$ Interest rates are determined by the average of the monthly short-term and long-term interest rates as provided by the European Central Bank (MFI interest rate statistics). Assumed price increases are determined by the average of monthly or quarterly price indices provided by Eurostat and the Statistical Office of Germany for 2012.
} 
statement and liquidity) and are subject to equal macroeconomic parameters in all countries. As a consequence, differences at the end of the simulation period are exclusively induced by differences in tax codes.

Figure 2: Model companies (European Tax Analyzer)

\begin{tabular}{|c|c|c|c|c|}
\hline Balance Sheet ('000€) & Micro & Small & Medium & Large \\
\hline Total assets & 1,074 & 4,442 & 15,857 & 171,949 \\
\hline Fixed assets & 340 & 1,385 & 5,215 & 58,759 \\
\hline Intangible fixed assets & 21 & 88 & 340 & 5,199 \\
\hline Tangible fixed assets & 284 & 1,139 & 4,111 & 41,151 \\
\hline Other fixed assets & 36 & 158 & 764 & 12,408 \\
\hline Current assets & 734 & 3,057 & 10,642 & 113,190 \\
\hline Stock & 175 & 816 & 2,978 & 27,362 \\
\hline Debtors & 154 & 993 & 2,911 & 41,938 \\
\hline Other current assets & 405 & 1,248 & 4,753 & 43,891 \\
\hline Equity \& liabilities & 1,074 & 4,442 & 15,857 & 171,949 \\
\hline Equity & 509 & 2,268 & 7,035 & 73,194 \\
\hline Common stock & 151 & 659 & 1,694 & 21,306 \\
\hline Other equity & 358 & 1,609 & 5,341 & 51,888 \\
\hline Non-current liabilities & 156 & 601 & 2,558 & 28,000 \\
\hline Long-term debt & 127 & 416 & 1,796 & 19,937 \\
\hline Other non-current liabilities & 28 & 185 & 762 & 8,063 \\
\hline Current liabilities & 410 & 1,572 & 6,264 & 70,755 \\
\hline Loans & 77 & 344 & 1,920 & 22,661 \\
\hline Creditors & 246 & 963 & 3,265 & 32,385 \\
\hline Other current liabilities & 87 & 265 & 1,079 & 15,709 \\
\hline \multicolumn{5}{|l|}{ Profit \& Loss Statement ('000 €) } \\
\hline Sales & 659 & 4,764 & 19,404 & 209,689 \\
\hline Operating profit (loss) & 72 & 381 & 1,348 & 14,278 \\
\hline Profit (loss) before tax & 62 & 342 & 1,237 & 13,369 \\
\hline Profit (loss) after tax & 48 & 264 & 957 & 10,384 \\
\hline \multicolumn{5}{|l|}{ Employment } \\
\hline Employees & 3 & 21 & 90 & 628 \\
\hline Costs of employees ('000 €) & 84 & 634 & 2,703 & 21,939 \\
\hline \multicolumn{5}{|l|}{ Financial Ratios } \\
\hline Return on equity & $10.45 \%$ & $13.15 \%$ & $15.74 \%$ & $16.53 \%$ \\
\hline Profit to turnover ratio after tax & $7.30 \%$ & $5.30 \%$ & $4.93 \%$ & $4.95 \%$ \\
\hline Equity ratio & $47.35 \%$ & $51.06 \%$ & $44.37 \%$ & $42.57 \%$ \\
\hline Personnel intensity & $14.18 \%$ & $14.80 \%$ & $14.97 \%$ & $11.42 \%$ \\
\hline Intensity of machinery & $26.43 \%$ & $25.64 \%$ & $23.63 \%$ & $23.93 \%$ \\
\hline Stock intensity & $16.29 \%$ & $18.38 \%$ & $18.78 \%$ & $15.91 \%$ \\
\hline
\end{tabular}

Each model enterprise is a corporate entity. Hence, the relevant tax codes applied in the taxation of the model company throughout the calculation period are those applying to corporations in the EU Member States in 2015. Importantly, the multi-period approach 
combined with the modelling of an actual company allows the consideration of a multitude of tax rules that would not be possible otherwise. Above all, tax bases and tax codes' impact thereon can be accounted for. ${ }^{22}$ This is of particular importance for examining SME-specific tax incentives that often modify tax bases and restrict eligibility by thresholds referring to balance sheet totals, turnover or the number of employees.

Figure 3: Calculation of effective tax burden (European Tax Analyzer)

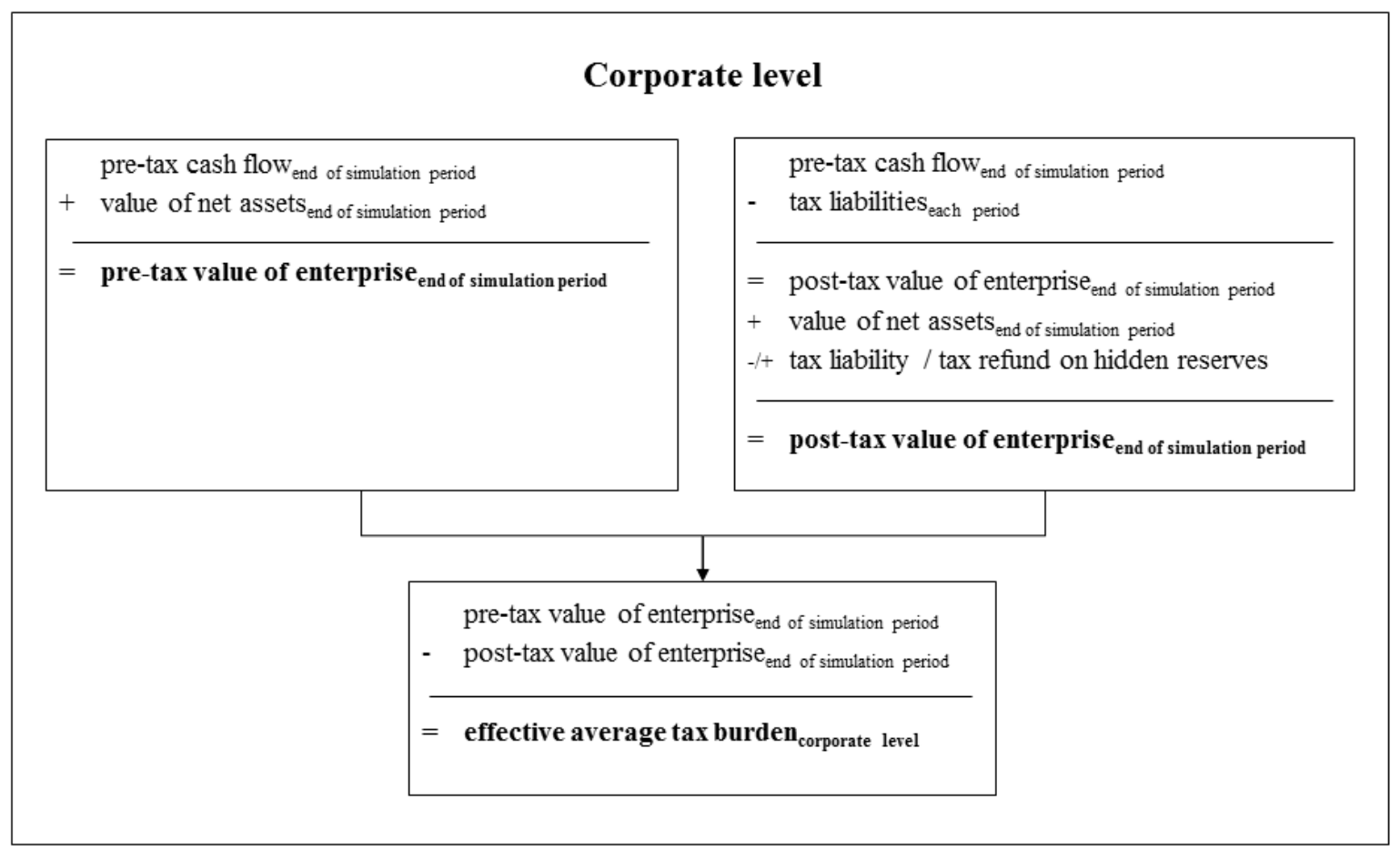

The actual tax burden on the corporate level is calculated by subtracting the post-tax value of the company at the end of the simulation period from the pre-tax value (see Figure 3). The former equals the sum of the pre-tax cash flows and the value of the net assets of the company at the end of the simulation period. The post-tax value of the enterprise is based on the pre-tax cash flow less the tax liabilities from each period. Moreover, the value of the net assets at the end of the simulation period reduced by potential tax liabilities on hidden reserves needs to be added to arrive at the post-tax value of the company. The effective tax burden is given as an absolute number.

\footnotetext{
${ }^{22}$ The following provisions relating to the tax base are considered: depreciation schemes (pool vs. individual depreciation schemes; depreciation periods), inventory valuation (LIFO, FIFO or weighted average cost method), capitalization of R\&D costs, employee pension schemes (i.e., deductibility of pension costs, contributions to pension funds), thin capitalization rules, earnings stripping rules, notional interest deductions, provisions for bad debt and guarantee accruals, avoidance mechanisms for double taxation on foreign-source income (i.e., exemption method, tax credit, deduction of foreign taxes), non-deductible items and loss relief rules (carry-back, carry-forward). Additionally, non-profit taxes with special bases can be included (e.g., real estate tax, payroll tax).
} 
Table 2 displays the currently available SME tax incentives that are included in the determination of effective tax burdens with the European Tax Analyzer. Calculations are made for all 28 Member States of the European Union. Due to the model assumptions and the characteristics of the model companies, not all regimes can be modelled. Since effective tax burdens are given as absolute numbers, the values calculated for the four model enterprises (micro, small medium-sized and large) cannot directly be compared with each other. Instead, the effective tax burden is calculated twice for each SME category: once according to the provisions applying to large enterprises and once allowing for SME tax incentives. The difference between both values represents the reduction induced by SME tax incentives. Comparing the relative reliefs for different size classes then enables a comparison of effect sizes.

Further SME incentives such as preferential loss offset rules and special provisions on carry forwards and refunds of excess reliefs provided by tax incentives usually do not show in the effective tax burdens due to the underlying assumptions about the model companies' economic development. Moreover, purely administrative reliefs cannot be captured and shareholder-level incentives are neglected. ${ }^{23}$ SME incentives limited to overly specific assets, activities or regions (e.g., for energy rationalization, education and training expenses or investments in special economic zones) are not considered either because they do not apply to the majority of SMEs or their implementation would require a more detailed specification of the model company that is not feasible with the AMADEUS data at hand.

\footnotetext{
${ }^{23}$ Shareholder taxation and the effect of incentives on this level of taxation are generally difficult to capture adequately because of the heterogeneity of shareholders. While investment funds and corporate investors are oftentimes exempt from the taxation of their proceeds, individuals are mostly not. However, even among them, taxation may vary significantly depending on the classification of proceeds as either capital income or business income. In addition, the vast majority of incentives are provided on the corporate level and previous analyses have found only small effects of incentives on the shareholder level. See European Commission (2015b) pp. 84 ff.
} 
Table 2: Implementation of available SME tax incentives (European Tax Analyzer)

\begin{tabular}{|c|c|c|c|}
\hline \multirow{2}{*}{ Country } & \multirow{2}{*}{ Incentive } & \multicolumn{2}{|r|}{ Implementation } \\
\hline & & Yes/no & Notes \\
\hline Austria & - & - & - \\
\hline Belgium & $\begin{array}{l}\text { progressive CIT rate } \\
\text { exemption from fairness tax } \\
\text { exemption from capital gains tax } \\
\text { increased notional interest deduction } \\
\text { investment allowance }(10.5 \%) \\
\text { investment allowance }(4 \%) \\
\text { investment allowance for safety measures } \\
\text { accelerated depreciation }\end{array}$ & $\begin{array}{l}\text { yes } \\
\text { no } \\
\text { no } \\
\text { yes } \\
\text { no } \\
\text { no } \\
\text { no } \\
\text { no }\end{array}$ & $\begin{array}{l}\text { applies to each model SME } \\
\text { does not apply to model companies (only corporate level considered) } \\
\text { does not apply to model companies (no capital gains) } \\
\text { applies to micro and small model companies } \\
\text { does not apply to model companies (only for non-corporate entities) } \\
\text { not applicable in combination with notional interest deduction } \\
\text { not implemented due to limited application (only safety measures) } \\
\text { not implemented due to model restrictions and immateriality }\end{array}$ \\
\hline Bulgaria & - & - & - \\
\hline Croatia & $\begin{array}{l}\text { reduced CIT rate for new investments } \\
\text { investment allowance for costs of education and training }\end{array}$ & no & $\begin{array}{l}\text { not implemented due to limited application (only new ventures and major } \\
\text { business extensions; similar regime for all companies in place) } \\
\text { not implemented due to model restrictions and immateriality }\end{array}$ \\
\hline Cyprus & - & - & - \\
\hline Czech Republic & - & - & - \\
\hline Denmark & - & - & - \\
\hline Estonia & - & - & - \\
\hline Finland & - & - & - \\
\hline France & $\begin{array}{l}\text { reduced CIT rate } \\
\text { exemption from surcharge on income tax liability }(3.3 \%) \\
\text { exemption from surcharge on income tax liability }(10.7 \%) \\
\text { progressive local business tax } \\
\text { exemption from local business tax } \\
\text { progressive minimum taxation } \\
\text { tax credit for newly acquired assets (based on depreciation) } \\
\text { tax credit for newly acquired assets (based on acquisition costs) } \\
\text { tax credit for newly hired employees }\end{array}$ & $\begin{array}{l}\text { yes } \\
\text { yes } \\
\text { yes } \\
\text { yes } \\
\text { no } \\
\text { no } \\
\text { yes } \\
\text { no } \\
\text { no }\end{array}$ & $\begin{array}{l}\text { applies to micro and small model companies } \\
\text { applies to micro and small model companies } \\
\text { applies to each model SME } \\
\text { effect not displayed because scheme is part of the general tax code } \\
\text { does not apply to model companies (exceed eligibility threshold) } \\
\text { does not apply to model companies (exceed eligibility threshold) } \\
\text { applies to each model SME } \\
\text { not implemented due to limited application (regional) } \\
\text { not implemented due to model restrictions }\end{array}$ \\
\hline Germany & $\begin{array}{l}\text { accelerated depreciation } \\
\text { investment allowance } \\
\text { exemption from local business tax }(€ 24,500)\end{array}$ & $\begin{array}{l}\text { yes } \\
\text { no } \\
\text { no }\end{array}$ & $\begin{array}{l}\text { applies to micro model company } \\
\text { not implemented due to model restrictions } \\
\text { does not apply to model companies }\end{array}$ \\
\hline Greece & - & - & - \\
\hline
\end{tabular}




\begin{tabular}{|c|c|c|c|}
\hline \multirow{2}{*}{ Country } & \multirow{2}{*}{ Incentive } & \multicolumn{2}{|r|}{ Implementation } \\
\hline & & Yes/no & \begin{tabular}{|c|} 
\\
Notes \\
\end{tabular} \\
\hline Hungary & $\begin{array}{l}\text { progressive CIT rate } \\
\text { exemption from local business tax } \\
\text { exemption from innovation tax } \\
\text { tax credit for interest payments } \\
\text { investment allowances for new employees and disabled employees } \\
\text { investment allowance for certain business assets } \\
\text { accelerated depreciation } \\
\text { alternative regimes (simplified entrepreneurial tax, small business } \\
\text { tax, itemized tax on small businesses) }\end{array}$ & $\begin{array}{l}\text { yes } \\
\text { yes } \\
\text { yes } \\
\text { yes } \\
\text { no } \\
\text { no } \\
\text { no } \\
\text { no }\end{array}$ & $\begin{array}{l}\text { effect not displayed because scheme is part of the general tax code } \\
\text { applies to micro and small model companies (municipalities determine } \\
\text { eligibility) } \\
\text { applies to micro and small model companies } \\
\text { applies to each model SME } \\
\text { not implemented due to model restrictions } \\
\text { not implemented due to model restrictions } \\
\text { not implemented due to limited application (regional) } \\
\text { not implemented due to model restrictions }\end{array}$ \\
\hline Ireland & reduced CIT rate for new companies & no & not implemented due to limited application (only new companies) \\
\hline Italy & - & - & - \\
\hline Latvia & $\begin{array}{l}\text { progressive CIT rate } \\
\text { tax credit } \\
\text { micro enterprise tax }\end{array}$ & $\begin{array}{l}\text { no } \\
\text { no } \\
\text { no }\end{array}$ & $\begin{array}{l}\text { does not apply to model companies (exceed eligibility threshold) } \\
\text { not implemented due to limited application (regional) } \\
\text { does not apply to model companies (exceed eligibility threshold) }\end{array}$ \\
\hline Lithuania & $\begin{array}{l}\text { reduced CIT rate } \\
\text { free depreciation } \\
\text { unrestricted loss carry forward }\end{array}$ & $\begin{array}{l}\text { yes } \\
\text { yes } \\
\text { no }\end{array}$ & $\begin{array}{l}\text { applies to micro model company } \\
\text { applies to micro model company } \\
\text { does not apply to model companies (no losses) }\end{array}$ \\
\hline Luxembourg & $\begin{array}{l}\text { reduced CIT rate } \\
\text { exemption from local business tax }(€ 17,500)\end{array}$ & $\begin{array}{c}\text { no } \\
\text { yes }\end{array}$ & $\begin{array}{l}\text { does not apply to model companies (exceed eligibility threshold) } \\
\text { effect not displayed because scheme is part of the general tax code }\end{array}$ \\
\hline Malta & $\begin{array}{l}\text { tax credit (general) } \\
\text { tax credit for R\&D } \\
\text { tax credit for new ventures and major business extensions }\end{array}$ & $\begin{array}{l}\text { yes } \\
\text { no } \\
\text { no }\end{array}$ & $\begin{array}{l}\text { applies to micro and small model companies } \\
\text { not implemented due to limited application (only R\&D) } \\
\text { not implemented due to limited application (only new ventures and major } \\
\text { business extensions and only certain activities) }\end{array}$ \\
\hline Netherlands & $\begin{array}{l}\text { progressive CIT rate } \\
\text { investment allowance } \\
\text { lump-sum deduction for } \mathrm{R} \& \mathrm{D}\end{array}$ & $\begin{array}{l}\text { yes } \\
\text { yes } \\
\text { no }\end{array}$ & $\begin{array}{l}\text { effect not displayed because scheme is part of the general tax code } \\
\text { effect not displayed because scheme is part of the general tax code } \\
\text { does not apply to model companies (only for individual entrepreneurs) }\end{array}$ \\
\hline Poland & $\begin{array}{l}\text { immediate depreciation } \\
\text { tax credit for innovative technology } \\
\text { investment allowance for new assets / new employees }\end{array}$ & $\begin{array}{l}\text { yes } \\
\text { no } \\
\text { no }\end{array}$ & $\begin{array}{l}\text { applies to micro model company } \\
\text { not implemented due to model restrictions } \\
\text { not implemented due to limited application (regional) }\end{array}$ \\
\hline Portugal & $\begin{array}{l}\text { reduced CIT rate } \\
\text { progressive surcharge } \\
\text { exemption from corporate income tax for new companies }\end{array}$ & $\begin{array}{l}\text { yes } \\
\text { yes } \\
\text { no }\end{array}$ & $\begin{array}{l}\text { applies to each model SME } \\
\text { effect not displayed because scheme is part of the general tax code } \\
\text { does not apply to model companies (only if simplified regime applied) }\end{array}$ \\
\hline
\end{tabular}




\begin{tabular}{|c|c|c|c|}
\hline \multirow{2}{*}{ Country } & \multirow{2}{*}{ Incentive } & \multicolumn{2}{|r|}{ Implementation } \\
\hline & & Yes/no & Notes \\
\hline Portugal (ctd.) & $\begin{array}{l}\text { tax credit for } \mathrm{R} \& \mathrm{D} \\
\text { tax credit for reinvested retained earnings } \\
\text { notional interest deduction }\end{array}$ & $\begin{array}{l}\text { no } \\
\text { no } \\
\text { yes }\end{array}$ & $\begin{array}{l}\text { not implemented due to limited application (only R\&D) } \\
\text { not implemented due to model restrictions } \\
\text { applies to all model SMEs but only to initial deposits and capital increases }\end{array}$ \\
\hline Romania & turnover tax & no & does not apply to model companies (exceed eligibility threshold) \\
\hline Slovakia & - & - & - \\
\hline Slovenia & - & - & - \\
\hline Spain & $\begin{array}{l}\text { reduced CIT rates } \\
\text { reduced CIT rate (Basque regions) } \\
\text { exemption from local business tax } \\
\text { tax credit for newly hired employees ( } € 3,000 \text { per employee) } \\
\text { tax credit for newly hired employees ( } 50 \% \text { of outstanding } \\
\text { unemployment payments) } \\
\text { accelerated depreciation }\end{array}$ & $\begin{array}{l}\text { yes } \\
\text { no } \\
\text { yes } \\
\text { yes } \\
\text { no } \\
\text { yes }\end{array}$ & $\begin{array}{l}\text { applies to each model SME (more generous for micro and small companies) } \\
\text { not implemented due to limited application (regional) } \\
\text { applies to micro model company } \\
\text { applies to micro and small model companies; only applies for new employees } \\
\text { (model assumes employees to be eligible in first year) } \\
\text { not implemented due to model restrictions } \\
\text { applies to micro and small model companies }\end{array}$ \\
\hline Sweden & - & - & - \\
\hline United Kingdom & $\begin{array}{l}\text { progressive CIT rate } \\
\text { investment allowance for } R \& D\end{array}$ & $\begin{array}{l}\text { no } \\
\text { no }\end{array}$ & $\begin{array}{l}\text { not implemented due to limited application (only oil and gas companies) } \\
\text { not implemented due to limited application (only R\&D) }\end{array}$ \\
\hline
\end{tabular}




\section{3}

\section{Effective Tax Burdens by Size Class}

Table 3 shows the effective tax burdens for micro, small, medium-sized and large companies as well as the reduction of the tax burden induced by SME tax incentives. First, the lack of significant reliefs for medium-sized entities in all but three countries (France, Hungary, and Portugal) is noticeable. The reduction of their tax burden does not exceed $2 \%$ anywhere. The average relief amounts to $0.1 \%(0.86 \%$ if only considering the countries providing incentives for medium-sized entities). Whatever arguments justify the use of SME tax incentives for policy-makers, they do not seem to apply to medium-sized enterprises, i.e., firms with 50 to 250 employees and an annual turnover between $€ 10$ million and $€ 50$ million. ${ }^{24}$ As there are no significant reliefs for medium-sized companies, the ranking of the respective tax burdens is also a good estimate of the general levels of company taxation in the sample countries (see Figure 4). Clearly, substantial differences occur. France, for example, features a tax burden that is more than four times as high as the burden imposed on Bulgarian firms. In general, enterprises in Eastern European countries are subject to relatively low levels of taxation whereas the Western and the Southern European countries can mostly be found at the other end of the spectrum.

Figure 4: Effective tax burden of medium-sized companies (European Tax Analyzer)

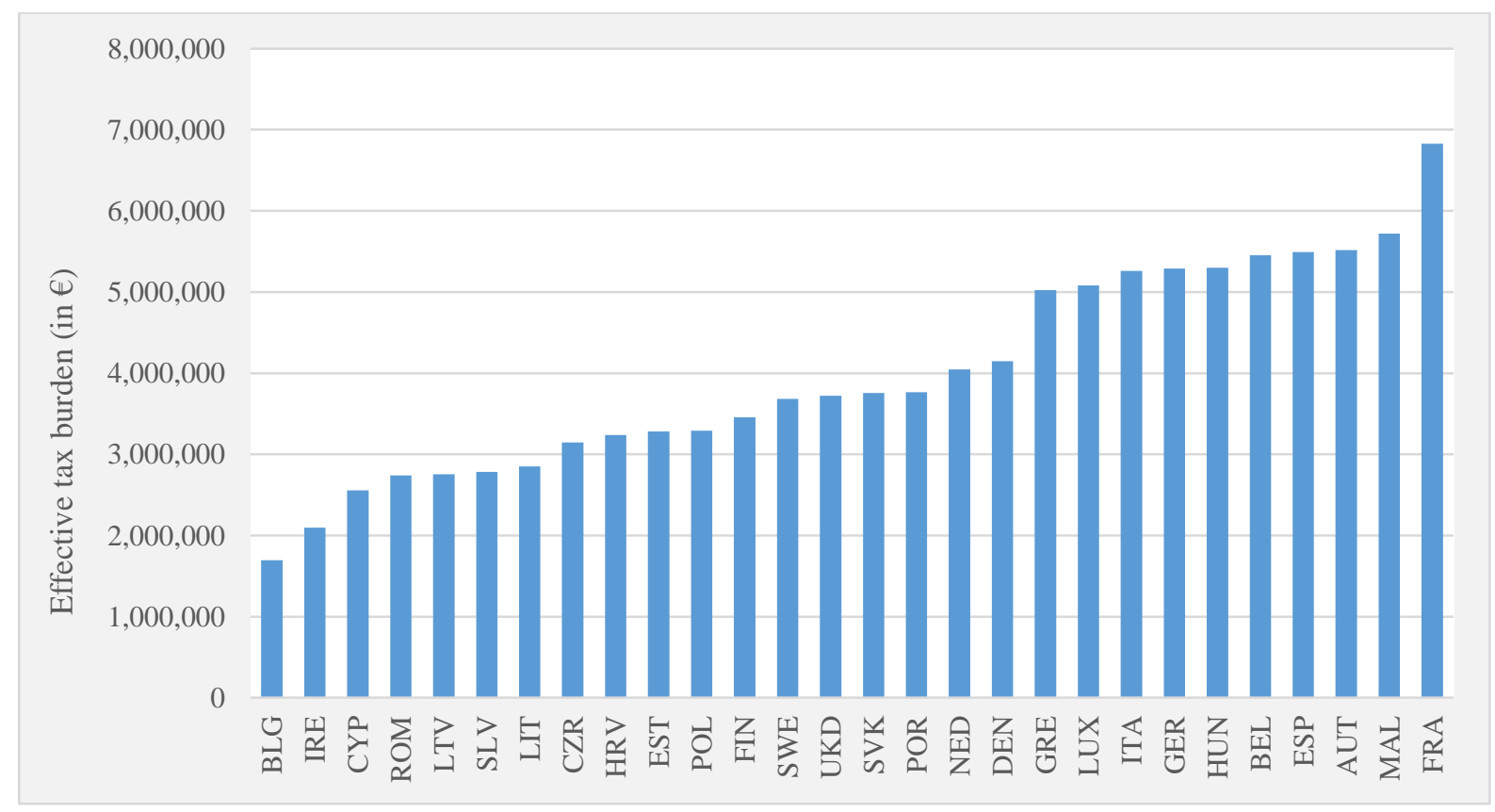

\footnotetext{
${ }^{24}$ The definition of medium-sized enterprises given by the European Commission also demands a balance sheet total between $€ 10$ million and $€ 43$ million. The balance sheet total is rarely used as an eligibility criterion for SME tax incentives, though. See European Commission (2015c) pp. $10 \mathrm{f}$.
} 
For small enterprises, the number of countries providing reliefs increases to eight (only taking into account those considered in the European Tax Analyzer). While half of them provide substantial reliefs (France, Hungary, Spain), incentives in the other half feature very modest effects (Belgium, Malta, Portugal). The average relief amounts to $3.50 \%$ of the tax liability as determined for the rules applying for large taxpayers $(15.17 \%$ if only considering countries effectively providing incentives for small companies).

By far the most generous regime exists in Hungary where the tax burden is reduced by more than $60 \%$ compared to large enterprise rules. The reduction is mainly driven by exemptions from the local business tax and the so-called innovation tax which are only available for small and micro companies. ${ }^{25}$ Municipalities, however, can decide against granting the exemption. Hence, businesses do not benefit everywhere in Hungary. In addition to the exemptions, small and micro companies may also be eligible for three alternative regimes that completely replace ordinary income taxation based on accrual accounts (the simplified entrepreneurial tax, the small business tax and the itemized tax on small businesses). These regimes may induce even larger reliefs. The case of Hungary exemplifies two major concerns with SME tax incentives. Firstly, if companies are not eligible for lucrative incentives as soon as they outgrow the small business category, generous reliefs provide a huge discouragement from growth or a huge encouragement of misreporting taxable income and business size. Total exemptions from certain taxes are especially prone to this problem. They create notches at which not only the marginal but also the average tax rate jumps. This creates stronger distortions of economic decision-making than so-called kinks where only the marginal tax treatment changes. ${ }^{26}$ The availability of a multitude of regimes and incentives ${ }^{27}$ is the second concern with Hungary. In the face of several options, entrepreneurs may experience difficulties in predicting the overall available relief and choosing the regime actually minimizing the tax burden. A substantial part of the tax savings may thus be offset by the additional costs of tax planning and tax compliance. As mentioned above, the imbalance of the relief and the costs of planning and complying becomes even more of a concern for less generous regimes, e.g., in Belgium.

\footnotetext{
${ }^{25}$ Both taxes are levied on the difference of sales and certain costs directly attributable to sales.

${ }^{26}$ See Slemrod (2013) pp. 259 ff., for a detailed differentiation of kinks and notches in the tax system. Section 5.1 also includes a detailed discussion of problems emanating from jumps in the tax system.

${ }^{27}$ Besides the alternative regimes, Hungary also offers several tax credits, allowances and depreciation schemes. See the country report in Annex 1.
} 
Table 3: Effective tax burden by size class in the EU in thsd. $€$ (European Tax Analyzer)

\begin{tabular}{|c|c|c|c|c|c|c|c|c|c|c|}
\hline \multirow{2}{*}{ Country } & \multirow{2}{*}{$\begin{array}{c}\text { Large } \\
\text { enterprise }\end{array}$} & \multicolumn{3}{|c|}{ Medium-sized enterprise } & \multicolumn{3}{|c|}{ Small enterprise } & \multicolumn{3}{|c|}{ Micro enterprise } \\
\hline & & No incentive & Incentives & Reduction & No incentive & Incentives & Reduction & No incentive & Incentives & Reduction \\
\hline AUT & $51,091.3$ & $5,519.0$ & $5,519.0$ & $0.00 \%$ & $1,506.9$ & $1,506.9$ & $0.00 \%$ & 275.9 & 275.9 & $0.00 \%$ \\
\hline BEL & $54,151.9$ & $5,451.7$ & $5,451.7$ & $0.00 \%$ & $1,533.6$ & $1,497.3$ & $-2.37 \%$ & 298.8 & 262.5 & $-12.15 \%$ \\
\hline BLG & $16,996.3$ & $1,693.0$ & $1,693.0$ & $0.00 \%$ & 485.4 & 485.4 & $0.00 \%$ & 94.2 & 94.2 & $0.00 \%$ \\
\hline HRV & $32,459.7$ & $3,240.3$ & $3,240.3$ & $0.00 \%$ & 933.7 & 933.7 & $0.00 \%$ & 178.6 & 178.6 & $0.00 \%$ \\
\hline CYP & $24,595.5$ & $2,554.2$ & $2,554.2$ & $0.00 \%$ & 697.2 & 697.2 & $0.00 \%$ & 127.5 & 127.5 & $0.00 \%$ \\
\hline CZR & $31,522.9$ & $3,145.3$ & $3,145.3$ & $0.00 \%$ & 900.3 & 900.3 & $0.00 \%$ & 174.1 & 174.1 & $0.00 \%$ \\
\hline DEN & $41,355.1$ & $4,149.9$ & $4,149.9$ & $0.00 \%$ & $1,185.9$ & $1,185.9$ & $0.00 \%$ & 234.0 & 234.0 & $0.00 \%$ \\
\hline EST & $32,964.6$ & $3,281.5$ & $3,281.5$ & $0.00 \%$ & 936.3 & 936.3 & $0.00 \%$ & 182.4 & 182.4 & $0.00 \%$ \\
\hline FIN & $34,494.8$ & $3,455.9$ & $3,455.9$ & $0.00 \%$ & 988.4 & 988.4 & $0.00 \%$ & 192.9 & 192.9 & $0.00 \%$ \\
\hline FRA & $75,909.9$ & $6,935.9$ & $6,828.8$ & $-1.54 \%$ & $1,736.9$ & $1,641.4$ & $-5.50 \%$ & 310.4 & 228.7 & $-26.31 \%$ \\
\hline GER & $53,577.4$ & $5,291.7$ & $5,291.7$ & $0.00 \%$ & $1,489.3$ & $1,489.3$ & $0.00 \%$ & 288.7 & 287.6 & $-0.40 \%$ \\
\hline GRE & $49,627.8$ & $5,023.7$ & $5,023.7$ & $0.00 \%$ & $1,463.0$ & $1,463.0$ & $0.00 \%$ & 288.8 & 288.8 & $0.00 \%$ \\
\hline HUN & $63,671.4$ & $5,322.4$ & $5,301.1$ & $-0.40 \%$ & $1,335.6$ & 517.0 & $-61.29 \%$ & 170.9 & 105.7 & $-38.17 \%$ \\
\hline IRE & $21,005.3$ & $2,095.3$ & $2,095.3$ & $0.00 \%$ & 600.2 & 600.2 & $0.00 \%$ & 116.9 & 116.9 & $0.00 \%$ \\
\hline ITA & $52,459.4$ & $5,261.3$ & $5,261.3$ & $0.00 \%$ & $1,489.0$ & $1,489.0$ & $0.00 \%$ & 289.5 & 289.5 & $0.00 \%$ \\
\hline LTV & $27,372.4$ & $2,755.5$ & $2,755.5$ & $0.00 \%$ & 786.6 & 786.6 & $0.00 \%$ & 156.3 & 156.3 & $0.00 \%$ \\
\hline LIT & $28,234.5$ & $2,851.2$ & $2,851.2$ & $0.00 \%$ & 813.3 & 813.3 & $0.00 \%$ & 163.3 & 105.4 & $-35.42 \%$ \\
\hline LUX & $50,949.7$ & $5,081.8$ & $5,081.8$ & $0.00 \%$ & $1,459.5$ & $1,459.5$ & $0.00 \%$ & 275.1 & 275.1 & $0.00 \%$ \\
\hline MAL & $57,446.5$ & $5,721.9$ & $5,721.9$ & $0.00 \%$ & $1,637.6$ & $1,605.7$ & $-1.95 \%$ & 316.2 & 284.5 & $-10.04 \%$ \\
\hline NED & $41,482.8$ & $4,046.4$ & $4,046.4$ & $0.00 \%$ & $1,088.0$ & $1,088.0$ & $0.00 \%$ & 186.1 & 186.1 & $0.00 \%$ \\
\hline POL & $32,904.4$ & $3,293.0$ & $3,293.0$ & $0.00 \%$ & 941.8 & 941.8 & $0.00 \%$ & 185.0 & 184.6 & $-0.20 \%$ \\
\hline POR & $43,562.7$ & $3,796.6$ & $3,767.1$ & $-0.78 \%$ & $1,071.6$ & $1,057.4$ & $-1.33 \%$ & 208.2 & 200.1 & $-3.87 \%$ \\
\hline ROM & $27,385.8$ & $2,742.0$ & $2,742.0$ & $0.00 \%$ & 784.9 & 784.9 & $0.00 \%$ & 153.9 & 153.9 & $0.00 \%$ \\
\hline SVK & $37,577.1$ & $3,758.1$ & $3,758.1$ & $0.00 \%$ & $1,075.1$ & $1,075.1$ & $0.00 \%$ & 210.3 & 210.3 & $0.00 \%$ \\
\hline SLV & $27,954.0$ & $2,782.2$ & $2,782.2$ & $0.00 \%$ & 797.2 & 797.2 & $0.00 \%$ & 154.2 & 154.2 & $0.00 \%$ \\
\hline ESP & $55,230.1$ & $5,494.4$ & $5,494.4$ & $0.00 \%$ & $1,572.0$ & $1,170.5$ & $-25.54 \%$ & 305.0 & 166.0 & $-45.56 \%$ \\
\hline
\end{tabular}




\begin{tabular}{|c|c|c|c|c|c|c|c|c|c|c|}
\hline \multirow{2}{*}{ Country } & \multirow{2}{*}{$\begin{array}{c}\text { Large } \\
\text { enterprise }\end{array}$} & \multicolumn{3}{|c|}{ Medium-sized enterprise } & \multicolumn{3}{|c|}{ Small enterprise } & \multicolumn{3}{|c|}{ Micro enterprise } \\
\hline & & No incentive & Incentives & Reduction & No incentive & Incentives & Reduction & No incentive & Incentives & Reduction \\
\hline SWE & $36,867.0$ & $3,681.7$ & $3,681.7$ & $0.00 \%$ & $1,054.1$ & $1,054.1$ & $0.00 \%$ & 204.9 & 204.9 & $0.00 \%$ \\
\hline UKD & $36,942.8$ & $3,720.9$ & $3,720.9$ & $0.00 \%$ & $1,062.1$ & $1,062.1$ & $0.00 \%$ & 212.5 & 212.5 & $0.00 \%$ \\
\hline
\end{tabular}


For micro companies, available SME tax incentives are even more numerous and more generous than for small entities. 10 out of 28 countries provide measures that are implemented in the calculations and the average relief per country increases from $3.50 \%$ to $6.15 \%$ of the effective tax burden. Except for Hungary, all countries with SME tax incentives in place offer more generous reliefs to micro than to small enterprises (see Figure 5). Apparently, policy-makers perceive the need for tax incentives to decrease in firm size across all three subcategories of the SME sector. Countries providing especially generous regimes for micro companies include Spain, Hungary, Lithuania, Belgium, France and Malta. Except for Lithuania, each of these countries features a comparatively high tax burden for large corporations. It seems, the higher the general tax burden, the more likely a country is to provide relief for small and micro businesses. Interestingly, this may evoke the problem of severely disadvantaging the enterprises which are just too big to be eligible for SME incentives but not big enough to lower the overall tax burden by engaging in international tax planning.

Figure 5: Effect of SME tax incentives (European Tax Analyzer)

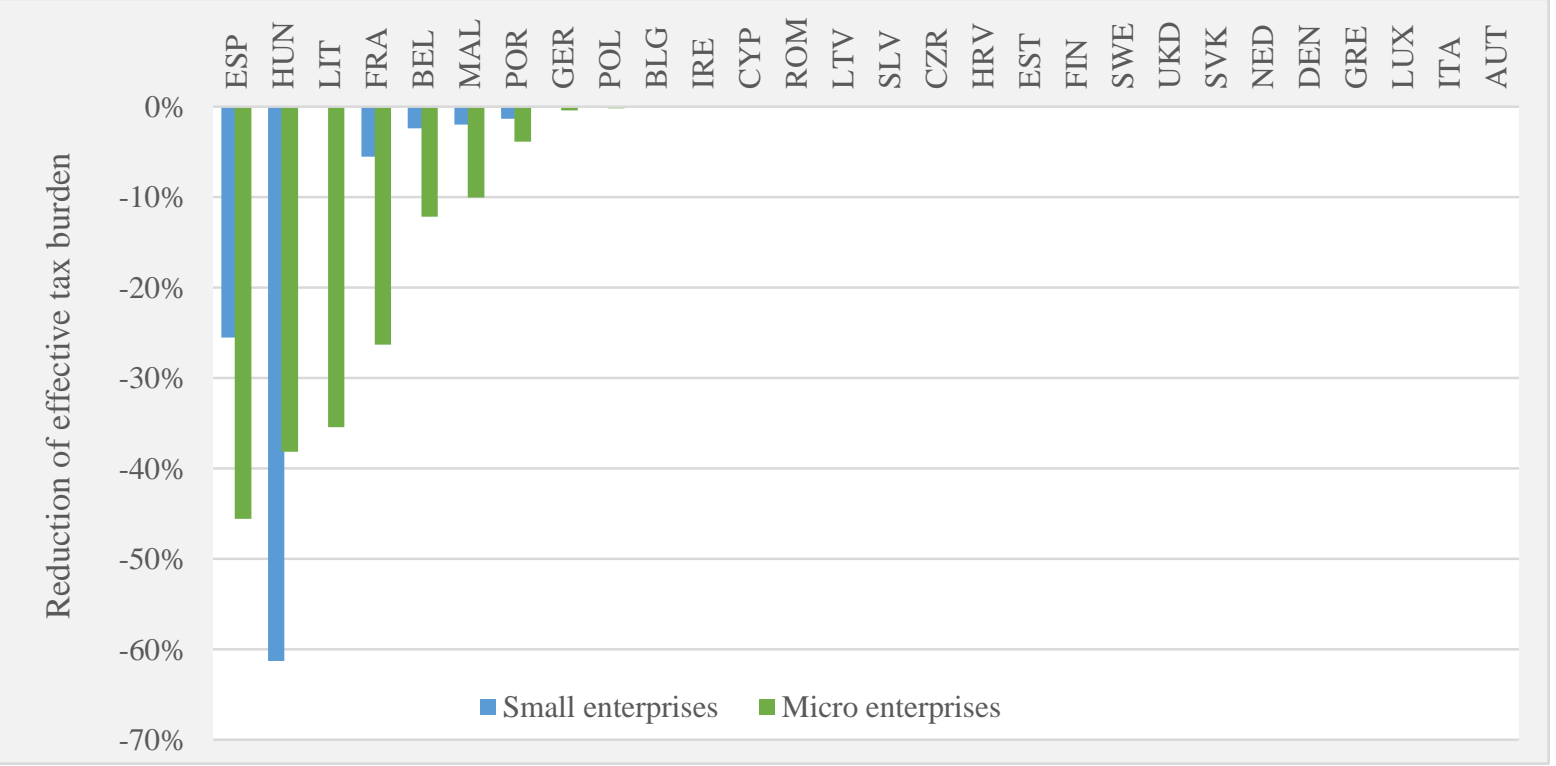

\subsection{Comparison of Incentive Types}

Table 4 displays the reduction in tax burdens induced by three different types of SME tax incentives - incentives relating to the tax base (i.e., special depreciation schemes and investment allowances), tax credits and special tax rates. The comparison shows special tax rates to be the most common as well as the most generous type of tax incentive. The average relief provided by reduced tax rates amounts to $15.17 \%$ and $16.60 \%$ of the effective 
tax burden for small and micro companies, respectively. This is three times as high as the average reduction induced by tax credits (for small entities even five times as high). The relief of measures relating to the tax base appears negligible at less than $1 \%$ on average. Altogether, only one input-based tax incentive reduces the tax burden of an average micro company by more than $10 \%$ (Malta) whereas special tax rates regularly induce double-digit reliefs.

There are several explanations for these findings. First of all, a number of inputbased incentives cannot be implemented into the European Tax Analyzer because they relate to very specific circumstances that are not met by the model companies under consideration. While the omissions may amplify the gap between the effects of the different forms of relief, they are not the main driver as is evidenced by the lower average effect per incentive $(4.11 \%$ vs. $13.06 \%$ for small companies and $5.55 \%$ vs. $20 \%$ for micro companies, respectively). Instead the basic design and the intentions behind the incentives appear to be crucial. By design, special depreciation schemes such as in Germany and Lithuania do not change the overall tax liability but only the timing of tax payments. The reduction of the tax burden can thus be traced back to a mere interest advantage emanating from deferred tax payments. ${ }^{28}$ Tax allowances and tax credits theoretically allow for more generous reliefs as they reduce the overall sum of tax payments, either directly (tax credits) or indirectly (investment allowances). The reliefs, however, are modest as well. Partly, this is caused by the high profitability that is assumed for the model companies. For low-profit enterprises, the actual impact of input-based incentives may be larger than indicated by the European Tax Analyzer because the reduction of taxable income (of the tax liability if tax credits are considered) accounts for a larger share of the overall tax base (tax liability) for them. The modest relief, however, could also indicate other purposes than a mere reduction of the tax burden. The two allowances in Belgium and Portugal, for example, support equity financing. It seems their primary purpose is securing improved financing neutrality. The tax credits in Malta and Spain both relate to job creation and take employment or personnel costs as calculation bases. So the reduction of wage costs apparently is the aim of these regimes. Lastly, the abovementioned depreciation schemes may not substantially reduce the sum of tax payments but they do

\footnotetext{
${ }^{28}$ The interest advantage naturally increases in the applicable interest rate. The calculations at hand assume an interest rate of $1.1 \%$, which is evidence of the low-interest period financial markets have experienced in the past few years. In times of higher interest rates, special depreciation schemes may thus provide more generous reliefs.
} 
facilitate the financing of new investments, thereby addressing SMEs' problems in obtaining capital in early investment stages. ${ }^{29}$

Table 4: Effect of SME tax incentives by incentive type (European Tax Analyzer)

\begin{tabular}{|l|rrr|r|rrr|r|}
\hline \multirow{2}{*}{ Country } & \multicolumn{4}{|c|}{ Small enterprise } & \multicolumn{3}{c|}{ Micro enterprise } \\
\cline { 2 - 10 } & Tax base & Tax credit & Tax rate & \multicolumn{1}{c|}{ Total } & Tax base & Tax credit & Tax rate & \multicolumn{1}{c|}{ Total } \\
\hline BEL & $-1.85 \%$ & $0.00 \%$ & $-0.47 \%$ & $-2.37 \%$ & $-2.03 \%$ & $0.00 \%$ & $-10.10 \%$ & $-12.15 \%$ \\
FRA & $0.00 \%$ & $-0.61 \%$ & $-4.89 \%$ & $-5.50 \%$ & $0.00 \%$ & $-0.51 \%$ & $-25.81 \%$ & $-26.31 \%$ \\
GER & $0.00 \%$ & $0.00 \%$ & $0.00 \%$ & $0.00 \%$ & $-0.40 \%$ & $0.00 \%$ & $0.00 \%$ & $-0.40 \%$ \\
HUN & $0.00 \%$ & $-1.48 \%$ & $-59.70 \%$ & $-61.29 \%$ & $0.00 \%$ & $0.00 \%$ & $-38.17 \%$ & $-38.17 \%$ \\
LIT & $0.00 \%$ & $0.00 \%$ & $0.00 \%$ & $0.00 \%$ & $-1.95 \%$ & $0.00 \%$ & $-53.05 \%$ & $-35.42 \%$ \\
LUX & $0.00 \%$ & $0.00 \%$ & $0.00 \%$ & $0.00 \%$ & $0.00 \%$ & $0.00 \%$ & $0.00 \%$ & $0.00 \%$ \\
MAL & $0.00 \%$ & $-1.95 \%$ & $0.00 \%$ & $-1.95 \%$ & $0.00 \%$ & $-10.04 \%$ & $0.00 \%$ & $-10.04 \%$ \\
POL & $0.00 \%$ & $0.00 \%$ & $0.00 \%$ & $0.00 \%$ & $-0.20 \%$ & $0.00 \%$ & $0.00 \%$ & $-0.20 \%$ \\
POR & $-0.75 \%$ & $0.00 \%$ & $-0.58 \%$ & $-1.33 \%$ & $-0.88 \%$ & $0.00 \%$ & $-2.99 \%$ & $-3.87 \%$ \\
ESP & $-0.24 \%$ & $-8.28 \%$ & $-17.56 \%$ & $-25.54 \%$ & $-0.38 \%$ & $-6.10 \%$ & $-39.15 \%$ & $-45.56 \%$ \\
\hline \hline Mean & $\mathbf{- 0 , 9 4 \%}$ & $\mathbf{- 4 , 1 1 \%}$ & $\mathbf{- 1 3 , 0 6 \%}$ & $\mathbf{- 1 5 , 1 7 \%}$ & $\mathbf{- 0 , 9 7 \%}$ & $\mathbf{- 5 , 5 5 \%}$ & $\mathbf{- 2 0 , 0 0 \%}$ & $\mathbf{- 1 6 , 6 0 \%}$ \\
\hline
\end{tabular}

Notes: Table 14 only covers countries providing SME tax incentives that can be implemented with the European Tax Analyzer. The average reduction for each type of incentive is calculated on a per-incentive basis, i.e., it only includes those countries providing the respective type of incentive.

Altogether, it seems that input-based tax incentives address very specific issues and that they focus on SMEs because SMEs are considered to be especially affected by the respective issues (e.g., financing constraints ${ }^{30}$ ) or because they are perceived to be crucial in solving the issues (e.g., unemployment, insufficient R\&D activity ${ }^{31}$ ). Additionally, EU legislation may force Member States to limit tax incentives to small and medium-sized enterprises. ${ }^{32}$ Targeting specific issues, however, oftentimes requires additional eligibility criteria so that a multitude of firms and investments are excluded (e.g., an increase in employment, a restriction to R\&D-specific investments or a restriction to newly founded companies). This shows in comparatively small average reliefs in the calculations. Eligibility criteria for preferential SME tax rates, in contrast, usually only include firm size. They appear to be the instrument of choice if SMEs as a whole are intended to be relieved - whatever the motivation behind this kind of incentive may be.

\footnotetext{
${ }^{29}$ For a scheme allowing immediate depreciation, the share of acquisition costs being contributed in the form of reduced tax payments in the acquisition year is (almost) equal to the statutory tax rate. In Spain, for example, immediate depreciation would thus reduce the capital requirements for the acquisition of a new machine by $25 \%$.

${ }^{30}$ See Section 4.1.4 for a comprehensive discussion of SMEs' financing constraints.

${ }^{31}$ See Section 4.1.2 for a comprehensive discussion of SMEs' role in job creation.

${ }^{32}$ The European Commission restricts the provision of direct and indirect state aid to selected (groups of) enterprises in order to prevent the distortion of competition. SMEs are subject to less restrictive regulation. See European Commission (2009) pp. $9 \mathrm{ff}$.
} 
The interplay of input-based incentives and special tax rates is another aspect worth examining. Four of the 10 countries with SME tax incentives provide several measures at the same time (only counting the incentives being implemented in the European Tax Analyzer). An especially interesting constellation occurs in Lithuania where the overall reduction of the tax burden for a micro company amounts to $35.42 \%$. If the model company only took advantage of the special tax rate and deferred the option to immediately depreciate newly acquired fixed assets, the tax savings would be much higher (53.05\% of the tax burden). The counterintuitive result occurs because immediate expensing of acquisition costs creates hidden reserves that are realized at the end of the sample period of 10 years. As a consequence, the income in the last period exceeds the eligibility threshold for the preferential tax rate and the model company incurs a higher tax burden than a similarly successful company with more consistent taxable earnings. This phenomenon, of course, is at least partly the result of the model assumptions, i.e., the final liquidation. However, it also shows that one incentive can impede the effectiveness of other incentives if the measures are not wellaligned. Moreover, the example highlights the increase in complexity for taxpayers if they are confronted with a multitude of tax incentives. Similar effects may occur when preferential tax rates and investment allowances are provided simultaneously as the value of an allowance increases in the marginal tax rate. Preferential tax rates could thus, for example, impede incentives to invest in $\mathrm{R} \& \mathrm{D}$ activities.

\subsection{Sensitivity Checks}

Besides the size of a company, other characteristics may impact the way companies are affected by SME tax incentives. The following sensitivity checks therefore examine the effects of changes in profitability, financial leverage, employment and the amount of machinery used by the model companies. The results not only show which kinds of enterprises benefit the most but also provide valuable insight into the mechanics of the incentives.

The results of the sensitivity check on profitability are displayed in Table 5. The relative size of the reliefs (the share of the overall tax burden that is avoided due to SMEspecific provisions) is compared for the base case (micro company) as well as a high-profit and a low-profit scenario. For the high-profit case, the profitability of the model company is raised by $30 \%$ with everything else equal (assets, liabilities, number of employees). Accordingly, profitability drops by $30 \%$ in the low-profit scenario. The case of a firm with negative pre-tax profitability ratios is not considered. It is obvious, though, that loss-making 
firms would only pay non-profit taxes and could not benefit from the implemented tax incentives unless refunds are granted on input-based measures (which is usually not the case).

First of all, the relative size of the reliefs mostly decreases slightly as profitability is raised. This pattern occurs because the size of most reliefs is not affected by a $30 \%$-increase in profitability ${ }^{33}$ while the overall tax liability grows in taxable income. Hence, the relief makes up a smaller share of the overall tax burden for more profitable businesses. Especially big differences between the three scenarios occur in France where the additional income induced by the increase in profitability is not subject to preferential tax rates whereas the income in the low-profit scenario is fully eligible. Consequently, the average corporate income tax rate is significantly lower for the low-profit than for the high-profit firm. With regard to input-based incentives, it needs to be highlighted that the absolute size of the relief only stays the same if marginal tax rates are strictly proportional in the considered interval of profitability. If rates are progressive - usually for non-corporate entities - the advantageousness of allowances and depreciation schemes increases in profitability. With progressive tax rates in place, such incentives would thus provide the smallest reliefs to the neediest businesses with the lowest profits (at least in absolute terms).

The example of France also discloses the redundancy of eligibility criteria explicitly relating to size. If companies beyond a certain size ought not to benefit from an incentive, it is usually enough to set the amount of eligible income, assets or expenses (depending on the type of incentive) sufficiently low. Even if large enterprises are eligible, the relief will then make up such a small share of their overall tax liability that it is negligible for them. They benefit much less than small entities while the incentive to remain small in order not to exceed a certain size threshold is eliminated. Additionally, the administrative effort for taxpayers as well as tax administrations is reduced as firm size does not need to be documented. Moreover, the amount of lost tax revenues should be limited given the small number of large enterprises (and even medium-sized ones). ${ }^{34} \mathrm{~A}$ reverse trend, i.e., a regime being increasingly beneficial as profitability is raised, can be found in Lithuania. Lithuanian micro companies are subject to preferential tax rates which apply up to an income threshold so high that even in the high-profit scenario the model company's income is fully eligible. As

\footnotetext{
${ }^{33}$ The increase in profitability is induced by an increase in sales. Hence, the calculation basis (acquisition cost of fixed assets, amount of equity, number of employees) of input-based incentives stays the same. As CIT rates are mostly proportional, this results in constant absolute reliefs. The relief provided by preferential tax rates also remains unchanged as long as the amount of preferentially treated income remains constant. The income of the micro model company mostly exceeds the eligible amount of income substantially so that the size of the relief is unaffected for these regimes as well.

${ }^{34}$ The percentage of large enterprises in the population of European businesses is $0.2 \%$. See Section 4.1.1.
} 
the share of profit taxes relative to non-profit taxes increases in income, the relative size of the relief also grows. ${ }^{35}$

Table 6 shows the results of the sensitivity check on the equity ratio. A direct impact of the amount of equity on the size of the relief can only be noticed in Belgium and Portugal. In these two countries, companies are allowed to deduct a notional interest on equity. Naturally, the interest deduction increases as more equity is obtained and the incentive regimes become more beneficial. Nevertheless, the average relief of all incentives considered decreases as the equity ratio is raised. This trend is not caused by changes in the actual size of the reliefs (measured in total $€$ ) but by changes in the income against which the reliefs are measured. As more equity is used, the amount of debt decreases so that interest payments and taxable income become smaller. The change in the equity ratio thus triggers a change in the profitability and results in the same effects already observed in the sensitivity check on profitability. ${ }^{36}$ The trend of higher average reliefs for companies that are more levered therefore does not indicate the incentives to be discriminatory against equity financing but rather reflects the debt bias of the overall tax system. ${ }^{37}$

Tables 7 and 8 display further sensitivity checks on the amounts of machinery and employment used by the model company. The schemes of accelerated depreciation in Germany and Lithuania expectedly yield larger reliefs if more machinery is used. Apart from that, the results reinforce the above findings: As machinery and employment are raised, the related expenses, i.e., depreciation and personnel costs, increase and lower the income of the enterprise. In most countries, the absolute size of the relief remains unaffected so that the share of the overall tax liability that is avoided due to SME tax incentives increases. The reverse effect occurs when the amounts of machinery and employment decrease. The mechanism is the same as for the sensitivity check for profitability. ${ }^{38}$

\footnotetext{
${ }^{35}$ In Lithuania, the change in profitability also affects the taxation of the hidden reserves at the end of the sample period. As a consequence, opposing effects occur as profitability is changed. This also explains the increase of the overall relief in the high-profit as well as the low-profit scenario.

${ }^{36}$ The changes in Lithuania deviate from the rest of the sample, i.e., the relative size of the relief increases in the equity ratio. This is due to the high amount of income being eligible to the preferential CIT rates.

${ }^{37}$ For a comprehensive discussion of the debt bias featured in most tax systems, see Section 4.2.2.

${ }^{38}$ Lithuania displays different patterns due to the abovementioned properties of the respective SME incentives.
} 
Table 5: Effect of SME tax incentives by profitability (European Tax Analyzer)

\begin{tabular}{|c|c|c|c|c|c|c|c|c|c|c|c|c|c|c|}
\hline & \multicolumn{5}{|c|}{ Profitability $\mathbf{- 3 0 \%}$} & \multicolumn{4}{|c|}{ Base case } & \multicolumn{5}{|c|}{ Profitability $+\mathbf{3 0 \%}$} \\
\hline & $\begin{array}{c}\text { Tax } \\
\text { base }\end{array}$ & $\begin{array}{c}\text { Tax } \\
\text { credit }\end{array}$ & $\begin{array}{l}\text { Tax } \\
\text { rate }\end{array}$ & Total & $\begin{array}{c}\Delta \text { base } \\
\text { case } \\
\text { (\% points) }\end{array}$ & $\begin{array}{c}\text { Tax } \\
\text { base }\end{array}$ & $\begin{array}{c}\text { Tax } \\
\text { credit }\end{array}$ & $\begin{array}{l}\text { Tax } \\
\text { rate }\end{array}$ & Total & $\begin{array}{r}\text { Tax } \\
\text { base }\end{array}$ & $\begin{array}{c}\text { Tax } \\
\text { credit }\end{array}$ & $\begin{array}{l}\text { Tax } \\
\text { rate }\end{array}$ & Total & $\begin{array}{c}\Delta \text { base } \\
\text { case } \\
\text { (\% points) }\end{array}$ \\
\hline BEL & $-2.17 \%$ & $0.00 \%$ & $-11.56 \%$ & $-13.60 \%$ & 1.45 & $-2.03 \%$ & $0.00 \%$ & $-10.10 \%$ & $-12.15 \%$ & $-1.95 \%$ & $0.00 \%$ & $-8.65 \%$ & $-10.61 \%$ & -1.54 \\
\hline FRA & $0.00 \%$ & $-0.68 \%$ & $-34.48 \%$ & $-35.16 \%$ & 8.85 & $0.00 \%$ & $-0.51 \%$ & $-25.81 \%$ & $-26.31 \%$ & $0.00 \%$ & $-0.40 \%$ & $-20.48 \%$ & $-20.89 \%$ & -5.43 \\
\hline GER & $-0.57 \%$ & $0.00 \%$ & $0.00 \%$ & $-0.57 \%$ & 0.18 & $-0.40 \%$ & $0.00 \%$ & $0.00 \%$ & $-0.40 \%$ & $-0.32 \%$ & $0.00 \%$ & $0.00 \%$ & $-0.32 \%$ & -0.08 \\
\hline HUN & $0.00 \%$ & $0.00 \%$ & $-42.33 \%$ & $-42.33 \%$ & 4.16 & $0.00 \%$ & $0.00 \%$ & $-38.17 \%$ & $-38.17 \%$ & $0.00 \%$ & $-0.47 \%$ & $-34.89 \%$ & $-35.69 \%$ & -2.48 \\
\hline LIT & $-3.04 \%$ & $0.00 \%$ & $-49.43 \%$ & $-52.24 \%$ & 16.81 & $-1.95 \%$ & $0.00 \%$ & $-53.05 \%$ & $-35.42 \%$ & $-1.65 \%$ & $0.00 \%$ & $-55.40 \%$ & $-39.69 \%$ & 4.27 \\
\hline MAL & $0.00 \%$ & $-13.49 \%$ & $0.00 \%$ & $-13.49 \%$ & 3.45 & $0.00 \%$ & $-10.04 \%$ & $0.00 \%$ & $-10.04 \%$ & $0.00 \%$ & $-8.02 \%$ & $0.00 \%$ & $-8.02 \%$ & -2.03 \\
\hline POL & $-0.26 \%$ & $0.00 \%$ & $0.00 \%$ & $-0.26 \%$ & 0.06 & $-0.20 \%$ & $0.00 \%$ & $-0.20 \%$ & $-0.20 \%$ & $-0.16 \%$ & $0.00 \%$ & $0.00 \%$ & $-0.16 \%$ & -0.04 \\
\hline POR & $-1.17 \%$ & $0.00 \%$ & $-3.98 \%$ & $-5.15 \%$ & 1.28 & $-0.88 \%$ & $0.00 \%$ & $-2.99 \%$ & $-3.87 \%$ & $-0.70 \%$ & $0.00 \%$ & $-2.40 \%$ & $-3.10 \%$ & -0.77 \\
\hline ESP & $-0.44 \%$ & $-8.13 \%$ & $-38.96 \%$ & $-47.50 \%$ & 1.94 & $-0.38 \%$ & $-6.10 \%$ & $-39.15 \%$ & $-45.56 \%$ & $-0.30 \%$ & $-4.88 \%$ & $-39.27 \%$ & $-44.40 \%$ & -1.17 \\
\hline Mean & $-0,85 \%$ & $-2,48 \%$ & $-20,08 \%$ & $-23,37 \%$ & 4,24 & $-0,65 \%$ & $-1,85 \%$ & $-18,83 \%$ & $-19,13 \%$ & $-0,56 \%$ & $-1,53 \%$ & $-17,90 \%$ & $-18,10 \%$ & $-1,03$ \\
\hline
\end{tabular}

Table 6: Effect of SME tax incentives by equity ratio (European Tax Analyzer)

\begin{tabular}{|c|c|c|c|c|c|c|c|c|c|c|c|c|c|c|}
\hline & \multicolumn{5}{|c|}{ Equity $-\mathbf{3 0 \%}$} & \multicolumn{4}{|c|}{ Base case } & \multicolumn{5}{|c|}{ Equity $+30 \%$} \\
\hline & $\begin{array}{c}\text { Tax } \\
\text { base }\end{array}$ & $\begin{array}{c}\text { Tax } \\
\text { credit }\end{array}$ & $\begin{array}{l}\text { Tax } \\
\text { rate }\end{array}$ & Total & $\begin{array}{c}\Delta \text { base } \\
\text { case } \\
\text { (\% points) }\end{array}$ & $\begin{array}{c}\text { Tax } \\
\text { base }\end{array}$ & $\begin{array}{c}\text { Tax } \\
\text { credit }\end{array}$ & $\begin{array}{l}\text { Tax } \\
\text { rate }\end{array}$ & Total & $\begin{array}{c}\text { Tax } \\
\text { base }\end{array}$ & $\begin{array}{c}\text { Tax } \\
\text { credit }\end{array}$ & $\begin{array}{l}\text { Tax } \\
\text { rate }\end{array}$ & Total & $\begin{array}{c}\Delta \text { base } \\
\text { case } \\
\text { (\% points) }\end{array}$ \\
\hline BEL & $-1.10 \%$ & $0.00 \%$ & $-10.23 \%$ & $-11.38 \%$ & -0.77 & $-2.03 \%$ & $0.00 \%$ & $-10.10 \%$ & $-12.15 \%$ & $-2.88 \%$ & $0.00 \%$ & $-9.94 \%$ & $-12.81 \%$ & 0.66 \\
\hline FRA & $0.00 \%$ & $-0.54 \%$ & $-27.63 \%$ & $-28.17 \%$ & 1.85 & $0.00 \%$ & $-0.51 \%$ & $-25.81 \%$ & $-26.31 \%$ & $0.00 \%$ & $-0.47 \%$ & $-24.21 \%$ & $-24.69 \%$ & -1.62 \\
\hline GER & $-0.42 \%$ & $0.00 \%$ & $0.00 \%$ & $-0.42 \%$ & 0.03 & $-0.40 \%$ & $0.00 \%$ & $0.00 \%$ & $-0.40 \%$ & $-0.37 \%$ & $0.00 \%$ & $0.00 \%$ & $-0.37 \%$ & -0.02 \\
\hline HUN & $0.00 \%$ & $0.00 \%$ & $-39.18 \%$ & $-39.18 \%$ & 1.01 & $0.00 \%$ & $0.00 \%$ & $-38.17 \%$ & $-38.17 \%$ & $0.00 \%$ & $0.00 \%$ & $-36.72 \%$ & $-36.85 \%$ & -1.33 \\
\hline LIT & $-2.05 \%$ & $0.00 \%$ & $-52.28 \%$ & $-34.03 \%$ & -1.39 & $-1.95 \%$ & $0.00 \%$ & $-53.05 \%$ & $-35.42 \%$ & $-1.87 \%$ & $0.00 \%$ & $-53.73 \%$ & $-36.67 \%$ & 1.25 \\
\hline MAL & $0.00 \%$ & $-10.75 \%$ & $0.00 \%$ & $-10.75 \%$ & 0.71 & $0.00 \%$ & $-10.04 \%$ & $0.00 \%$ & $-10.04 \%$ & $0.00 \%$ & $-9.44 \%$ & $0.00 \%$ & $-9.44 \%$ & -0.60 \\
\hline POL & $-0.21 \%$ & $0.00 \%$ & $0.00 \%$ & $-0.21 \%$ & 0.01 & $-0.20 \%$ & $0.00 \%$ & $-0.20 \%$ & $-0.20 \%$ & $-0.18 \%$ & $0.00 \%$ & $0.00 \%$ & $-0.18 \%$ & -0.01 \\
\hline POR & $-0.14 \%$ & $0.00 \%$ & $-3.20 \%$ & $-3.34 \%$ & -0.53 & $-0.88 \%$ & $0.00 \%$ & $-2.99 \%$ & $-3.87 \%$ & $-1.52 \%$ & $0.00 \%$ & $-2.82 \%$ & $-4.34 \%$ & 0.46 \\
\hline ESP & $-0.40 \%$ & $-6.51 \%$ & $-39.11 \%$ & $-45.96 \%$ & 0.39 & $-0.38 \%$ & $-6.10 \%$ & $-39.15 \%$ & $-45.56 \%$ & $-0.35 \%$ & $-5.73 \%$ & $-39.18 \%$ & $-45.21 \%$ & -0.35 \\
\hline Mean & $-0,46 \%$ & $-2,47 \%$ & $-19,11 \%$ & $-19,13 \%$ & 0,03 & $-0,54 \%$ & $-2,31 \%$ & $-19,08 \%$ & $-19,10 \%$ & $-0,61 \%$ & $-2,17 \%$ & $-18,92 \%$ & $-19,01 \%$ & $-0,09$ \\
\hline
\end{tabular}


Table 7: Effect of SME tax incentives by amount of machinery (European Tax Analyzer)

\begin{tabular}{|c|c|c|c|c|c|c|c|c|c|c|c|c|c|c|}
\hline & \multicolumn{5}{|c|}{ Machinery -15\% } & \multicolumn{4}{|c|}{ Base case } & \multicolumn{5}{|c|}{ Machinery $+\mathbf{1 5 \%}$} \\
\hline & $\begin{array}{c}\text { Tax } \\
\text { base }\end{array}$ & $\begin{array}{c}\text { Tax } \\
\text { credit }\end{array}$ & $\begin{array}{l}\text { Tax } \\
\text { rate }\end{array}$ & Total & $\begin{array}{c}\Delta \text { base } \\
\text { case } \\
\text { (\% points) }\end{array}$ & $\begin{array}{c}\text { Tax } \\
\text { base }\end{array}$ & $\begin{array}{c}\text { Tax } \\
\text { credit }\end{array}$ & $\begin{array}{l}\text { Tax } \\
\text { rate }\end{array}$ & Total & $\begin{array}{c}\text { Tax } \\
\text { base }\end{array}$ & $\begin{array}{c}\text { Tax } \\
\text { credit }\end{array}$ & $\begin{array}{l}\text { Tax } \\
\text { rate }\end{array}$ & Total & $\begin{array}{c}\Delta \text { base } \\
\text { case } \\
\text { (\% points) }\end{array}$ \\
\hline BEL & $-1.76 \%$ & $0.00 \%$ & $-9.56 \%$ & $-11.35 \%$ & -0.80 & $-2.03 \%$ & $0.00 \%$ & $-10.10 \%$ & $-12.15 \%$ & $-2.34 \%$ & $0.00 \%$ & $-10.56 \%$ & $-12.78 \%$ & 0.63 \\
\hline FRA & $0.00 \%$ & $-0.46 \%$ & $-23.33 \%$ & $-23.79 \%$ & -2.52 & $0.00 \%$ & $-0.51 \%$ & $-25.81 \%$ & $-26.31 \%$ & $0.00 \%$ & $-0.56 \%$ & $-28.66 \%$ & $-29.22 \%$ & 2.91 \\
\hline GER & $-0.31 \%$ & $0.00 \%$ & $0.00 \%$ & $-0.31 \%$ & -0.09 & $-0.40 \%$ & $0.00 \%$ & $0.00 \%$ & $-0.40 \%$ & $-0.51 \%$ & $0.00 \%$ & $0.00 \%$ & $-0.51 \%$ & 0.11 \\
\hline HUN & $0.00 \%$ & $-1.05 \%$ & $-36.27 \%$ & $-37.61 \%$ & -0.57 & $0.00 \%$ & $0.00 \%$ & $-38.17 \%$ & $-38.17 \%$ & $0.00 \%$ & $0.00 \%$ & $-39.89 \%$ & $-39.89 \%$ & 1.71 \\
\hline LIT & $-1.79 \%$ & $0.00 \%$ & $-55.82 \%$ & $-57.36 \%$ & 21.94 & $-1.95 \%$ & $0.00 \%$ & $-53.05 \%$ & $-35.42 \%$ & $-2.67 \%$ & $0.00 \%$ & $-49.94 \%$ & $-30.05 \%$ & -5.38 \\
\hline MAL & $0.00 \%$ & $-9.03 \%$ & $0.00 \%$ & $-9.03 \%$ & -1.01 & $0.00 \%$ & $-10.04 \%$ & $0.00 \%$ & $-10.04 \%$ & $0.00 \%$ & $-11.25 \%$ & $0.00 \%$ & $-11.25 \%$ & 1.21 \\
\hline POL & $-0.15 \%$ & $0.00 \%$ & $0.00 \%$ & $-0.15 \%$ & -0.04 & $-0.20 \%$ & $0.00 \%$ & $-0.20 \%$ & $-0.20 \%$ & $-0.25 \%$ & $0.00 \%$ & $0.00 \%$ & $-0.25 \%$ & 0.05 \\
\hline POR & $-0.55 \%$ & $0.00 \%$ & $-2.70 \%$ & $-3.25 \%$ & -0.62 & $-0.88 \%$ & $0.00 \%$ & $-2.99 \%$ & $-3.87 \%$ & $-1.26 \%$ & $0.00 \%$ & $-3.34 \%$ & $-4.60 \%$ & 0.72 \\
\hline ESP & $-0.29 \%$ & $-5.49 \%$ & $-39.30 \%$ & $-45.04 \%$ & -0.52 & $-0.38 \%$ & $-6.10 \%$ & $-39.15 \%$ & $-45.56 \%$ & $-0.41 \%$ & $-6.81 \%$ & $-38.96 \%$ & $-46.17 \%$ & 0.60 \\
\hline Mean & $-0,44 \%$ & $-2,22 \%$ & $-19,16 \%$ & $-21,82 \%$ & 2,73 & $-0,54 \%$ & $-2,31 \%$ & $-19,08 \%$ & $-19,10 \%$ & $-0,73 \%$ & $-2,58 \%$ & $-18,88 \%$ & $-18,96 \%$ & $-0,14$ \\
\hline
\end{tabular}

Table 8: Effect of SME tax incentives by employment intensity (European Tax Analyzer)

\begin{tabular}{|c|c|c|c|c|c|c|c|c|c|c|c|c|c|c|}
\hline & \multicolumn{5}{|c|}{ Employment -30\% } & \multicolumn{4}{|c|}{ Base case } & \multicolumn{5}{|c|}{ Employment $+\mathbf{3 0} \%$} \\
\hline & $\begin{array}{c}\text { Tax } \\
\text { base }\end{array}$ & $\begin{array}{c}\text { Tax } \\
\text { credit }\end{array}$ & $\begin{array}{l}\text { Tax } \\
\text { rate }\end{array}$ & Total & $\begin{array}{c}\Delta \text { base } \\
\text { case } \\
\text { (\% points) }\end{array}$ & $\begin{array}{c}\text { Tax } \\
\text { base }\end{array}$ & $\begin{array}{c}\text { Tax } \\
\text { credit }\end{array}$ & $\begin{array}{l}\text { Tax } \\
\text { rate }\end{array}$ & Total & $\begin{array}{c}\text { Tax } \\
\text { base }\end{array}$ & $\begin{array}{c}\text { Tax } \\
\text { credit }\end{array}$ & $\begin{array}{l}\text { Tax } \\
\text { rate }\end{array}$ & Total & $\begin{array}{c}\Delta \text { base } \\
\text { case } \\
\text { (\% points) }\end{array}$ \\
\hline BEL & $-1.98 \%$ & $0.00 \%$ & $-9.56 \%$ & $-11.56 \%$ & -0.59 & $-2.03 \%$ & $0.00 \%$ & $-10.10 \%$ & $-12.15 \%$ & $-2.09 \%$ & $0.00 \%$ & $-10.70 \%$ & $-12.81 \%$ & 0.66 \\
\hline FRA & $0.00 \%$ & $-0.46 \%$ & $-22.74 \%$ & $-23.21 \%$ & -3.11 & $0.00 \%$ & $-0.51 \%$ & $-25.81 \%$ & $-26.31 \%$ & $0.00 \%$ & $-0.56 \%$ & $-29.48 \%$ & $-30.04 \%$ & 3.72 \\
\hline GER & $-0.38 \%$ & $0.00 \%$ & $0.00 \%$ & $-0.38 \%$ & -0.02 & $-0.40 \%$ & $0.00 \%$ & $0.00 \%$ & $-0.40 \%$ & $-1.02 \%$ & $0.00 \%$ & $0.00 \%$ & $-1.02 \%$ & 0.62 \\
\hline HUN & $0.00 \%$ & $0.00 \%$ & $-36.98 \%$ & $-36.98 \%$ & -1.19 & $0.00 \%$ & $0.00 \%$ & $-38.17 \%$ & $-38.17 \%$ & $0.00 \%$ & $0.00 \%$ & $-39.36 \%$ & $-39.36 \%$ & 1.19 \\
\hline LIT & $-1.87 \%$ & $0.00 \%$ & $-53.66 \%$ & $-35.55 \%$ & 0.12 & $-1.95 \%$ & $0.00 \%$ & $-53.05 \%$ & $-35.42 \%$ & $-2.04 \%$ & $0.00 \%$ & $-52.37 \%$ & $-54.12 \%$ & 18.69 \\
\hline MAL & $0.00 \%$ & $-9.50 \%$ & $0.00 \%$ & $-9.50 \%$ & -0.54 & $0.00 \%$ & $-10.04 \%$ & $0.00 \%$ & $-10.04 \%$ & $0.00 \%$ & $-10.66 \%$ & $0.00 \%$ & $-10.66 \%$ & 0.62 \\
\hline POL & $-0.19 \%$ & $0.00 \%$ & $0.00 \%$ & $-0.19 \%$ & -0.01 & $-0.20 \%$ & $0.00 \%$ & $-0.20 \%$ & $-0.20 \%$ & $-0.21 \%$ & $0.00 \%$ & $0.00 \%$ & $-0.21 \%$ & 0.01 \\
\hline POR & $-0.83 \%$ & $0.00 \%$ & $-2.84 \%$ & $-3.67 \%$ & -0.20 & $-0.88 \%$ & $0.00 \%$ & $-2.99 \%$ & $-3.87 \%$ & $-0.93 \%$ & $0.00 \%$ & $-3.17 \%$ & $-4.10 \%$ & 0.23 \\
\hline ESP & $-0.36 \%$ & $-5.77 \%$ & $-39.19 \%$ & $-45.26 \%$ & -0.30 & $-0.38 \%$ & $-6.10 \%$ & $-39.15 \%$ & $-45.56 \%$ & $-0.40 \%$ & $-6.46 \%$ & $-39.11 \%$ & $-45.90 \%$ & 0.34 \\
\hline Mean & $-0,52 \%$ & $-2,18 \%$ & $-18,95 \%$ & $-18,79 \%$ & $-0,31$ & $-0,54 \%$ & $-2,31 \%$ & $-19,08 \%$ & $-19,10 \%$ & $-0,66 \%$ & $-2,45 \%$ & $-19,14 \%$ & $-22,20 \%$ & 3,10 \\
\hline
\end{tabular}




\section{Policy Rationale for SME Tax Incentives}

The analysis in Sections 2 and 3 illustrates the common use of tax incentives for SMEs in general and for micro enterprises in particular in the European Union. The multitude of available incentives naturally raises the question of the rationale behind these regimes that come along with significant costs. Besides substantial losses in tax revenues, the partitioning of taxpayers compromises the neutrality and the equity of the tax system and enhanced complexity raises compliance as well as collection costs. Well-grounded SME tax incentives must thus provide substantial benefits in order to yield a net gain and increase the overall social welfare. ${ }^{39}$ And while it seems that supporting small businesses has become a generally accepted mantra among policy-makers and lobbyists, ${ }^{40}$ existing evidence on the benefits of SME tax incentives is mixed - at best. An adequate evaluation of the effectiveness and the efficiency of SME tax incentives thus requires a thorough examination of the arguments brought forward.

\subsection{Non-Tax Arguments}

\subsubsection{Size of the SME Sector}

The mere size of the SME sector and its importance for the economy as a whole are frequently cited in public discussions as a reason for special support schemes. SMEs are commonly labeled the "backbone" 41 or the "engine" 42 of the economy. A look at the statistics confirms this role. SMEs account for $99.8 \%$ of all enterprises in the non-financial business sector in the European Union and for $67 \%$ of employment and $58 \%$ of the value added (see Figure $6^{43}$ ). Among the three subcategories, micro enterprises make up the largest share as $92.7 \%$ of all businesses fall in this category. They alone provide almost $30 \%$ of all jobs in the EU. ${ }^{44}$ In the United States, where $99.7 \%$ of all businesses have less than 500 employees in 2012 (i.e., possess the status of an SME according to U.S. standards), the numbers are similar. SMEs also provide $48.4 \%$ of total employment in the U.S and account for about $50 \%$ of the

\footnotetext{
${ }^{39}$ See Zee/Stotsky/Ley (2002) pp. 1501 f.; Klemm (2010) p. 323; Arginelli (2015) pp. 17 f.

${ }^{40}$ See de Rugy (2005) p. 5.

${ }^{41}$ See White House (2010): https://www.whitehouse.gov/blog/2010/08/17/small-businesses-are-backbone-oureconomy-and-cornerstones-our-communities (retrieved on August 15, 2016); The Guardian (2014): http://www. theguardian.com/small-business-network/2014/dec/06/small-businesses-backbone-communities-john-longworth (retrieved on August 15, 2016).

${ }^{42}$ See $\quad$ Bundesministerium für Wirtschaft und http://www.midasgruppe.de/uploads/media/German_Mittelstand_Motor_der_deutschen_Wirtschaft_BMWI.pdf (retrieved on October 25, 2016).

${ }^{43}$ Figure 6 is based on data provided by the European Commission. See European Commission (2015a) pp. $3 \mathrm{ff}$.

${ }^{44}$ See European Commission (2015a) p. 7.
} 
GDP. ${ }^{45}$ Altogether, SMEs indeed make up a large part or even the majority of employment and economic output in most countries. Their importance for the economy and the job market is indisputable.

Figure 6: Contribution of SMEs to the economy in the EU (2014)

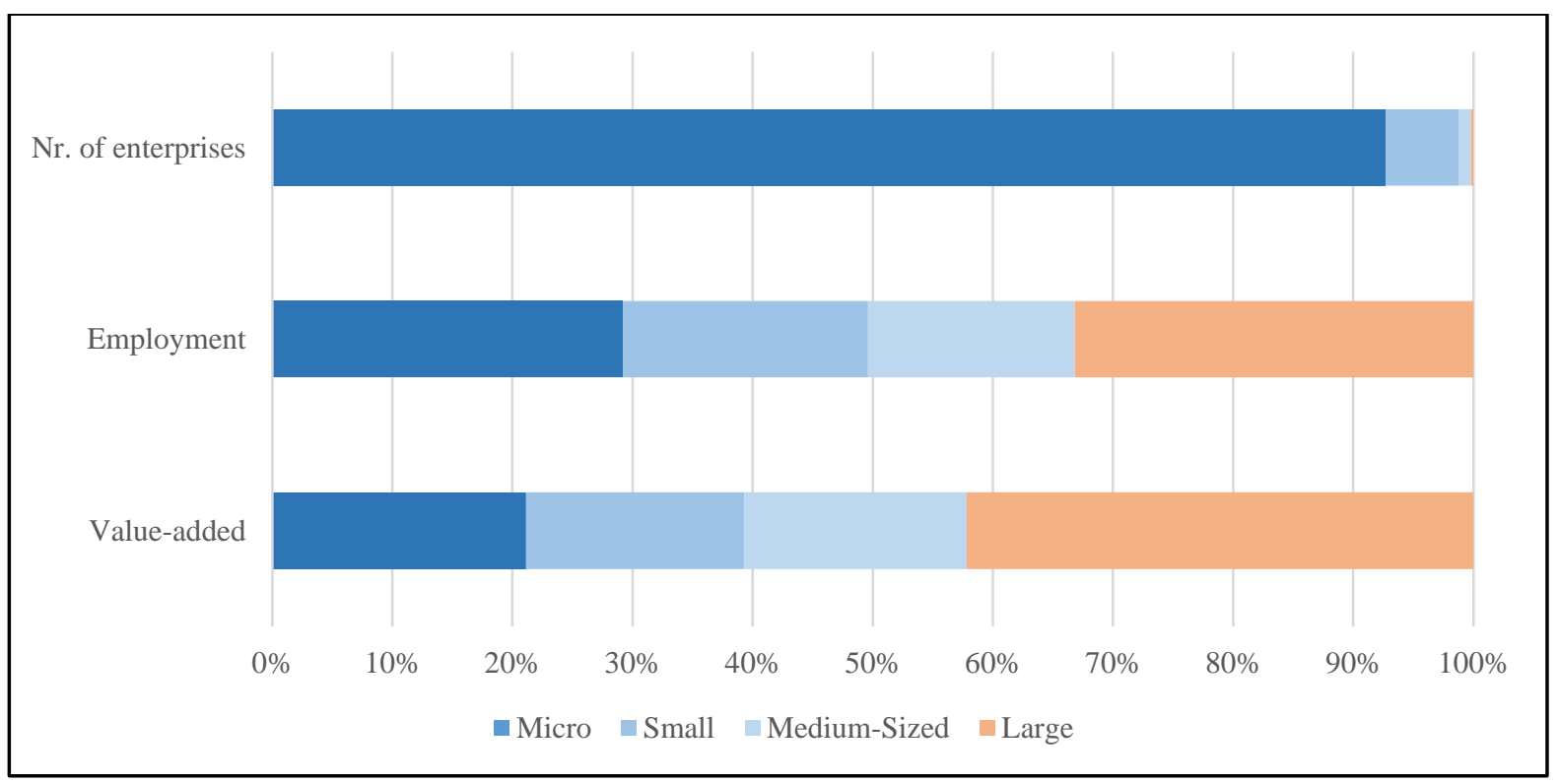

The question at hand, however, is not whether SMEs produce more output and employment then large businesses in absolute terms but rather if incremental investments in promoted SMEs create more output and jobs than comparable investments in large companies that would have been undertaken in the absence of SME tax incentives. ${ }^{46}$ In a market economy, investors take their decisions with the intention of profit maximization. They invest in the undertakings promising the highest returns, which are usually the most efficient and productive ones. Hence, there should not be a need for reallocating capital - unless market failure occurs. In general, the open market should lead to an efficient allocation optimizing social welfare whereas government intervention mostly causes economically suboptimal results. ${ }^{47}$ The mere size of the SME sector and its absolute contribution to the economy therefore do not constitute valid arguments for the provision of special tax incentives based on firm size. However, the size of the SME sector may hint at the amount of political influence of small businesses and their lobbyists, thus providing an explanation rather than a justification for politicians' proneness to implement and preserve such measures. ${ }^{48}$

\footnotetext{
${ }^{45}$ See Caruso (2015) p. 7.

${ }^{46}$ See Guenther (2004) p. 22; OECD (2009a) pp. 84 ff.

${ }^{47}$ See Winston (2006) pp. $73 \mathrm{ff}$.

${ }^{48}$ See Crawford/Freedman (2010) p. 1086; OECD (2010a) pp. 57 ff.; Qureshi (2013) pp. 19 ff.
} 


\subsubsection{Job Creation}

While the mere size of the SME sector does not suffice as a reason for special tax reliefs or other regulatory advantages, there may be other arguments. SMEs' role for employment is probably the most prominent one in public discussions. Employment, of course, is a major policy goal in the European Union. ${ }^{49}$ It is desirable from a social point of view and it plays a key role for the national budget. ${ }^{50}$ More employment means less spending for social benefits and increased tax revenues and social security contributions. SME tax incentives would thus make sense, if they led to additional SME activity that comes along with additional employment. Obviously, this rationale assumes SMEs to be more dynamic, to grow faster and to generate more jobs than large enterprises. A dollar invested in the SME sector must have more desirable employment implications than a dollar invested in large businesses, which should show in higher rates of job creation. ${ }^{51}$

In public perception, the leading role of SMEs in job creation seems to be undoubted. $^{52}$ The academic discussion whether small businesses contribute more to job creation than large enterprises has been fierce, though. The debate was kicked-off by French economist Robert Gibrat. His rule of proportionate growth, also called Gibrat's Law, claims firm growth to be independent of absolute firm size. ${ }^{53}$ Hence, SMEs should have the same expected growth rates as large entities and create new jobs at the same rates. In the 1950s and 60s, however, empirical evidence casted major doubts on Gibrat's Law and the assumption of proportionate growth became subject to some qualifications. Most notably, Hart and Prais (1956) contended that it only holds for surviving firms while Simon and Bonini (1958) observed Gibrat's Law to apply only if firms reach a so-called minimum efficient scale level of output. Businesses, in other words, need to reach a minimum size in order to generate sufficient economies of scale. Enterprises not reaching the minimum exit the market, which would explain the necessity for SMEs to grow faster. ${ }^{54}$

Due to data limitations, empirical evidence was scarce until the 1980s when a couple of studies by Birch reignited the discussion on the dynamics of firm and employment growth. ${ }^{55}$ Using data from the U.S. manufacturing industry, Birch (1981) finds establishments

\footnotetext{
${ }^{49}$ See European Commission (2010a) pp. 3 ff.; European Commission (2010b) pp. 3 ff.

${ }^{50}$ See European Commission (2014) pp. $11 \mathrm{ff}$.

${ }^{51}$ See Bolnick (2004) pp. 4-10 f.

${ }^{52}$ See Davis/Haltiwanger/Schuh (1996a) p. 298; de Rugy (2005) p. 5.

${ }^{53}$ See Simon/Bonini (1958) pp. $608 \mathrm{f}$.

${ }^{54}$ See Hart/Prais (1956) pp. 161 ff.; Simon/Bonini (1958) pp. 608 ff.

${ }^{55}$ See Birch (1981) pp. 3 ff.; Birch (1987) pp. 7 ff.
} 
with less than 20 employees to be responsible for about two thirds of all new jobs in the U.S. in the period from 1969 to 1976 . Establishments with more than 100 employees, in contrast, only provided $20 \%$ of newly created employment despite employing $65 \%$ of the total workforce. ${ }^{56}$ For the period from 1981 to 1985 , Birch (1987) reports similar results and barely finds any net job creation among large enterprises. ${ }^{57}$ The findings strongly support the image of the SME sector to be the engine of growth and employment. In fact, the results indicate the small business sector (firms with less than 100 employees according to Birch's definition) to create jobs at a net rate that is at least eight times as high as the large business rate. ${ }^{58}$

Birch's findings shaped the academic view as well as the perception of politicians and the public that small businesses are the major source of employment and growth. ${ }^{59}$ His data and his analysis, however, were questioned by several authors. Numerous studies on the dynamics of firm growth and job creation followed his work. Interestingly, the results obtained are quite diverse. While some studies confirm Birch's findings, others report no or only a weak link between employment growth and absolute firm size. ${ }^{60}$ The diversity of results has also been accompanied by a discussion of several methodological questions that may - at least partly - have driven Birch's results. As his findings would indeed provide a strong argument in favor of an advantageous tax treatment for SMEs, it is essential to gain an understanding of the underlying methodological issues and resolve the question if the SME sector as a whole really create more jobs.

\section{1) Data quality}

In his seminal paper Birch uses longitudinal data on a large sample of U.S. establishments in the period from 1969 to $1976 .{ }^{61}$ The data was collected by Dun and Bradstreet (D\&B), a private-sector firm providing customers with commercial information such as credit records and ratings. ${ }^{62}$ Being designed for other purposes than research on job creation, the dataset by D\&B suffers several shortcomings. First of all, the correctness of the employment numbers is doubtful. The sum of all jobs registered in the $\mathrm{D} \& \mathrm{~B}$ files, for example, exceeds the employment totals given by the

\footnotetext{
${ }^{56}$ See Birch (1981) pp. 7 ff.

${ }^{57}$ See Birch (1987) pp. $12 \mathrm{ff}$.

${ }^{58}$ See Birch (1981) pp. 7 ff.; Birch (1987) pp. 12 ff.

${ }^{59}$ See Davis/Haltiwanger/Schuh (1996a) pp. $297 \mathrm{f}$.

${ }^{60}$ See Table A1 in Annex 2 for an overview of empirical studies on the relation of firm size and job creation.

${ }^{61}$ The sample used by Birch contains about $80 \%$ of all recognized establishments during the sample period. See Birch (1981) p. 4.

${ }^{62}$ See Dun \& Bradsheet: http://www.dnb.com/company.html (retrieved on April 1, 2016).
} 
U.S. Bureau of Labor Statistics by 8 million jobs in $1986 .{ }^{63}$ Research has shown the data to be particularly error-prone for small and young businesses. ${ }^{64}$ With regard to Birch's object of investigation, i.e., the role of the small business sector in job creation, this is worrisome. The recording of mergers and acquisitions (M\&A) as well as changes in the organizational form of businesses are further concerns with the D\&B data. These events are often not properly accounted for and numbers on job creation and destruction could be biased in favor of the small business sector. ${ }^{65}$

These shortcomings of Birch's data indeed cast some doubts on the reliability of his results and those of several other studies using similar data. A negative correlation of absolute firm size and employment growth, however, is also confirmed by numerous other studies, albeit at a smaller magnitude. Mostly, these studies employ datasets with better coverage (including micro enterprises) and a more accurate recording of firm births and changes in ownership structures. ${ }^{66}$ The basic finding of small firms growing faster than large enterprises should therefore not solely be attributed to poor data quality. The magnitude of the difference in growth rates as reported by Birch should be considered with caution, though.

\section{2) Manufacturing vs. services}

Most studies finding comparatively high growth rates for the small business sector (including Birch's work) only cover manufacturing enterprises. ${ }^{67}$ Manufacturing, however, may be subject to different growth dynamics than other sectors. Firstly, growth patterns could be impacted by a general decline of the secondary sector relative to the service sector in industrialized countries. Production activities have

\footnotetext{
${ }^{63}$ See Davis/Haltiwanger/Schuh (1996a) p. 307.

${ }^{64}$ The D\&B data does, for example, not include over $90 \%$ of newly founded businesses that appear in alternative sources. See Birley (1984) pp. $66 \mathrm{ff}$.

${ }^{65}$ For many M\&A transactions, firms and establishments are reported to be closed (and the jobs to be lost) by the S\&B data although they were only acquired by new owners. The acquirer, on the other hand, would seem to create lots of jobs even though the increase in employment is attributable to the acquisition. As the target company should usually be smaller than the acquirer, this shortcoming in the data would lead to an underestimation of small businesses' growth rates if the firm level was considered. Birch, however, examines job creation at the establishment level. Hence, the data shows the establishment to close down and reopen. The direction of the bias thus depends on the post-acquisition development of the respective establishment and the exact recording of the transaction. See Davis/Haltiwanger/Schuh (1996a) p. 307; Haltiwanger/Jarmin/Miranda (2013) p. $348 \mathrm{f}$.

${ }^{66} \mathrm{See}$ Dunne/Roberts/Samuelson (1989) pp. 671 ff.; Mata/Portugal (1994) pp. 227 ff.; Davidsson/Lindmark/Olofsson (1998) pp. 87 ff.; Barnes/Haskel (2002) pp. 1 ff.; Lotti/Santarelli/Vivarelli (2003) pp. 213 ff.; Voulgaris/Papadogonas/Agiomirgianakis (2005) pp. 289 ff.; Lotti (2007) pp. 347 ff.; Headd/Kirchhoff (2009) pp. $531 \mathrm{ff}$.

${ }^{67}$ See Davis/Haltiwanger/Schuh (1996a) pp. 308 f. Table A1 in Annex 2 also gives a comprehensive overview of the existing empirical literature on the subject.
} 
been increasingly outsourced by multinational enterprises to other countries with lower wage costs. As a consequence, the growth rates of large companies may be extraordinarily low when only considering the manufacturing sector. ${ }^{68}$ Secondly, small manufacturers could be particularly hard-pressed to reach a minimum scale of operations as economies of scale are more distinct in manufacturing than in the service sector. ${ }^{69}$

The issue of a manufacturing bias has been addressed by several studies. Audretsch et al. (2004) examine the Dutch hospitality sector while several other works use samples covering most or all sectors of the respective economies. The vast majority of them find a correlation of absolute firm size and growth rates. ${ }^{70}$ The studies, however, generally report the magnitude of the discrepancy between large and small businesses to be much smaller than estimated by Birch. Armington and Odle (1982) as well as Davidsson et al. (1998), for example, only observe a weak negative relation when considering all sectors. ${ }^{71}$ Dunne and Hughes (1994) and Lotti (2007) confirm this and observe the differences to become even smaller (if not negligible) when businesses with less than 20 employees are excluded. ${ }^{72}$ It is, in other words, primarily micro enterprises driving growth rates.

\section{3) Firm-level data vs. establishment-level data}

Most studies on growth dynamics and job creation aim at explaining the connection between firm size and firm growth. Still, Birch (1981) as well as numerous other works measure employment at the establishment or even the plant level. ${ }^{73}$ Basing policy advice on results from establishment-level data is problematic, though. A

\footnotetext{
${ }^{68}$ See Davis/Haltiwanger/Schuh (1996a) pp. 308 f.; Lotti (2007) pp. 349 f.

${ }^{69}$ In the European Union, the average size of businesses (measured in turnover) in the manufacturing sector substantially exceeds the average size in the service sector, which suggests firm size and economies of scale to play a bigger role in manufacturing. On the other hand, economies of scale may also drive results in the opposite direction if the advantage of being large does not even allow small businesses to compete and develop. See European Commission (2004) p. 12; Hurst/Pugsley (2015) pp. 1 ff.

${ }^{70}$ See Kirchhoff/Phillips (1988) pp. 261 ff.; Gallagher/Daly/Thomason (1991) pp. 269 ff.; Amirkhalkhali/ Mukhopadhyay (1993) pp. 223 ff.; Dunne/Hughes (1994) pp. 115 ff.; Harhoff/Stahl/Woywode (1998) pp. 453 ff.; Heshmati (2001) pp. 213 ff.; Lotti (2007) pp. 347 ff.; Headd/Kirchhoff (2009) pp. 531 ff.; Headd (2010) pp. 1 ff.; de Kok/Vroonhof/Verhoeven/Timmermans/Kwaak/Snijders/Westhof (2011) pp. $27 \quad \mathrm{ff}$; Nassar/Almasafir/Al-Mahrouq (2013) pp. 266 ff.; de Wit/de Kok (2014) pp. 283 ff. The only study using a sample of non-manufacturing firms and not observing a clear correlation between firm size and growth rates comes from Audretsch et al. (2004). Their results may be caused by the peculiarities of the hospitality sector that they focus on, though. See Audretsch/ Klomp/Santarelli/Thurik (2004) pp. $301 \mathrm{ff}$.

${ }^{71}$ See Armington/Odle (1982) pp. 14 ff.; Davidsson/Lindmark/Olofsson (1997) pp. 87 ff.

${ }^{72}$ See Dunne/Hughes (1994) pp. 115 ff.; Lotti (2007) pp. 347 ff.

${ }^{73}$ See Table A1 in Annex 2 for an overview of the data used by empirical studies on firm growth and job creation.
} 
small establishment can still be part of a large firm. Hence, small establishments growing faster than large establishments does not necessarily prove small firms to grow faster than large firms. ${ }^{74}$ With regard to justifying SME tax incentives, this is problematic because tax incentives target firms, not establishments. There are even anti-misuse provisions coming along with several of the currently available regimes that ought to prevent small branches of large businesses from gaining admission. ${ }^{75}$ Hence, the question to be posed for the currently available regimes is not whether small establishments (or plants) generate more jobs but whether small firms do so. ${ }^{76}$

In addition, there is a methodological problem related to establishment-level data. Unless sufficient ownership information is provided, such data automatically drives the results towards a negative relation of firm size and job creation because any job creation by a small establishment being part of a large company is mistakenly attributed to the SME sector. As a consequence, SMEs' role in job creation is overestimated while the contribution of large businesses is undervalued. The extent of this bias is demonstrated by Armington and Odle (1982) who report the small business share of net job creation to be cut in half from $78 \%$ to $39 \%$ in Birch's data when correctly accounting for firm size (instead of establishment size). ${ }^{77}$ There are, however, numerous other studies working with firm-level data which also find a robust negative correlation of firm size and firm growth. ${ }^{78}$ Even Odle and Armington (1982) observe small entities to create a disproportionally high number of jobs. The general finding of small businesses growing faster and creating more jobs on average than large entities should thus hold for the firm level as well. Again, the difference in job creation rates found by firm-level studies is smaller than reported by Birch (1981), though.

4) Netting out reality and regression to the mean

\footnotetext{
${ }^{74}$ See Armington/Odle (1982) $\quad$ pp. $14 \quad$ f.; $\quad$ Davis/Haltiwanger/Schuh $\quad(1996 a) \quad$ pp. $\quad 300 \quad$ f.; Haltiwanger/Jarmin/Miranda (2013) p. 349.

${ }^{75}$ A more detailed description of these rules, e.g., in France or Lithuania, is given in the country reports in Annex 1 .

${ }^{76}$ The same applies to other elements of the regulatory environment, e.g., financial reporting duties. See Buschhüter/Striegel (2015) p. 24.

${ }^{77}$ See Armington/Odle (1982) pp. 15 f. On the other hand, establishment-level data may provide advantages with regard to the analysis of gross job creation, especially if M\&A transactions are not accounted for properly. See Barnes/Haskel (2002) p. 5; Haltiwanger/Jarmin/Miranda (2013) p. 348.

${ }^{78}$ See, for example, Evans (1987a) pp. 657 ff.; Evans (1987b) pp. 567 ff.; Gallagher/Daly/Thomason (1991) pp. 269 ff.; Broersma/Gautier (1997) pp. 211 ff.; Voulgaris/Papadogonas/Agiomirgianakis (2005) pp. 289 ff.
} 
Besides the data used by Birch (1981), follow-up studies also criticized his methodological approach. ${ }^{79}$ Birch's basic idea is to divide the population of firms into several size classes and to measure the number of jobs created and destroyed by each size category over the sample period. The net gain in employment ("net job creation") is his measure of interest. Based on this measures, he assesses the relative importance of small and large firms for job creation. ${ }^{80}$

Figure 7 illustrates how this focus on net changes in employment can give a wrong image of small and large businesses' role in job creation. In the example, small businesses only generate $20 \%$ of the new jobs but they account for $100 \%$ of net job creation. Merely considering the latter number would thus imply the impression of small businesses being the sole creators of new jobs. For the overall employment situation, however, it would be more harmful to lose the jobs provided by large enterprises. Hence, it is important to take net as well as gross numbers of job creation into account. ${ }^{81}$

Figure 7: Net and gross job creation (example)

\begin{tabular}{|c|c|c|c|c|c|c|}
\hline & $\begin{array}{l}\text { Firm } 1 \\
\text { (small) }\end{array}$ & $\begin{array}{l}\text { Firm } 2 \\
\text { (large) }\end{array}$ & $\begin{array}{l}\text { Firm } 3 \\
\text { (large) }\end{array}$ & $\begin{array}{l}\text { Small } \\
\text { firms }\end{array}$ & $\begin{array}{l}\text { Large } \\
\text { firms }\end{array}$ & All firms \\
\hline Employment $_{\mathrm{t}=1}$ & 30 & 60 & 60 & 30 & 120 & 150 \\
\hline Employment $_{t=2}$ & 35 & 40 & 80 & 35 & 120 & 155 \\
\hline Net change & 5 & -20 & +20 & +5 & 0 & +5 \\
\hline \multicolumn{7}{|c|}{ Small-firm share of net job creation: $\quad 100 \%(=5 / 5)$} \\
\hline
\end{tabular}

The main methodological criticism of Birch, however, refers to the so-called regression fallacy (also: regression to the mean). This is a statistical pitfall that occurs when businesses are misclassified as either small or large due to transitory, not serially correlated shocks in employment. ${ }^{82} \mathrm{~A}$ (borderline) large company, for example, can experience a temporary one-year decline in employment. If the classification of firms as either small or large is solely based on this year, the company falls in the small businesses category despite generally being a large enterprise. When the company returns to the normal number of employees in the

\footnotetext{
${ }^{79}$ See Davis/Haltiwanger/Schuh (1996a) p. 299 ff.; Davis/Haltiwanger/Schuh (1996b) pp. 62 ff.

${ }^{80}$ See Birch (1981) pp. 7 ff.

${ }^{81}$ See Davis/Haltiwanger/Schuh (1996b) p. 66; Neumark/Wall/Zhang (2011) p. 20.

${ }^{82}$ See Haltiwanger/Jarmin/Miranda (2013) p. 349.
} 
following year, the new jobs are reported to be created by a small firm. Similarly, jobs are recorded as being lost by a large enterprise when a small business experiences a positive transitory shock in the base year before returning to the normal level of employment in the following period. Ultimately, the regression fallacy thus always induces the growth rate of small enterprises to be overestimated while the large business rate is always depressed. ${ }^{83}$

Birch's analysis is especially prone to the regression fallacy because his size classification is solely based on the number of employees in the first sample year. Davis et al. (1996a, b) therefore propose the use of average size measurements that take multiple years into account. ${ }^{84}$ For a similar dataset, they replicate Birch's findings using the base-year method while not observing any systematic relation between firm size and employment growth for their alternative measures. They interpret this as a proof of Birch's findings to be driven by the regression fallacy. ${ }^{85}$ It needs to be pointed out, though, that their alternative measures also lead to misclassifications and introduce new bias. One bias is thus reduced at the cost of a new one. The question of which measure (or rather which bias) is more acceptable ultimately depends on the frequency of transitory shocks.

Either way, the cumulative body of follow-up studies indicates that the general finding of a negative correlation of absolute firm size and employment growth still holds when accounting for the regression bias. Several studies follow the approach of Davis et al. (1996a, b) and still confirm small firms to create more jobs on average. The correlation is less distinct for average size than it is for the base-year classification in these studies, though. ${ }^{86}$ Davidsson et al. (1998), Fariñas and Moreno (2000) and Botazzi et al. (2001) also run explicit tests to determine the impact of the regression fallacy and only find it to play a minor role. ${ }^{87}$

\section{5) Firm size vs. firm age}

\footnotetext{
${ }^{83}$ See Davis/Haltiwanger/Schuh (1996a) p. $305 \mathrm{ff}$.

${ }^{84}$ See Davis/Haltiwanger/Schuh (1996a) pp. $305 \mathrm{f}$.

${ }^{85}$ Average size takes the average number of employees over all observation periods while current size only includes all observations up to the current year. See Davis/Haltiwanger/Schuh (1996a) pp. 305 f.; Davis/Haltiwan-ger/Schuh (1996b) pp. $66 \mathrm{ff}$.

${ }^{86}$ See Broersma/Gautier (1997) pp. 211 ff.; Neumark/Wall/Zhang (2011) p. 16 ff.; Haltiwanger/Jarmin/Miranda (2013) pp. $355 \mathrm{ff}$.

${ }^{87}$ See Davidsson/Lindmark/Olofsson (1998) pp. 87 ff.; Fariñas/Moreno (2000) pp. 249 ff.; Bottazzi/Dosi/Lippi/ Pammolli/Riccaboni (2001) pp. 1161 ff.
} 
In his seminal paper, Birch (1981) claims small enterprises to create more jobs on average than their larger counterparts. As shown above, this finding has been scrutinized in many follow-up analyses. Comparatively little attention, however, has been paid to his second main finding that firm age is also negatively correlated with net job creation. In fact, $80 \%$ of all new jobs in his sample are accounted for by establishments not older than four years ${ }^{88}$ and Birch clearly states that most small businesses are no creators of jobs. It is rather a small group of young, expanding start-ups that outgrow the small business category quickly. ${ }^{89}$

Confirmation comes from Armington and Odle (1982), Kirchhoff and Phillips (1988) and Broersma and Gautier (1997) who find firm births to account for 30\%, $50 \%$ and $100 \%$, respectively, of net job creation in their samples. ${ }^{90}$ Voulgaris et al. (2005) and Lotti (2007) report only the group of firms that are younger than 5 and 10 years, respectively, to have positive rates of net job creation. ${ }^{91}$ Further evidence comes from Dunne et al. (1988) and Headd and Kirchhoff (2009) who do not observe businesses to grow much at all after the start-up phase. ${ }^{92}$ Audretsch and Mahmood (1994) and Tang (2015) also believe most firms to settle in once they have reached the minimum efficient scale. ${ }^{93}$ Regression-based studies featuring firm size and firm age as explanatory variables find both measures to negatively affect expected employment growth. Interestingly, Harhoff et al. (1998) observe the relation to be more pronounced for size while Voulgaris et al. (2005), Davidsson et al. (1998) and Haltiwanger et al. (2013) rather see the newness of businesses driving employment growth. $^{94}$

Summing up, empirical evidence generally confirms Birch's finding of absolute firm size being negatively correlated with rates of job creation and firm growth. The perception of

\footnotetext{
${ }^{88}$ See Birch (1981) p. 8.

${ }^{89}$ See Birch (1981) pp. 8 f.

${ }^{90}$ See Armington/Odle (1982) pp. 15; Kirchhoff/Phillips (1988) pp. 266 ff.; Broersma/Gautier (1997) pp. 216 ff.

${ }^{91}$ See Voulgaris/Papadogonas/Agiomirgianakis (2005) p. 295; Lotti (2007) p. 355.

${ }^{92}$ This empirical evidence is also in line with more recent theoretical models that seek to resolve the contradiction between empirically observed growth patterns and Gibrat's Law by interpreting growth as a learning process in which firms gradually find out about their deficiencies and as a consequence become increasingly efficient. As firms mature, the learning process slows down and so does firm growth. Naturally, firms starting out small have to learn more, i.e., grow faster, in order to be competitive. See Jovanovic (1982) pp. 649 ff.; Dunne/Roberts/Samuelson (1988) p. 509 ff.; Cabral (1995) pp. 161 ff.; Ericson/Pakes (1995) pp. 53 ff.; Head/Kirchoff (2009) pp. $540 \mathrm{f}$.

${ }^{93}$ See Audretsch/Mahmood (1994) pp. 247 ff.; Tang (2015) pp. 659 ff.

${ }^{94}$ See Evans (1987a) pp. 657 ff.; Dunne/Roberts/Samuelson (1989) pp. 671 ff.; Fariñas/Moreno (2000) pp. 249 ff.; Harhoff/Stahl/Woywode (1998) pp. 453 ff.; Voulgaris/Papadogonas/Agiomirgianakis (2005) pp. 289 ff.; Haltiwanger/Jarmin/Miranda (2013) pp. 347 ff.
} 
solely small businesses creating new jobs is wrong, though. The prevalence of this perception is in part due to the results of Birch's studies that are driven by methodological deficiencies and problems relating to data quality. In addition, the ignorance of Birch's second main finding is key in explaining the misconception of small businesses' role in job creation: It is not small firms as a whole growing faster but only the so-called gazelles, the group of highgrowth firms that are usually both small and young. ${ }^{95}$ Recent evidence even suggests firm age to be the main determinant of expected growth whereas firm size has been found to have little predictive power when controlling for age. Exclusively using size criteria to target tax incentives therefore is an inefficient - if not ineffective - way of promoting growth and job creation.

As only a small group of young and upcoming enterprises accounts for the bulk of net job creation, some countries try to target SME tax incentives more specifically at these firms. France, Malta and Portugal, for example, offer special reliefs for newly founded SMEs and their shareholders. ${ }^{96}$ Entry incentives, however, are also unlikely to have the intended effect on job creation because even among new firms the targeted high-growth firms only represent a minority. In fact, the entrepreneurship literature has identified two groups of entrepreneurs: On the one hand, there is the small group of progressive entrepreneurs with innovative ideas who enter the market to actively seize business opportunities, while on the other hand, there is the vast majority of defensive entrepreneurs who are mostly made up of passive followers, overoptimistic gamblers and escapees from unemployment. The latter group usually does not generate much growth and does not even aspire to do so. ${ }^{97}$ Hence, the targeting of high-growth firms creating new jobs is inadequate even when using a combination of size and age-related eligibility criteria.

Furthermore, progressive entrepreneurs are unlikely to need tax incentives to start their businesses anyway. Intuitively, the marginal entrepreneur, i.e., the entrepreneur who starts a business only due to the availability of tax incentives, most likely is a defensive founder rather than a progressive entrepreneur. Somebody seeking to exploit an innovative idea or a novel business opportunity would probably engage in the venture irrespective of available reliefs and subsidies. The start-up decision of less competent and less ambitious entrepreneurs, in contrast, is more likely to be impacted by tax reliefs. ${ }^{98}$ Hence, start-up

\footnotetext{
${ }^{95}$ See Birch (1981) pp. 8 f.; Birch/Medoff (1994) p. 162; Geroski (1995) pp. 422 f.; Acs/Mueller (2008) pp. 85 ff.; NESTA (2009) pp. 1 ff.

${ }^{96}$ See Annex 1.

${ }^{97}$ See Evans/Leighton (1989) pp. 528 ff.; Toninelli/Vasta (2010) pp. 74 ff.; Hurst/Pugsley (2011) pp. 92 ff.

${ }^{98}$ See Johnson (2004) pp. 442 ff.; Shane (2009) pp. $145 \mathrm{ff}$.
} 
incentives tend to encourage the "wrong" entrepreneurs to start a business while the "right" ones receive tax benefits although they would have invested anyway. And even if some of the "right" taxpayers were lured into self-employment, there is no apparent reason to explicitly restrict start-up benefits to small and micro businesses. ${ }^{99}$

Tying eligibility for SME tax incentives to increased employment (or at least to the retention of existing jobs) is another approach to target high-growth businesses more accurately. ${ }^{100}$ Obviously, such incentives could induce firms to employ people they would not have hired in the absence of the relief. It is questionable, though, if job creation per se is an appropriate policy goal. A growing economy in which the allocation of resources is not impeded by market failure usually generates enough jobs on its own. ${ }^{101}$ Hence, policy-makers should rather focus on the provision of a neutral and investment-friendly business environment that keeps the obstacles to firm growth to a minimum. ${ }^{102} \mathrm{SME}$ tax incentives, however, achieve the opposite. They discourage growth if eligibility is restricted by fixed turnover, asset or employment thresholds and - in the case of incentives tied to employment numbers - they distort the choice of input factors (capital vs. labor), which may hamper the overall competitiveness of a country's economy. ${ }^{103}$ And even if the above arguments are neglected because employment is fostered for social rather than for economic reasons, the restriction of tax incentives to small enterprises again does not make sense unless jobs in large enterprises are considered to be inferior. ${ }^{104}$

Altogether, job creation does not constitute a valid argument for SME tax incentives. If additional employment is sought, the problem should be addressed directly, e.g., through reduced labor costs. Size, however, is not an accurate indicator of a firm's propensity to hire new employees. SME tax incentives are therefore neither efficient nor effective in generating new jobs. They benefit many businesses that are not intended to benefit and introduce more complexity and new distortions to the tax system, thereby impeding rather than fostering

\footnotetext{
${ }^{99}$ In fact, the probability of survival increases in the size of a start-up. Start-up incentives exclusively available for small and micro businesses may thus tend to benefit those start-ups that cannot survive on a level playing field. See Santarelli/Vivarelli (2002) pp. $43 \mathrm{ff}$.

${ }^{100}$ Increased employment as an additional eligibility criterion or as a calculation basis for SME tax incentives can currently be found in France, Hungary, Poland and Spain. See Annex 1.

${ }^{101}$ See de Rugy (2005) p. 18; Gravelle/Lowry (2012) pp. 14 f.

102 See Diamond/Mirrlees (1971a) pp. 8 ff.; Diamond/Mirrlees (1971b) pp. 261 ff.; Maula/Murray/Jääskeläinen (2007) pp. $58 \mathrm{ff}$.

${ }^{103}$ See de Rugy (2005) p. 15.

${ }^{104}$ Empirical evidence rather suggests the opposite, though. Jobs in large enterprises are more durable, pay higher wages and include more fringe benefits, health insurances and retirement plans. See Brown/Hamilton/Medoff (1990) pp. 29 ff.; Dunne/Roberts (1991) pp. 216 ff.; Davis/Haltiwanger/Schuh (1996b) pp. 78 ff.; Dushi/Iams/ Lichtenstein (2011) pp. 53 ff.; Kaiser Family Foundation and Health Research \& Educational Trust (2016) p. 2.
} 
economic growth. The design of many of the currently available regimes, i.e., reliefs in the form of output-based incentives for which eligibility is explicitly restricted by absolute thresholds on turnover, assets and employment, even reinforces these problems.

\subsubsection{Innovativeness}

The innovativeness of the small business sector is another argument regularly brought up to support SME tax incentives. Evidently, innovation is a major driver of economic growth. The introduction of new products and technologies is key to raising general productivity. ${ }^{105}$ It promotes market competition, fosters the development of new markets and triggers the destruction of existing ones. ${ }^{106}$ SME tax incentives could thus be warranted if they spark additional SME activity that results in additional innovations and the exploitation of innovations in the form of successful and sustainable businesses to the benefit of the economy as a whole.

Similarly to R\&D incentives, the innovation-based rationale for SME reliefs builds on the occurrence of market failure in the form of spillover effects. Such spillovers arise because the originator of an innovation often cannot exclude others from the benefits of the innovation, e.g., due to product imitation or the transfer of personnel. ${ }^{107}$ As a consequence, the economy as a whole benefits more than the innovator alone. ${ }^{108}$ When making the decision to invest and innovate, however, investors only take their personal returns into account. This leads to a suboptimal level of resources allocated to innovative activities and ultimately to social welfare losses. ${ }^{109}$ Whether SME tax incentives represent an effective countermeasure against this market failure depends on their ability to spur additional SME activity that generates more innovations and positive spillovers than the investments that would have been undertaken in the absence of the incentives.

With regard to the relationship of firm size and innovativeness, there are two opposing views. While neo-classical theories suggest small firms to be particularly innovative as fierce competition and a lack of economies of scale force them to generate competitive

\footnotetext{
${ }^{105}$ See Solow (1956) pp. 65 ff.; Romer (1986) pp. 1002 ff.; Lucas (1988) pp. 3 ff.; Romer (1990) pp. S71 ff.; OECD (2001b) pp. $51 \mathrm{ff}$.

${ }^{106}$ See Bresnahan/Greenstein/Henderson (2012) pp. 203 ff.; Bleda/Morrison/Rigby (2013) pp. 115 ff.

${ }^{107}$ See Arrow (1962) pp. 609 ff.; Spengel/Müller-Rees/Endres/Harhoff/Heinemann/Hellwig/Hüther/Regierer/ Schön/Stein (2009) pp. 4 ff.

${ }^{108}$ For R\&D activities - which are closely related to innovations - the overall rate of return for society is estimated to be on average twice as high as the internal rate of return of the enterprise performing the R\&D (or even higher). See Baghana/Mohnen (2009) pp. $98 \mathrm{ff}$.

${ }^{109}$ See Adams/Jaffe (1996) pp. 700 ff.; Stiglitz (2015) p. 4.
} 
advantages through product differentiation, the Schumpeterian view assumes large enterprises to be more innovative because only they have the market power to fully reap the benefits emanating from innovations. ${ }^{110}$ According to the latter view, large firms are more suited to introduce innovative products to the market due to better management skills and better financial resources. They use previous research more efficiently and derive advantages from a superior division of labor. ${ }^{111}$ Moreover, their size allows them to better absorb the high share of fixed costs associated with innovative activities and to adequately diversify the related risks. ${ }^{112}$ Small businesses, on the other hand, exhibit easier and quicker decision-making due to leaner organizational structures. They can react faster to customer demands, which is an important advantage in recognizing and pursuing new ideas and business models. Furthermore, small firms and their employees may be more aware and more excited about minor innovations that are overlooked by large organizations. ${ }^{113}$

Ultimately, it is an empirical question whether SMEs' advantages in innovative activities outweigh their disadvantages and whether they are indeed more innovative than large enterprises. Existing evidence, however, does not give a clear answer to this question. While early empirical research by Horowitz (1962), Hamberg (1964) and Scherer (1965) rather suggests larger firms to be more innovative, Bound et al. (1984), Mowery (1983) and Cohen (1987) do not find a clear link between firm size and the propensity to spend on R\&D. ${ }^{114}$ The results of these early studies need to be considered with caution, though, because they feature limited samples predominantly consisting of large enterprises. It is therefore questionable if the results allow valid conclusions about the SME sector. Moreover, the measurement of innovation is not trivial and results have been found to be highly dependent on the specific measures of innovation that are referred to. ${ }^{115}$ As a consequence, even the large body of more recent empirical literature does not come to a clear conclusion whether small or large enterprises are more innovative. Shefer and Frenkel (2005), Akcigit (2009), Park (2011) and Wolfe (2012), for example, observe small firms to spend more on

\footnotetext{
${ }^{110}$ See Dasgupta/Stiglitz (1980) pp. 260 ff.; Reinganum (1985) pp. 275 ff.; Schumpeter (2010) pp. 71 ff.

${ }^{111}$ See Acs/Audretsch (1990) pp. 54 f.; Verworn/Lüthje/Herstatt (2000) pp. 11 ff.

112 See Galbraith (1956) p. 87.

${ }^{113}$ See Scherer (1980) p. 414 f.; Nooteboom (1994) pp. 333 ff.; Hoffmann/Parejo/Bessant/Perren (1998) pp. 44 f.; OECD (2009b) p. 120.

${ }^{114}$ See Horowitz (1962) pp. 298 ff.; Hamberg (1964) pp. 62 ff.; Scherer (1965) pp. 12 ff. For further evidence, also see Comanor (1967) pp. 639 ff.; Scherer (1980) pp. 407 ff.; Meisel/Lin (1983) pp. 28 ff.; Mowery (1983) pp. 953 ff.; Bound/Cummins/Griliches/Hall/Jaffe (1984) pp. 21 ff.; Cohen/Levin/Mowery (1987) pp. 543 ff.

${ }_{115}$ See Baldwin/Scott (1987) pp. 63 ff.; Acs/Audretsch (1990) pp. 9 ff.; Zimmermann/Andres (2001) pp. 532 f.; Fell/Hansen/Becker (2003) pp. 348 f.; Kock (2007) pp. 1 ff.; Schultz/Salomo/Talke (2013) p. 94.
} 
R\&D whereas Hong et al. (2016) find the opposite. ${ }^{116}$ Results with regard to innovative outputs - measured as the number of new processes, products or services - are equally contradictory. While Pavitt et al. (1987), Kleinknecht et al. (1993), Cogan (1993), Santarelli and Piergiovanni (1996), Stock et al. (2002) and Hong et al. (2016) attest a negative link between firm size and the number of innovations, Damanpour (1992), Camisón-Zornoza et al. (2004) and Laforet $\left(2008,2009\right.$, 2013) report a positive rapport. ${ }^{117}$ Tsai (2005) and Tsai and Wang (2005), on the other hand, assume a U-shaped relation between firm size and R\&D productivity. ${ }^{118}$ Studies not finding a clear relation between firm size and innovativeness include Acs and Audretsch (1988), Symeonidis (1996), Wakasugi and Koyata (1997), Tether (1998), Freel (2005), Hausman (2005), Lee and Sung (2005), Laforet and Tann (2006) and Baregheh et al. (2016). ${ }^{119}$

Altogether, the diversity of empirical results suggests that there is no linear, monotonic relationship between firm size and innovativeness applying across all industries, size classes and countries. Innovation-related arguments do therefore not warrant the use of tax incentives basing eligibility solely on size criteria. And even if small firms were - on average - slightly more innovative than large enterprises, this does not mean that firm size is a good indicator of innovativeness because it is not the average investor (or investment) that matters but the marginal one. It is the investor in need of a tax incentive to actually make the investment who is relevant for the incentive's effectiveness. Given the skewed distribution of firms with regard to innovation ${ }^{120}$ and the small number of actually innovative SMEs, ${ }^{121}$ the marginal SME investment can be assumed to not show the required positive attributes with respect to innovation and spillovers.

\footnotetext{
${ }^{116}$ See Shefer/Frenkel (2005) pp. 25 ff.; Akcigit (2009) pp. 1 ff.; Park (2011) pp. 1 ff.; Wolfe (2012) pp. 2 f.; Hong/Oxley/McCann/Le (2016) pp. 5379 ff.

${ }^{117}$ See Pavitt/Robson/Townsend (1987) pp. 297 ff.; Kleinknecht/Reijen/Smits (1993) pp. 42 ff.; Cogan (1993) pp. 113 ff.; Santarelli/Piergiovanni (1996) pp. 689 ff.; Stock/Greis/Fischer (2002) pp. 537 ff.; Hong/ Oxley/McCann/Le (2016) pp. 5379 ff.; Damanpour (1992) pp. 375 ff.; Camisón-Zornoza/LapiedraAlcami/Segarra-Ciprés/Boronat-Navarro (2004) pp. 331 ff.; Laforet (2008) pp. 753 ff.; Laforet (2009) pp. 188 ff.; Laforet (2013) pp. $490 \mathrm{ff}$.

${ }^{118}$ See Tsai (2005) pp. 795 ff.; Tsai/Wang (2005) pp. 966 ff.

${ }^{119}$ See Acs/Audretsch (1988a) pp. 197 ff.; Symeonidis (1996) pp. 5 ff.; Wakasugi/Koyata (1997) pp. 383 ff.; Tether (1998) pp. 725 ff.; Freel (2005) pp. 123 ff.; Hausman (2005) pp. 773 ff.; Lee/Sung (2005) pp. 914 ff.; Laforet/Tann (2006) pp. 363 ff.; Baregheh/Rowley/Hemsworth (2016) pp. 768 ff. Inconclusive evidence also exists with regard to the correlation of firm size and the quality of innovations. See Akcigit (2009) pp. 1 ff.; Tether (1998) pp. $725 \mathrm{ff}$.

${ }^{120}$ See Baumol (1990) pp. 893 ff.; Hurst/Pugsley (2011) pp. 92 ff. Schultz/Salomo/Talke (2013) p. 94.;

${ }^{121}$ Hurst and Pugsley (2011), for example, only find $17.3 \%$ of American small businesses to generate any intellectual property within the first four years of their existence. Even more astonishingly, less than $20 \%$ of the business founders in their sample expect R\&D to make up a considerable share of their expenses and only $34.9 \%$ of the entrepreneurs think that they a have a good business idea when starting their businesses. Piergiovanni and Santarelli (2006) confirm these trends as they estimate only $4.7 \%$ of new Italian businesses - which tend to be small - to be innovative. See Piergiovanni/Santarelli (2006) p. 268; Hurst/Pugsley (2011) p. 93.
} 
As firm size is an inaccurate proxy for innovation, other eligibility should be referred to when targeting tax incentives at innovative investments and investors. In this respect, $R \& D$ activity is the obvious nexus. The link between R\&D and innovativeness is much closer than the link between firm size and innovativeness. ${ }^{122} \mathrm{R} \& \mathrm{D}$ tax incentives are therefore the superior instrument compared to SME-specific measures. Due to superior targeting, they are more effective and more efficient in generating innovations and positive spillovers. ${ }^{123}$

Given the adequacy of tax incentives supporting R\&D investments, the most interesting question with regard to small and medium-sized enterprises is whether to restrict eligibility for R\&D tax incentives to SMEs. In other words, is there a valid, economically sound justification for excluding large enterprises from $R \& D$ incentives or offering more generous reliefs for SMEs? In the European Union, there are currently several countries providing $R \& D$ incentives exclusively for SMEs or $R \& D$ incentives that are more generous for SMEs. ${ }^{124}$

There are indeed arguments in support of a more pronounced need for R\&D tax incentives among SMEs than among large enterprises. First of all, small entities have been found to benefit less from direct subsidies and funding schemes for R\&D projects than large businesses. Most likely, this is due to the regulatory burden associated with the application for such schemes. ${ }^{125}$ Tax incentives being especially generous for SMEs could correct for this

\footnotetext{
${ }^{122}$ Providing necessary knowledge, R\&D often is the pre-requisite for the successful introduction of new products and technologies. However, R\&D activities - even successful efforts - are not a perfect proxy for innovativeness either. The results of $R \& D$ activities still require entrepreneurial efforts and the accumulation of other production factors such human and physical capital to transform the knowledge into marketable products and services. Moreover, innovation is not necessarily based on R\&D. Especially in service sectors, innovations are mostly non-technological and related to a comparatively small amount of R\&D. Gaillard-Ladinska et al. (2015) even assume R\&D tax incentives not to be a determinant of a country's innovativeness. Overall, however, R\&D spending still appears to target innovative enterprises much more precisely than firm size. See Acs/Audretsch (1988b) pp. 681 ff.; Zimmermann/Andres (2001) pp. 532 ff.; Braunerhjelm (2012) pp. 286 ff.; Trigo (2013) pp. 48 ff.; Braunerhjelm (2014) pp. 11 ff.; Gaillard-Ladinska/Non/Straathof (2015) p. 25.

${ }^{123}$ Spengel et al. (2009) estimate a $1 \%$ decrease of the user cost of capital to induce a $1 \%$-increase in R\&D investments. (Some other studies report lower elasticities of R\&D investments, though.) Moreover, the average overall rate of return on R\&D investments (for the economy as a whole) is estimated to be about twice as high as the rate of return the enterprise performing the R\&D can incur. See Spengel/MüllerRees/Endres/Harhoff/Heinemann/ Hellwig/Hüther/Regierer/Schön/Stein (2009) pp. 15 ff.

${ }^{124}$ These countries include Malta, the Netherlands (only start-ups) and the United Kingdom. In addition, France grants immediate refunds instead of carry forwards on the R\&D. The UK uses an extended definition of SMEs. It includes thresholds that are twice as high as under the standard definition of medium-sized enterprises given by the European Union. Further countries (Finland, France, Italy, the Netherlands and Portugal) incorporate absolute caps for available reliefs which naturally affects large taxpayers more than SMEs and therefore represents an indirect advantage for small entities. See the country reports in Annex 1 for more detailed descriptions of the regimes.

${ }^{125}$ The administrative burden related to the application of R\&D tax incentives, however, can also be substantial for small businesses and absorb some of the benefits incurred. See Derregia/Chittenden (2007) p. 7.
} 
imbalance as they are less prone to selection bias than direct subsidies. ${ }^{126}$ Even more importantly, small businesses are on average subject to more severe financing constraints and may therefore require tax reliefs in early investment stages more urgently. ${ }^{127}$ This is especially relevant for $R \& D$ projects as they are often more risky and include fewer tangible assets that can be liquidated if the project fails. ${ }^{128}$ As a consequence, obtaining capital becomes even more difficult for SMEs engaging in R\&D. ${ }^{129}$ For them, the respective projects often account for a large share of their overall business activity and can therefore hardly be compensated for by other successful projects in the event of failure. Large entities, in contrast, are better suited to diversify the related risks due to the large number of investment objects they are usually engaged in. ${ }^{130}$ Financing constraints are thus less likely to prevent them from investing in $R \& D$. In line with these considerations, $R \& D$ investments have actually been found to be more responsive to tax incentives in SMEs than in large enterprises. Moreover, deadweight losses arising from R\&D incentives are higher for large enterprises. ${ }^{131}$ And as the principle of efficiency requires the minimization of support for projects that would also be undertaken in the absence of tax incentives, restricting R\&D tax incentives to SMEs may be warranted.

The restriction of eligibility for R\&D incentives to SMEs, however, also causes additional costs. Above all, restrictions complicate the tax code and induce additional compliance and administrative costs. Furthermore, the implicit taxation of growth is a problem arising from the limitation of eligibility to SMEs. If incentives are not available beyond certain size thresholds, taxpayers are discouraged from growing and exceeding the respective thresholds. ${ }^{132}$ With regard to R\&D projects (which tend to be high-risk, high return ventures), this may lead to the absurd situation of enterprises being better off if the projects are not too successful. In general, implicit taxes on growth are especially dangerous in sectors emphasizing R\&D and innovation because innovation - as mentioned before - is closely related to growth. Conceptually, it would be inconsistent to provide incentives encouraging economic growth through innovation but also penalizing the firms that actually grow. Lastly,

\footnotetext{
${ }^{126}$ In addition, they show superior properties with regard to investment neutrality, i.e., they are less prone to distorting the choice R\&D projects undertaken. See Spengel (2016) pp. $409 \mathrm{ff}$.

${ }^{127}$ See Section 4.1.4 for a detailed discussion of the financing constraints faced by SMEs.

${ }^{128}$ See Stiglitz/Weiss (1981) pp. 393 ff.; Hsu (2004) pp. 1805 ff.; Hall/Lerner (2010) pp. 613 ff.; KfW Research (2016) pp. $8 \mathrm{f}$.

${ }^{129}$ SMEs and start-ups have experienced even more significant problems to finance R\&D and other innovative activities since the economic crisis. See North/Baldock/Ullah (2013) pp. 244 ff.; OECD (2013b) pp. 22 ff.; OECD (2015) pp. $30 \mathrm{ff}$.

${ }^{130}$ See Honold (2015a) pp. $1 \mathrm{ff}$.

${ }^{131}$ See Haegeland/Moen (2007) pp. 40 ff.; Baghana/Mohnen (2009) pp. 91 ff.; Castellacci/Lie (2015) pp. 819 ff.

${ }^{132}$ See Holtz-Eakin (1995) p. 393.
} 
incentives exclusively available for SMEs obviously deteriorate the investment neutrality of the tax system. Investments by SMEs are favored and therefore need to generate lower pre-tax rates of return to be undertaken. This can lead to a misallocation of human and physical capital which could be especially harmful in the knowledge-intense R\&D sector where resources (e.g., qualified researchers) are scarce. ${ }^{133}$

Summing up, R\&D tax incentives are the more efficient and effective instrument to spur innovative activity compared to SME tax incentives. The above-average innovativeness of SMEs - which is not even free of doubt considering the current body of empirical work does not support the implementation of generally applicable SME incentives. ${ }^{134}$ Targeting R\&D tax incentives at SMEs, however, may have its merits as the efficiency of the incentives is likely to increase and the losses in tax revenue to decrease. The benefit of targeting SMEs need to be carefully weighed against the costs, though. Moreover, incentive designs need to avoid explicit size restrictions (i.e., eligibility thresholds on turnover or the number of employees). Instead, maximum absolute reliefs on input-based measures should be applied to target smaller entities. This practice is comparatively easy to implement as no size criteria have to be documented by taxpayers (nor controlled by tax administrations). Moreover, absolute caps on available reliefs prevent that firm growth is directly discouraged. ${ }^{135}$ At the same time, they provide policy-makers with an easy-to-handle instrument to control the revenue losses. ${ }^{136}$

\subsubsection{Financing Constraints}

The occurrence of market failure and related distortions can be a valid justification of tax incentives. The mere existence of market failure, however, does not suffice. Tax incentives also have to be effective in addressing the market failure and they should be the most efficient instrument to do so in order to represent a sensible policy instrument. ${ }^{137}$

\footnotetext{
${ }^{133}$ See European Commission (2007a) pp. 22 ff.; Erkal/Scotchmer (2009) pp. 4 ff.; EFI (2012) pp. 61 ff.; European Commission (2014) pp. 16 ff.

${ }^{134}$ In fact, general investment incentives may even have detrimental effects on R\&D investments as required capital is encouraged to be spent on other assets and activities. See Manly/Thomas/Schulman (2015) p. 115.

${ }^{135}$ Intertemporal distortions, i.e., firms delaying investments to stay within the maximum, may be a side effect, though. As an alternative to thresholds restricting maximum eligible R\&D expenditures, input-based incentives could also apply regressive rates in the determination of allowances or tax credits. Under these regimes, the preferential tax treatment of expenditures would not run out beyond the threshold but be granted at a smaller scale.

${ }^{136}$ See European Commission (2015b) p. 151.

${ }^{137}$ See Crawford/Freedman (2010) pp. $1077 \mathrm{ff}$.
} 
Besides positive spillovers, asymmetric information is another market failure regularly associated with SMEs that may legitimize the usage of specifically targeted tax incentives. With regard to small businesses, harmful asymmetry primarily occurs between business insiders (i.e., owners and managers) and outside providers of capital. ${ }^{138}$ Naturally, an information gap between both parties exists for all kinds of businesses as insiders (almost) always have superior knowledge of their firms compared to external stakeholders. ${ }^{139}$ The information gap and related problems in the acquisition of financing are particularly pronounced in the SME sector, though. ${ }^{140}$ The reasons hereof are numerous. First of all, retrieving information on SMEs is more expensive for outsiders as they are usually not in the focus of capital market analysts and information is not as easily available. ${ }^{141}$ Their securities are usually less frequently traded than those of larger entities and the information conveyed by market pricing is likely to be less timely and relevant. ${ }^{142}$ The problem is further aggravated by the fact that many SMEs do not have to produce audited financial statements and that they are subject to fewer obligations to publicly disclose financial data. Obtaining information thus becomes more laborious. ${ }^{143}$ And even if SMEs provide financial statements and other data on their businesses, the quality is often insufficient due to inadequate business skills, lower key internal reporting systems, insufficient self-presentation and a lack of intrinsic motivation to disclose information. ${ }^{144}$ The overlap of ownership and management in many small businesses is another factor impacting on outsiders' information deficits as it magnifies owners' head start in knowledge and their leeway in sharing the information they possess. Moreover, the finances of firms and their owners are more likely to mingle in owner-managed SMEs than in larger entities. The picture for outside investors thereby becomes even more nebulous. ${ }^{145}$

Theory suggests asymmetric information to induce adverse selection, in particular with regard to debt financing. As creditors are not able to adequately adjust interest rates to SMEs' individual characteristics and risks, they are likely to charge uniform interest rates that

\footnotetext{
${ }^{138}$ See Ennew/Binks (1995) pp. 57 ff.; Cressy (1996) pp. 1253 ff.; Hall/Hutchinson/Michaelas (2000) pp. 297 ff.; Hsu (2004) pp. 1807 ff.

${ }^{139}$ See Fazzari/Hubbard/Petersen (1988) pp. 200 ff.; Diamond (1991) pp. 689 ff.; Audretsch/Elston (1997) p. 106.

${ }^{140}$ See Petersen and Rajan (1992) pp. 3 ff.; Berger/Udell (1998) pp. 613 ff.; Freel (2007) p. 25.

${ }^{141}$ See Tucker/Lean (2003) pp. $51 \mathrm{ff}$; Cassar (2004) pp. $266 \mathrm{ff}$.

${ }^{142}$ See Diamond/Verrecchia (1981) pp. $221 \mathrm{ff}$; Holmström/Tirole (1993) pp. $678 \mathrm{ff}$.

${ }^{143}$ See Chittenden/Hall/Hutchinson (1996) p. $61 \mathrm{f}$.

${ }^{144}$ See Mason/Harrison (2002) pp. 281 f.; Ball/Shivakumar (2005) pp. 83 ff.; Clark (2008) pp. 257 ff.; Ettredge/Johnstone/Stone/Wang (2011) pp. 866 ff.; Tysiac (2012) pp. 38 ff.; Hope/Thomas/Vyas (2013) pp. 1715 ff.; Liu/Skerratt (2014) pp. 3 ff.; OECD (2014) p. 50. Empirical evidence also shows that even the voluntary use of accrual accounting and the disclosure of such accounts only have a limited effect on SMEs' ability to obtain loans from banks. See Cassar/Ittner/Cavalluzzo (2015) pp. $242 \mathrm{ff}$.

${ }^{145}$ See Aldrich/Cliff (2003) 573 ff.; OECD (2006) pp. 18 f.; OECD (2014) p. 50.
} 
tend to be disproportionate relative to the idiosyncratic risks of many SMEs. As a consequence, only "bad risks" obtain loans whereas "good risks" refrain from accepting credits. The banks, in turn, further raise interest rates if only bad risks remain and the process of adverse credit selection is reinforced. ${ }^{146}$ Additionally, asymmetric information leads to inadequate monitoring of lenders and potential problems of moral hazard when lenders are enabled to take excessive risks. Even more good risks would thereby be turned into bad risks and interest rates inflate even further. ${ }^{147}$ In the end, lending to SMEs may become so unattractive that lenders are not willing to provide funds and credits rationing becomes a substantial obstacle for business growth that is almost impossible to overcome for individual enterprises.

Empirical evidence suggests that the aforementioned problems indeed cause an insufficient provision of capital for at least some SMEs $^{148}$ and that the financing gap affects the formation and the development these SMEs. ${ }^{149}$ The true extent of the financing gap and its effects on social welfare are not clear, though. ${ }^{150}$ Especially in industrialized countries, the financing gap is mostly limited to a rather small group of SMEs that tend to be young, innovative and characterized by above-average growth aspirations and the ensuing increased capital needs. ${ }^{151}$ The large majority of established businesses, in contrast, appear to have sufficient access to funds. Debt financing in particular is perceived to be rather unproblematic as banks have increasingly adjusted their business models to the requirements of SME lending and financial innovations have helped to adjust for SME particularities. ${ }^{152}$

If tax incentives are intended to compensate for inadequate capital supply, their primary focus should therefore be on the group of innovative, high-growth and mostly young

\footnotetext{
${ }^{146}$ See Akerlof (1970) pp. 488 ff.; Stiglitz/Weiss (1981) pp. 393 ff.; Myers/Majluf (1984) pp. 187 ff.; Stiglitz/Weiss (1992) pp. 694 ff.; Lerner (1999) pp. $290 \mathrm{ff.}$

${ }^{147}$ See Stiglitz/Weiss (1981) pp. 393 ff.

${ }^{148}$ See Fazzari/Hubbard/Petersen (1988) pp. 200 ff.; Hyytinen/Väänänen (2006) pp. 323 ff.; TSO (2009) pp. 11 ff.; KfW Research (2016) p. 8; Donati (2016) pp. 1881 ff. Empirical evidence also suggests the financing gap to decrease in firm size within the group of SMEs, i.e., micro enterprises have greater difficulties to obtain funds than small and medium-sized enterprises. See IES (2005) pp. $140 \mathrm{ff}$;; BIS (2015) pp. $74 \mathrm{ff}$.

${ }^{149}$ See Evans/Jovanovic (1989) pp. 808 ff.; Evans/Leighton (1989) pp. 525 ff.; Cooper/Gimeno-Gascon/Woo (1994) pp. 371 ff.; Holtz-Eakin/Joulfaian/Rosen (1994a) pp. 53 ff.; Holtz-Eakin/Joulfaian/Rosen (1994b) pp. 334 ff.; Blanchflower/Oswald (1998) pp. 26 ff.; EFI (2012) pp. 85 ff.; Donati (2016) pp. 1881 ff.

${ }^{150}$ See Hughes (1997) pp. 151 ff.; OECD (2006) p. 26; Crawford/Freedman (2010) pp. $1078 \mathrm{f}$.

${ }^{151}$ See Audretsch/Lehmann (2004) pp. 340; IES (2005) pp. 138 ff.; Freel (2007) pp. 23 ff.; TSO (2009) pp. 16 ff.; Stucki (2013) pp. 1 ff.; Duarte/Matias Gama/Esperanca (2016) pp. 693 ff.

${ }^{152}$ See Edwards (2000) p. 5 ff.; OECD (2006) p. 49; Robb/Robinson (2014) pp. $161 \mathrm{f}$. The deterioration of financing conditions due to the economic crisis, however, has been found to be especially harsh for SMEs. Moreover, a lack of debt financing for SMEs still represents a more significant problem in less developed emerging markets. See OECD (2006) pp. 20 ff.; TSO (2009) pp. 11 ff.; OECD (2014) p. 49; European Investment Bank (2015) pp 4 ff.
} 
SMEs. These businesses usually have the highest demand for capital ${ }^{153}$ but also feature some characteristics complicating the acquisition of funds. ${ }^{154}$ Debt financing and other traditional means of finance are usually of limited relevance for them due to the risks associated to their ventures. For outsiders, there is typically no or only little historic information to be evaluated and the business models as well as the management skills of owners and managers are unproven. ${ }^{155}$ Moreover, start-ups often incur losses in their first years and many investors prefer to only invest in more advanced stages of development. ${ }^{156}$ The lack of assets to pledge as collateral is another problem of newly founded SMEs that exacerbates obtaining capital. ${ }^{157}$ The problem is particularly severe for innovative start-ups centered around R\&D activities. They usually focus on the generation of intangibles that cannot or only hardly be liquidated if the venture fails. For investors, in particular creditors, the riskiness thereby increases significantly. As a consequence, they often refrain from providing capital and many innovative ventures have to rely on self-financing and outside risk capital financing more than other SMEs. ${ }^{158}$

Given this misallocation of capital, the question at hand is whether SME tax incentives do adequately address the problem. Interestingly, the group of SMEs most affected by financing constraints appears to be the same dynamic group that also accounts for disproportionally high rates of innovation and job creation. So there is a certain kind of SME which generates the positive spillovers sought by policy-makers and at the same time suffers the most from underinvestment due to asymmetric information. As already discussed, these firms only represent a very small fraction of the SME sector, though, and providing relief to enterprises of a certain size therefore constitutes as very inefficient way of fostering investments in the innovative, high-growth SMEs. There are simply too many other small and medium-sized entities not falling into this category and a more accurate targeting with the help of additional eligibility criteria - as currently implemented for numerous input-based

\footnotetext{
${ }^{153}$ See North/Baldock/Ullah (2013) pp. 244 ff.

${ }^{154}$ See Gompers/Lerner (2001) pp. 154 ff.; Audretsch/Lehmann (2004) pp. 340 ff.; Hsu (2004) pp. 1805 ff.

${ }^{155}$ See Audretsch/Lehmann (2004) pp. 340 ff.; Revest/Sapio (2012) pp. 179 ff.; OECD (2014) p. 50.

${ }^{156}$ The number of potential sources of finance typically increases in firm age for start-ups and young ventures. During the seed stage, owner and insider equity as well as debt are the primary sources of finance. In the following, during the early stage and the expansion stage, outside equity by venture capital investors and business angels becomes more relevant as the uncertainty about the market potential of the products and services decreases. Debt financing usually remains a source of finance through all phases of development of young enterprises. See TSO (2009) p. 8.

${ }^{157}$ See Cowling/Mitchell (1997) pp. 430 ff.; Vogel/Adams (1997) p. 22 ff.; Duarte/Matias Gama/Esperanca (2016) pp. $693 \mathrm{ff}$.

${ }^{158}$ Even if successful, the results of R\&D activities can only by capitalized in the late stages of the R\&D process. This is problematic with regard to leverage ratios and other financial indicators that are crucial in obtaining capital. See Brown/Fazzari/Petersen (2009) pp. 151 ff.; Revest/Sapio (2012) pp. 179 ff.; Honold (2015b) pp. 197 ff.; Zimmermann (2015) p. 184.
} 
schemes - is highly problematic as well. The additional criteria are not very accurate indicators either, enhance the complexity of the schemes and introduce further distortions to the neutrality of the tax code.

In addition to being inefficient, the majority of currently available SME tax incentives also bear the risk of being ineffective in providing relief to the targeted group of young and innovative high-growth enterprises. Above all, special tax rates for SMEs, the most commonly used and most impactful form of SME tax incentives, are inept as they only take effect when investments generate positive returns, i.e., after the actual investment has been made and the information asymmetry causing financing constraints has been cut back significantly. Input-based tax incentives, in contrast, could provide substantial support to businesses confronted with an insufficient supply of capital. If designed appropriately, i.e., if refunds are granted, they are effective in the early stages of investments when returns are often low or even negative. Moreover, tying the relief to the size of investments ensures a better targeting of enterprises with growth aspirations. ${ }^{159}$ In practice, however, refunds are rarely granted and even carry forwards are regularly limited. Moreover, the reliefs actually provided by input-based regimes are rather small compared to the savings incurred on special tax rates. It is thus questionable, in how far they really incentivize additional investments showing the intended favorable attributes and in how far they provide unnecessary relief to SME investments that would have been undertaken anyway and in large parts are not affected by financing constraints. ${ }^{160}$

Besides special tax rates and input-based incentives on the firm level, shareholderlevel reliefs are another instrument that aims at providing eligible businesses with additional funds. They grant preferential tax treatment of dividends and capital gains from SME investments. Hence, such investments require a lower pre-tax rate of return to meet the expected after-tax rate of return. ${ }^{161}$ Investor-level incentives thereby seek to induce more external equity to be invested in the SME sector. Given that young enterprises often need to resort to risk capital from outside equity holders, shareholder-level reliefs could indeed be an effective instrument to close the financing gap of SMEs. On the other hand, investor-level incentives for SMEs could have adverse effects on capital allocation instead of improving it if

\footnotetext{
${ }^{159}$ Input-based incentives, however, feature the risk of also supporting mere replacement investments. Moreover, they may distort investment decisions in favor of short-lived assets and - if only certain assets or activities are eligible - in favor of certain kinds of investments that are deemed support-worthy. See Zee/Stotsky/Ley (2002) pp. $1504 \mathrm{f}$.

${ }^{160}$ See de Meza (2002) pp. F17 ff.; Nanda (2010) pp. 1 ff.

${ }^{161}$ See OECD (2009a) p. 104.
} 
the additional capital invested in the SME sector is withdrawn from more efficient alternative investments in large enterprises. ${ }^{162}$ Given that shareholder reliefs for private investors generally face the same problems related to targeting the right SME as firm-level measures, this kind of unintended capital reallocation is not unlikely. Shareholder-level incentives, however, provide the possibility of restricting the respective measures to venture capital funds and venture capital companies. The targeting of high-risk, high-growth firms is thereby relocated to the fund, which helps the accuracy as well as the collection costs incurred by tax administrations. ${ }^{163}$ The effectiveness of incentives for venture capital funds and companies, however, is only given if comparable entities (i.e., investment funds and investment companies) are not exempt from taxation anyway. ${ }^{164}$

Existing evidence also casts doubt on the effectiveness as well as the efficiency of shareholder-level incentives as research predominantly finds lower capital gains taxes to have positive albeit modest effects on the level of high-tech and early-stage venture investments. The amount of additional capital provided to SMEs could therefore be disproportionally small compared to the costs that are induced by market distortions and forgone tax revenues. ${ }^{165} \mathrm{In}$ addition, the supply of capital could not even be the main reason for financial constraints. Instead, the problem may stem from the demand side as business owners refrain from taking up capital in fear of diluted ownership and control or the restrictions emanating from covenants. ${ }^{166}$ Moreover, owners of SMEs and their managers may forfeit opportunities for financing due to their unawareness of potential sources of funds. ${ }^{167}$ Obviously, tax incentives do not at all address these demand-side issues nor do they eliminate the actual sources of SME-specific asymmetric information relating to financial reporting, the quality of business planning, financial management and governance systems.

As a last argument against the use of tax incentives in the prevention of underinvestment in SMEs, empirical work has - at least up to now - not clearly identified the extent to which financial constraints of SMEs are really caused by asymmetric information (i.e., market failure). SMEs' problems in acquiring funds could actually be the result of a

\footnotetext{
${ }^{162}$ See Klemm (2010) p. 324.

${ }^{163}$ See Mason/Harrison (2001) p. 667; OECD (2010b) p. 11.

${ }^{164}$ See Klemm (2010) p. 327.

${ }^{165}$ See Gompers/Lerner (1998) pp. 149 ff.; Keuschnigg/Nielsen (2003) pp. 175 ff.; Keuschnigg/Nielsen (2004) pp. 1011 ff.; Armour/Cumming (2006) pp. 596 ff.; da Rin/Nicodano/Sembenelli (2006) pp. 1699.

${ }_{166}$ Both problems affect SMEs more than large enterprises where ownership mostly is fragmented anyway and covenants are often less restrictive due to existing collaterals and better risk diversification. See Myers (1984) pp. 575 ff.; Hutchinson (1995) pp. 231 ff.; Cressy/Olofsson (1997) pp. 87 ff.; Berggren/Olofsson/Silver (2000) pp. 233 ff.; Howorth (2001) pp. 78 ff.; Oakey (2007) pp. 223 ff.; Mason/Kwok (2010) p. 270 f.; OECD (2010b) pp. $3 \mathrm{ff}$.

${ }^{167}$ See Van Auken (2001) pp. 240 ff.; Cressy (2006) pp. 106 f.
} 
functioning market mechanism simply identifying alternative investments to be superior. ${ }^{168}$ In fact, capital markets have been found to function quite well even in the presence of imperfect information while the investment readiness of start-ups has been asserted to be inadequate in many cases. ${ }^{169}$ So the government's ability to generate a more efficient equilibrium than the market by redistributing capital resources to SMEs is doubtful. Accordingly, research generally recommends to refrain from direct policy intervention to close the financing gap. ${ }^{170}$

Summing up, the problem of asymmetric information aggravates the acquisition of capital for SMEs more than for large enterprises, which puts them at a competitive disadvantage and is likely to induce suboptimal levels of welfare. The extent of the problem is not clear, though. ${ }^{171}$ In developed financial markets, evidence suggests the financing gap of SMEs to primarily occur for equity financing of innovative and young SMEs with a high potential for growth. These enterprises require the most funds but often cannot sufficiently resort to traditional instruments of financing due to the risk structure of their ventures. Using firm-level incentives like special tax rates, tax allowances or tax credits is subject to the same problems in targeting the right group of businesses that are already described in the previous sections. On the shareholder level, preferential taxation of dividends and capital gains from all kinds of SME investments seriously deteriorates the investment neutrality of the tax code. Most likely, this results in major distortions of capital allocation that would outweigh the benefits of reducing SMEs' financing gap. A restriction to venture capital investments would more accurately target the SMEs producing positive externalities but - depending on the group of eligible investors - either the effectiveness or the practicality of this approach appears questionable. Financing constraints as a consequence of asymmetric information therefore do not constitute a strong argument for SME tax incentives either - especially in the way they are currently designed in the majority of countries.

\footnotetext{
${ }^{168}$ See IFS (2008) p. 227; Crawford/Freedman (2010) pp. $1078 \mathrm{f}$.

${ }^{169}$ See Mason/Harrison (1996) pp. 35 ff.; Feeney/Haines/Riding (1999) pp. 121 ff.; Mason/Kwok (2010) p. $269 \mathrm{ff}$. And even if there is a significant amount of market failure involved, a lack of knowledge about the extent makes the design of respective tax incentives almost impossible. Estimating the appropriate generosity of the relief would merely be a guessing game. See OECD (2009a) pp. $94 \mathrm{f}$.

${ }^{170}$ See Coombes/Storey/Watson/Wynarczyk (1991) pp. 723 ff.; Holtz-Eakin (1995) p. 393; Wallis/Dollery (1999) pp. 23 ff.; Cressy (2002) pp. F14 f.; OECD (2010a) pp. 8 ff.; DeHaven (2012) pp. 1 ff. Research generally suggests that policy-makers should be more concerned about allowing good risks to differentiate themselves from bad risks in the market by means of signaling. Distortions emanating from asymmetric information are thereby minimized. Shareholder-level tax incentives, instead, aggravate the signaling mechanism because they support bad risks (i.e., enterprises generating insufficient cash flows) in mimicking good risks. See Chen/Mintz (2011) pp. $19 \mathrm{f}$.

${ }^{171}$ See OECD (2013b) p. 29.
} 


\subsubsection{Socioeconomic Role of the SME Sector}

Besides the efficiency-driven rationale, there is also the view that socioeconomic considerations legitimize SME support. Following this line of thought, SMEs' role in expanding the middle class, in giving individuals the opportunity for economic advancement and in providing jobs for people who would find it difficult to obtain employment elsewhere makes them worthy of government assistance. ${ }^{172}$ U.S. sources describe businesses run by women, minorities and immigrants as being of particular importance in their communities because they do not only create job opportunities for the less educated but also help in building social networks and informal capital markets. These businesses are a possible entry into the labor market for the less educated and supply social benefits not obtainable for them otherwise. ${ }^{173}$ Moreover, small businesses are claimed to secure a diversity in locally available services and products that cannot be provided by the large players and chains and are therefore highly valued by the respective communities. ${ }^{174}$ Altogether, SME tax incentives may thus be justified by wider social issues.

The social benefits of SME activities, of course, are difficult to quantify. While empirical studies indeed find SMEs to provide a disproportionally large share of jobs to underqualified individuals, their impact on the diversity of available products and services is hardly measurable. Even if the prominent, socioeconomic role of small businesses is taken for granted, though, it is hard to make the case for tax incentives. If customers value the supply of certain products and services, for example, they will pay for them accordingly. There is no need for support through the tax system. With regard to employment and social advancement, it seems illogical to link support to firm size - at least if being the only eligibility criterion. If the hiring of certain employees is intended, then support should be awarded for hiring, not for being a small enterprise. In the end it boils down to the same line of argumentation already pursued in connection with the general role of the SME sector for the economy: Just because SMEs are important, they do not need to be provided with tax advantages. Just because they hire more underqualified people, they do not necessarily hire even more underqualified people when being subject to preferential tax rates. So if socioeconomic goals are the rationale behind SME tax incentives, support schemes should rather address these goals directly and not take firm size as a proxy for other firm characteristics. And under most circumstances,

\footnotetext{
${ }^{172}$ See Quadrini (1999) pp. 1 ff.; Guenther (2009) pp. 20 ff.; Headd (2010) p. 6; Gravelle/Lowry (2012) p. 11.

${ }^{173}$ See Brush/Hisrich (1999) pp. 111 ff.; Butler/Greene (1999) pp. 129 ff.

${ }^{174}$ See Anonymous (2011) p. 139 f.
} 
non-tax measures are probably the more effective, the more efficient and the more sustainable way of achieving socioeconomic goals. ${ }^{175}$

\subsection{Structural Disadvantages of SMEs Emanating from the Tax System}

\subsubsection{Incomplete Loss Offset}

As the commonly used non-tax arguments appear questionable as a justification of SME tax incentives, an adequate reasoning for providing such incentives may be rooted in the tax system itself. If the tax system discriminates against small and medium-sized firms, it creates inefficiencies in the allocation of resources and a level of investment in SMEs that is not optimal with regard to overall social welfare. Following this line of argumentation, tax incentives could serve as a compensation aiming at a minimization of the distortions induced by the tax system and at reducing the level of underinvestment in SMEs. In order to assess the validity of this argument, it needs to be examined if structural tax-induced disadvantages for SMEs really exist and if tax incentives are the appropriate measure to address them. The latter, of course, hinges on the effectiveness and efficiency of SME tax incentives, i.e., their ability to provide relief to those businesses negatively affected by structural discrimination of the tax system and to do so at reasonable costs.

Asymmetric treatment of profits and losses is a basic feature of modern income taxation. Taxpayers generally have to pay taxes on positive income - either corporate or personal income tax - whereas they do not receive any payments if they incur losses. If the government only participates in positive returns, taxation discriminates against investment projects bearing a greater risk of incurring losses. Income taxation may thus discourage risktaking. ${ }^{176}$ The problem is at least partly alleviated as businesses and their owners can offset losses against other positive income - either from other sources of income (e.g., employment income or capital income) or against income from past and future years. ${ }^{177}$ Not in all situations, however, taxpayers have positive income to be offset, which becomes even more likely as loss offsets are restricted. Hence, limitations to intra and inter-periodic loss offsets increase the danger of risk-taking being discouraged by income taxation. In practice, this may

\footnotetext{
${ }^{175}$ See Avi-Yonah (2006) pp. $22 \mathrm{ff}$.

${ }^{176}$ See Gentry/Hubbard (2005) pp. 87 ff.; Cullen/Gordon (2007) pp. $1479 \mathrm{ff}$.

${ }^{177}$ Corporations by definition only incur business income. Naturally, there is no other income than business income and they can only offset losses against other years' income. See IBFD (2015) pp. $47 \mathrm{ff}$.; Jacobs/Scheffler/Spengel (2015) p. 167.
} 
show on two levels: Either investors abstain from equity investments in risky ventures or the businesses themselves take fewer risks. ${ }^{178}$

The first question at hand is whether restrictions to loss offsets affect SMEs more severely than large enterprises. This would generally be the case if SMEs were more likely to incur losses. The AMADEUS data used to generate the model companies in Section 3 indeed indicates the return on equity to continuously increase in firm size. Moreover, SMEs are active in a smaller number of markets with a smaller number of products and services. Their business risks are less diversified and their incomes more volatile. ${ }^{179}$ Hence, SMEs should indeed be more affected by limited loss carry forwards and loss offsets than their larger counterparts. ${ }^{180}$ Even more than an "average SME", start-ups and young, high-risk ventures are prone to incur negative income as significant losses upfront are a usual occurrence for them. ${ }^{181}$ Upcoming start-ups are also particularly affected by loss trafficking rules as a buyout as well as the participation of venture capitalists and business angels potentially triggers the extinction of loss carry forwards. ${ }^{182}$ Moreover, time limits on carry forwards of four or five years as implemented in numerous countries ${ }^{183}$ may severely restrict start-ups' ability to deduct initial losses later on. ${ }^{184}$

Although SMEs indeed appear to suffer more from limited loss offsets, it is questionable if that really distorts investment decisions, i.e., leads to underinvestment in the SME sector. First of all, tax planning may at least alleviate the effects of the limitations, especially for start-ups who usually expect to incur upfront losses and should adjust accordingly. ${ }^{185}$ Secondly, investors have not been found to pay much attention to loss offset regulations in their investment decisions. ${ }^{186}$ But even if they did, the SME tax incentives analyzed in Section 3 are not the right measure to compensate for limited loss offsets because the link between firm size and the propensity to be affected by restricted loss offsets is only weak. The targeting of special tax rates or tax credits for SMEs would thus be poor if a compensation for limited loss offsets was intended. Moreover, the design of currently

\footnotetext{
${ }^{178}$ See Cooper/Franks (1983) p. 581; Krengel (2006) pp. 255 ff.

${ }^{179}$ See Moore/Garnsey (1993) p. 508; OECD (2006) p. 47; BIS (2015) p. 46.

${ }^{180}$ See OECD (2009a) p. 28.

${ }^{181}$ See Allen (2012) pp. $12 \mathrm{ff}$; EY (2013) pp. $13 \mathrm{ff}$.

${ }^{182}$ See Blöchle/Schmidt (2015) pp. 217 f.; Geberth (2016) p. M5.

${ }^{183}$ In corporate income taxation, eight countries apply limits of five years or less. Within the personal income tax, twelve countries have a cap of five years or less.

${ }^{184}$ See Chen/Lee/Mintz (2002) p. 17.

${ }^{185}$ See Blöchle/Schmidt (2015) pp. $216 \mathrm{ff}$.

${ }^{186}$ See Niemann (2004) p. 359 ff.; Jacob/Pasedag/Wagner (2011) p. 78.
} 
available SME incentives suggests that such a compensation is not the goal as special tax rates and non-refundable input-based incentives only benefit taxpayers with positive income.

If the issue of incomplete loss offsets is perceived to be a major problem for the SME sector, policy-makers should thus address the issue directly and reduce the respective restrictions - ideally for all kinds of companies. Alternatively, more generous provisions could be offered exclusively to new enterprises in order to prevent excessive losses in tax revenues. This would introduce another distortion to the tax system but at least firm age would be a more accurate indicator than firm size to target businesses that are likely to be actually affected by limited loss offsets. Moreover, it is an easy-to-track indicator which is less prone to misuse and accounting policies than firm size.

As already discussed, the focus of many policy-makers is on innovative high-risk, high-growth start-ups which generate positive externalities to the benefit of the economy as a whole. With regard to these enterprises, two restrictions to loss offsets and carry forwards should receive special attention. Above all, loss trafficking provisions represent an impediment as venture capital investors and business angels regularly acquire qualified shareholdings in high-growth start-ups. If loss trafficking rules are too restrictive, i.e., if they already kick in for minor ownership changes, the initial losses incurred by these businesses run the risk of being annihilated for tax purposes. ${ }^{187}$ This, in turn, might discourage or at least slow down the obtainment of outside capital by start-ups. Moreover, loss trafficking rules potentially depress the selling price upon exit for the founders of start-ups, thus making investments in start-ups less attractive. Secondly, start-ups may suffer from too restrictive time limits for carry forwards. If it takes them several years to generate net profits, four or five-year carry forwards may not suffice to fully offset the initial losses, especially if combined with limits on annual offsets (e.g., in Hungary and Poland). ${ }^{188}$

Summing up, incomplete loss offsets on carry forwards may indeed affect small and medium-sized enterprises more severely than large enterprises. ${ }^{189}$ Special tax rates, tax credits, allowances or depreciation schemes for SMEs, however, are not the appropriate countermeasures. Instead, it would be more effective and efficient to directly address the problem by granting more generous loss carry forwards and offsets. In particular, legislators should avoid loss trafficking rules that discourage investments in high-growth start-ups.

\footnotetext{
${ }^{187}$ See Blöchle/Schmidt (2015) pp. $217 \mathrm{f}$.

${ }^{188}$ See OECD (2009a) p. 90.

${ }^{189}$ For countries implementing absolute caps on annual loss offsets (France, Germany), the opposite could also be argued as the threshold of $€ 1$ million is more likely to be reached by large entities than by SMEs.
} 


\subsubsection{Debt Bias}

Most income tax systems treat equity and debt finance differently. While interest payments on debt are usually deductible from taxable income, dividend payments are not (or only to a limited extent). ${ }^{190}$ As a consequence, interest payments lower taxable business income and are exclusively taxed in the hands of the recipient of the interest whereas dividends are subject to double taxation on the corporate and on the shareholder level. For transparently taxed entities, the problem of double taxation does not exist because there is only one level of taxation. Disadvantages for equity financing, however, may arise if business and capital income are subject to different tax rates (progressive vs. proportional).

The discrimination against equity financing constitutes a structural disadvantage for SMEs if they have more problems to obtain debt financing than large entities and if they have more difficulties to effectively deduct interest payments from the tax base due to a lack of positive taxable income. In general, large firms may indeed be better positioned to obtain debt financing as they often represent better risks for creditors. They possess more assets that can serve as collateral and offer better risk diversification as a result of a broader range of products and services being sold at the market. The lack of risk diversification also makes small businesses more prone to losses and thus to the danger of not being able to effectively deduct interest expenses. Moreover, lending to small firms could be less profitable in view of the fixed costs related to giving loans and the problems in obtaining information about lenders. ${ }^{191}$

As outlined in Section 4.1.4, however, SMEs as a whole do not necessarily have problems in obtaining debt capital. Banks have increasingly adapted to the challenges of lending to small businesses and the financing gap has at least been narrowed for debt financing. In addition, the challenges of lending to small businesses do not necessarily have to prevent debt financing altogether. Instead, they may merely increase the interest rates imposed on affected entities. ${ }^{192}$ The deductibility of interest payments would then rather benefit SMEs than it would hurt them. Hence, it appears that SMEs do not generally suffer from the debt bias in income taxation. It is rather a certain group of SMEs not being able to obtain debt financing and not being able to deduct interest payments due to a lack of positive taxable income. This group primarily includes start-ups and gazelles. Their success is often based on new ideas and technologies that are unsuitable to serve as collateral and they lack

\footnotetext{
${ }^{190}$ See IBFD (2015) pp. $47 \mathrm{ff}$.

${ }^{191}$ See Freel (2007) pp. 23 ff.; OECD (2006) pp. 34 ff.

${ }^{192}$ See OECD (2013b) pp. 22 ff.; OECD (2015) pp. $40 \mathrm{f}$.
} 
proven track records of their business models and abilities, which aggravates the obtainment of loans. ${ }^{193}$

Given that the majority of SMEs have sufficient access to debt financing as well as positive income to deduct interest payments from, it does not make sense to provide general tax incentives to SMEs as a compensation for the debt bias, e.g., in the form of special tax rates, special depreciation schemes or tax credits on certain kinds of investments. In fact, such incentives rather tend to benefit those businesses without negative income and without a shortage in available debt financing. The debt bias therefore does not constitute a justification of these kinds of incentives. Measures effectively addressing the debt bias need to embrace the problems arising from it and target affected firms more accurately.

A few incentives aim more specifically at alleviating financing-related issues. In Belgium, for example, an additional $0.5 \%$ of notional interest can be deducted from taxable income by small enterprises and in Portugal 5\% of initial capital contributions and capital increases can be deducted by SMEs. Obviously, both measures do not improve the access to debt financing but they make equity financing more attractive with regard to taxation and could indeed reduce the debt bias. It is questionable, though, in how far they really support the taxpayers being most affected, i.e., loss-making firms. In the absence of refunds, these enterprises do not benefit from additional deductions, especially if carry forwards are not allowed. In Hungary, the tax credit of $60 \%$ on interest payments even has an adverse effect as it extends the debt bias rather than reducing it. The taxation of debt financing becomes even more advantageous and therefore constitutes an even bigger disadvantage for taxpayers suffering from the debt bias. ${ }^{194}$

Shareholder-level incentives are another group of regimes that may positively affect SMEs heavily relying on equity financing. They limit the double taxation of proceeds derived from equity investments and thereby reduce the debt bias. Once again, however, the group of SMEs having the most problems in obtaining debt financing and in effectively deducting interest payments due to incurred losses may not benefit - at least as long as they still make losses. During this time, firms are unlikely to pay dividends and their shareholders may not be able to realize capital gains. Reduced shareholder taxation therefore does not provide immediate relief and only kicks in as the respective SMEs generate positive returns. At this

\footnotetext{
${ }^{193}$ See IES (2005) pp. 140 f.; Freel (2007) pp. 23 ff.; Kerr/Nanda (2015) pp. 446 ff.

${ }^{194}$ However, the regime may have its merits, if SMEs are put at a competitive disadvantage because of excessive interest rates on small business loans. These would be reduced effectively. See Section 4.1.4.
} 
time, affected businesses could probably obtain debt financing anyway and the debt bias would no longer put them at a competitive disadvantage.

Altogether, the debt bias does not constitute an adequate argument for providing SME tax incentives in their current form, especially if the incentives do not directly relate to the taxation of equity financing (either at the firm level or at the shareholder level). There is simply no clear link between firm size and the inability to acquire loans. If the discrimination against equity financing is indeed perceived to be a problem, policy-makers should rather directly tackle the problem instead of trying to alleviate one distortion (equity vs. debt) by introducing another (SME vs. large). The debt bias could, for example, be addressed by generally reduced shareholder taxation or by aligning the treatment of payments on debt and equity on the firm level. ${ }^{195}$

\subsubsection{Double Taxation of Corporate Profits}

In most EU countries, corporate income is taxed on the corporate level as soon as profits are incurred and on the shareholder level when profits are distributed or capital gains are realized upon the disposal of participations. ${ }^{196}$ In practice, the double taxation of corporate profits negatively affects the success of the SME sector in several ways. First, it may prevent business creation. If the overall level of taxation and the hurdle after-tax rate of return of newly founded businesses becomes too high, dependent employment and alternative capital market investments could be more attractive and prevent businesses from being started. ${ }^{197}$ Employment income and alternative capital market investments, however, are also subject to taxes that are not necessarily lower. ${ }^{198}$ In fact, most of the tax systems in the EU and other developed countries do not feature full double taxation of corporate profits. Mostly, shareholder relief systems or imputation systems reduce tax wedges between the overall tax rate on corporate profits and the top PIT rate to a minimum or even create an advantage for

\footnotetext{
${ }^{195}$ Generally, there are two approaches to addressing the difference in treatment of equity and debt on the firm level. Either the deduction of interest payments on the firm level is abolished (or limited) or (notional) allowances on equity capital are granted (as in Belgium, Italy and Portugal). However, both approaches bear some problems. Notional interest deductions on equity induce substantial losses in tax revenues as well as additional administrative efforts and tax planning opportunities for taxpayers. Restricting interest deductions on debt, on the other hand, tends to lead to more complexity and makes the general investment climate less attractive. See Klemm (2007) pp. 229 ff.; Schreiber/Overesch (2007) pp. 816 ff.; Finke/Heckemeyer/Spengel (2014) pp. 1 ff.; Vogel (2014) pp. 91 ff.

${ }^{196}$ See IBFD (2015) pp. $47 \mathrm{ff}$.

${ }^{197}$ See OECD (2009a) p. 87.

${ }^{198}$ See Table 9 for a comparison of top marginal rates in the personal and the corporate income tax (including dividend taxation). In fact, the average top PIT rate across all EU Member States is higher than the nominal tax rate on corporate income.
} 
corporate profits (see Table 9). ${ }^{199}$ In view of these relief mechanisms, it appears highly questionable if businesses not being started due to corporate double taxation should be founded in the first place. Most likely, a true entrepreneur would not be deterred from starting a business by a minor tax wedge, especially as the non-corporate form of business not being subject to double taxation is also available.

Besides the discouragement of business start-ups, double taxation may also slow down firms' growth as it prevents incorporation. ${ }^{200}$ In fact, the choice of legal form has been found to be impacted by tax considerations, most notably differences in nominal tax rates. ${ }^{201}$ The welfare losses induced by the distortion of legal form choice are unclear, though. If investment decisions were distorted by the choice of legal form and the acquisition of funds was prevented, double taxation could indeed prevent firms from growing. ${ }^{202}$ As mentioned above, the size of the tax wedges in most EU countries is not very big, though. Hence, it appears unlikely that enterprises with substantial growth aspirations would 1) really abstain from incorporation because of a minimal tax rate advantage and 2) have their growth aspirations halted by being non-corporate. And even if that was the case, an improved alignment of (generally applicable) corporate and non-corporate income tax rates would be the better response to the problem than the SME tax incentives discussed in Sections 2 and 3.

Lastly, double taxation could prevent SMEs' success because shareholder taxation increases the cost of equity capital. The increase is likely to be more pronounced for SMEs than for large enterprises as the shareholder clienteles of both groups differ. Large corporations usually have access to international financial markets where shareholder taxes are neglected. ${ }^{203}$ In contrast to that, SMEs are more reliant on domestic, small-scale investors for whom shareholder taxation plays a significant role. As a result, SMEs incur higher cost of capital that - even if exclusively stemming from taxation - constitute a competitive disadvantage and could cause SMEs to be pushed out of the market. ${ }^{204}$

\footnotetext{
${ }^{199}$ As personal rates are mostly progressive, the top marginal rates in Table 9 overestimate the nominal tax burden of unincorporated businesses in the majority of countries. The numbers should therefore be considered with caution and not be compared directly. Business owners, however, tend to be in the upper brackets of the progressive schedule so that the rates displayed in Table 9 should provide a reasonable idea of the options entrepreneurs face when choosing the legal form of their businesses. See Gravelle/Lowry (2012) p. 3.

${ }^{200}$ See OECD (2009a) pp. $87 \mathrm{f}$.

${ }^{201}$ See Gordon/MacKie-Mason (1994) pp. 279 ff.; MacKie-Mason/Gordon (1997) pp. 477 ff.; Goolsbee (1998) pp. 143 ff.; Goolsbee (2004) pp. 2283 ff.; de Mooij/Nicodème (2008) pp. 478 ff.; Liu (2014) pp. 387 ff.

${ }^{202}$ See Wagner (2006) pp. $101 \mathrm{ff}$.

${ }^{203}$ See Spengel (2003) p. 92; OECD (2010a) p. 126.

${ }^{204}$ See Spengel/Bergner (2015) pp. $20 \mathrm{ff}$. The actual size of the problem is unclear, though. On the one hand, higher cost of capital could be avoided by choosing non-corporate legal forms. This strategy, of course, hinges on the tax rates imposed on non-corporate business income as well as potential non-tax factors speaking against
} 
Table 9: Tax wedge for corporate and non-corporate business income in the EU (2015)

\begin{tabular}{|c|c|c|c|}
\hline Country & PIT rate (in \%) & CIT rate (in \%) & $\Delta$ (in $\%$-points $)$ \\
\hline Austria & 50.00 & 43.75 & 6.25 \\
\hline Belgium & 53.50 & 50.49 & 3,01 \\
\hline Bulgaria & 15.00 & 14.50 & 0.50 \\
\hline Croatia & 47.20 & 29.60 & 17,60 \\
\hline Cyprus & 38.50 & 12.50 & 26.00 \\
\hline Czech Rep. & 16.05 & 31.15 & -15.10 \\
\hline Denmark & 50.00 & 55.36 & -5.36 \\
\hline Estonia & 20.00 & 20.00 & 0.00 \\
\hline Finland & 50.25 & 42.44 & 7.81 \\
\hline France & 49.00 & 64.38 & -15.38 \\
\hline Germany & 47.79 & 48.59 & -0.80 \\
\hline Greece & 33.00 & 33.40 & -0.40 \\
\hline Hungary & 31.96 & 31.96 & 0.00 \\
\hline Ireland & 40.00 & 57.13 & -17.13 \\
\hline Italy & 48.52 & 46.35 & 2.17 \\
\hline Latvia & 23.00 & 23.50 & -0.50 \\
\hline Lithuania & 15.00 & 27.75 & -12.75 \\
\hline Luxembourg & 44.10 & 43.38 & 0.72 \\
\hline Malta & 35.00 & 35.00 & 0.00 \\
\hline Netherlands & 52.00 & 43.75 & 8.25 \\
\hline Poland & 32.00 & 34.39 & -2.39 \\
\hline Portugal & 56.50 & 49.24 & 7.26 \\
\hline Romania & 16.00 & 29.44 & -13.44 \\
\hline Slovakia & 25.00 & 22.00 & 3.00 \\
\hline Slovenia & 50.00 & 37.75 & 12.25 \\
\hline Spain & 45.00 & 44.92 & 0.08 \\
\hline Sweden & 54.86 & 45.40 & 9.46 \\
\hline UK & 45.00 & 44.45 & 0.55 \\
\hline Mean & 38.72 & 37.95 & 0.77 \\
\hline
\end{tabular}

Note: Data was retrieved from ibfd.org

However, SME tax incentives on the firm level again appear to be an inadequate remedy. Compensating for one distortion by adding another is unlikely to create better overall neutrality, especially if the taxpayers affected by the initial distortion are not targeted accurately. With regard to targeting, addressing the shareholder level directly is the superior approach. Shareholder-level incentives, though, introduce distortions and discriminate against non-qualifying investments in large enterprises as well. In particular, special investment allowances as in France and Ireland do not provide a level playing field but rather revert a

\footnotetext{
or in favor of the corporate form. On the other hand, the problem of increased cost of capital could be further aggravated as taxes on dividends and capital gains induce the so-called lock-in effect, which causes firms to not distribute profits and shareholders to abstain from selling their shares in order to avoid shareholder-level taxes. As a consequence, available capital for new and expanding firms becomes even more scarce and expensive. The lock-in effect, of course, primarily affects new ventures and high-growth firms whereas well-established SMEs with stable cash flows may rather benefit from investors hesitance to divest. See Dai/Maydew/Shackelford/Zhang (2008) pp. 709 ff.; OECD (2009a) p. 89; Gentry (2016) pp. 321 ff.
} 
likely SME discrimination into a large business discrimination. ${ }^{205}$ In addition, the commonly used explicit size criteria come along with the same problems as on the firm level: more complexity in the tax system and a potential discouragement of growth. ${ }^{206}$

Even for investor-level incentives, the adequacy of tax incentives in compensating SMEs for corporate double taxation therefore appears questionable. Instead, a general reduction of taxes on dividends and capital gains emerges as the superior approach. It would reduce the disadvantages incurred by SMEs due to double taxation while avoiding the problems of explicit size restrictions. In practice, of course, the loss of tax revenues (compared to measures restricted to SMEs) is a major concern. ${ }^{207}$ The concern could be alleviated by limiting reduced taxation to significant shareholdings, i.e., shareholdings accounting for a certain percentage of all outstanding shares of the respective company. Such a restriction would practically exclude shareholders of large enterprises while also achieving an improved focus on the shareholders who cannot avoid dividend and capital gains taxation because they make a living on the proceeds from their participations (mostly owner-managers of small firms). A differentiated treatment according to the holding quota is already implemented in several countries, which proves the practicability. In Germany, for example, a restriction of preferential treatment is easily achievable by increasing the part of exempt dividends and capital gains in the Teileinkünfteverfahren while holding everything else equal.

\subsubsection{Tax Planning Opportunities for Multinational Enterprises}

Large enterprises usually run multinational operations whereas SMEs mostly operate exclusively on the domestic market. ${ }^{208}$ Cross-border operations, of course, come along with tax advantages and usually offer opportunities for tax planning. The overall tax liability can be reduced significantly as income is shifted to low-tax jurisdictions, e.g., through transfer pricing, hybrid structures taking advantage of legal mismatches and tax haven finance affiliates. ${ }^{209}$ The exact amount of savings from such activities, of course, varies across countries and companies. Overall, anecdotal as well as empirical evidence indicate substantial reductions of tax payments, though, and the lack of opportunities for cross-border profit

\footnotetext{
${ }^{205}$ The allowances reduce the PIT base of the investors when shareholdings in eligible SMEs are acquired and thereby lower personal income tax payments.

${ }^{206}$ See Holtz-Eakin (1995) p. 393.

${ }^{207}$ See Reister/Spengel/Finke/Heckemeyer (2009) p. 1.

${ }^{208}$ In fact, the vast majority of all SMEs in the European Union (in particular micro and small enterprises) do not feature any international business activities. See European Commission (2014) pp. $81 \mathrm{ff}$.

${ }^{209}$ See Jacobs/Endres/Spengel (2015) pp. 885 ff.
} 
shifting could put SMEs at a structural competitive disadvantage that would not arise in the absence of taxation. ${ }^{210}$ Possibly, this warrants the use of SME tax incentives as a consolation.

Whether effective tax rates really decrease in firm size, however, is questionable. Empirical evidence on the subject has been ambiguous so far. ${ }^{211}$ Moreover, smaller entities also have opportunities for tax planning that do not play a role for most large enterprises. Small businesses, for example, can often choose their legal form in a tax-optimal way. ${ }^{212}$ The limited number of shareholders of most micro and small enterprises also enables controlling owners to optimize profit distributions according to their personal needs and preferences. In addition, profits can be extracted with the help of contracts between the company and the owners (e.g., employment contracts and shareholder loans). These contracts oftentimes serve the purpose of saving taxes and do not necessarily reflect the real economic value of the services provided to the firm. ${ }^{213}$ Besides tax avoidance, small business owners also engage in tax evasion more than any other group of taxpayers. Especially self-employment is used as a vehicle for tax evasion. ${ }^{214}$ In the UK, for example, SMEs account for about half of the overall tax gap and the amount of evaded taxes relative to the overall amount of the estimated tax liability is nearly twice as high as for large enterprises (3.1\% compared to $1.8 \%){ }^{215}$

Altogether it is thus not clear, if and how much SMEs are really disadvantaged with regard to tax planning (and tax evasion) opportunities. Even if they were, this would not represent an adequate justification of SME tax incentives as they are currently implemented, though. As previously discussed, it is highly unlikely that compensating for one tax-induced distortion by introducing another distortion in the tax system leads to a higher degree of overall efficiency - especially if the extent and the dynamics of the initial distortion are not exactly known. Moreover, imposing lower tax burdens on more mobile capital may simply be efficient. So there may not even be a need for compensation. And lastly, a look at actual SME tax incentives shows that micro enterprises benefit by far the most whereas small and even more so medium-sized entities are often not affected by the regimes or only to a limited degree. It is predominantly micro enterprises, however, who can engage in the

\footnotetext{
${ }^{210}$ See Huizinga/Laeven (2008) pp. 1164 ff.; Clausing (2009) pp. 703 ff.; Egger/Eggert/Winner (2010) pp. 99 ff.; Pinkernell (2013) pp. 180 ff.;

${ }^{211}$ See Mills/Erickson/Maydew (1998) pp. 6 ff; Wilkinson/Cahan/Jones (2001) pp. 165 ff.; Gupta/Mills (2002) pp. 117; Richter/Samphantharak/Timmons (2009) pp. 898 ff.; Belz/von Hagen/Steffens (2016) pp. 2 ff.

${ }^{212}$ See Gordon/MacKie-Mason (1994) pp. 279 ff.; MacKie-Mason/Gordon (1997) pp. 477 ff.; Goolsbee (1998) pp. 143 ff.; Goolsbee (2004) pp. 2283 ff.; Luna/Murray (2010) pp. 995 ff.; Liu (2014) pp. 387 ff.; Jacobs/Scheffler/ Spengel (2015) p. 6.

${ }^{213}$ See Jacobs/Scheffler/Spengel (2015) pp. $569 \mathrm{ff}$.

${ }^{214}$ See Pissarides/Weber (1989) pp. 17 ff.; Feldman/Slemrod (2007) pp. 327 ff.

${ }^{215}$ See HM Revenue \& Customs (2015) p. 19. Data for the U.S. suggests small business owner to account for an even larger share of the tax gap. See Gale/Brown (2013) p. 881; IRS (2016) pp. $11 \mathrm{ff}$.
} 
abovementioned tax planning and tax evasion strategies existing for narrowly held companies. Most of the currently available tax incentives would thus be badly targeted if they were intended to compensate for an imbalance in tax planning opportunities.

\subsubsection{Compliance Costs}

Paying taxes does not only represent a burden for businesses due to the actual tax payments but also because determining the tax liability as well as paying the taxes cause considerable compliance costs. Previous studies have estimated compliance costs to amount on taverage to up to $21 \%$ of turnover ${ }^{216}$ and $150 \%$ of taxable income for the very smallest businesses. $^{217}$ The majority of studies, however, report significantly lower compliance burdens between $0.2 \%$ and $15 \%$ of revenues. ${ }^{218}$ Compliance costs are incurred for acquiring external expertise (e.g., tax advisers), for acquiring required materials and for hiring employees who take care of tax-related obligations. ${ }^{219}$ Importantly, a substantial share of the compliance burden is made up of fixed and quasi-fixed costs. Hence, large enterprises benefit from economies of scale and learning effects stemming from the volume and the frequency of their operations and related tax obligations. ${ }^{220}$ As a consequence, the compliance burden (relative to turnover or total assets) decreases in firm size and micro and small enterprises are subject to a disproportionally high compliance burden. ${ }^{221}$ So the tax system indeed puts SMEs at a competitive disadvantage that would not exist in the absence of taxation.

But does this discrimination justify the use of SME tax incentives? In contrast to the abovementioned structural disadvantages, enhanced compliance costs are really driven by firm size (or rather the lack hereof). The amount of sales of an enterprise actually determines how well fixed costs can be forwarded to customers through prices so that firm size is not only a more or less accurate proxy of the firm characteristic which truly causes the disadvantage but the actual reason of the disadvantage. ${ }^{222}$ Tax incentives based on firm size are thus well targeted at the businesses being affected.

\footnotetext{
${ }^{216}$ See Colmar Brunton (2005) p. 99.

${ }^{217}$ See DeLuca/Stilmar/Guyton/Lee/O'Hare (2007) p. 175.

${ }^{218}$ For a comprehensive literature overview on the measurement of tax compliance costs, see Eichfelder (2010) pp. $55 \mathrm{ff}$.

${ }^{219}$ See Eichfelder (2010) pp. $20 \mathrm{ff}$.

${ }^{220}$ See Eichfelder (2010) p. 59 f.

${ }^{221}$ See Sandford/Godwin/Hardwick (1989) pp. $197 \quad$ ff.; $\quad$ Slemrod/Venkatesh $\quad$ (2002) pp. 40; DeLuca/Stilmar/Guyton/Lee/O'Hare (2007) pp. $174 \mathrm{ff}$.

${ }^{222}$ See Eichfelder (2010) p. 217.
} 
Among the different forms of relief, administrative simplifications should be the primary choice to address disproportionate compliance burdens. Requiring simplified tax accounts, less frequents tax returns and fewer tax payments - as it is common practice in most EU Member States - should actually decrease enterprises' compliance costs. Administrative reliefs for micro and small businesses are thus effective and efficient instruments in alleviating the compliance-related distortion introduced by the tax system. In addition, simplified procedures also relieve the tax administration and are likely to increase net tax revenues. The use of administrative simplifications for very small businesses therefore appears well-grounded and is likely to contribute to the overall efficiency of the tax system.

Caution needs to be exercised with regard to the generosity and the exact eligibility thresholds, though. Preferential treatment for small businesses naturally partitions taxpayers and violates the neutrality of the tax system. ${ }^{223}$ The relief provided needs to be carefully weighed against the size-related disadvantage under the ordinary compliance obligations. Otherwise a discrimination against micro and small businesses easily turns into a discrimination against larger entities - either because eligibility thresholds are chosen too high or because the relief provided is too beneficial. In particular, regimes may be overly generous if they strongly deviate from standard procedures. If income is determined presumptively, for example, or if special regimes replace several taxes, the determination and collection of taxes is not only simplified but actual tax payments are significantly altered. ${ }^{224}$ Taxpayers are then put at a substantial competitive advantage compared to ineligible competitors and may be strongly incentivized to not forfeit access to the special regimes by remaining small (or by reporting to be small). ${ }^{225}$ In addition, simplifications should be harmonized with non-tax regulations. Eligibility thresholds for simplified tax accounting, for example, need to consider financial accounting regulations. A simplified regime would be misplaced if local accounting standards required comprehensive double-entry and accrualsbased book-keeping from the respective businesses anyway.

\section{Conclusion}

SMEs account for the bulk of economic activity in the European Union and they are essential to Europe's economic development and prosperity. As a consequence, the need for

\footnotetext{
${ }^{223}$ See Keen (2013) p. 27.

${ }^{224}$ For corporate entities, this is the case in Hungary, Latvia, Portugal and Romania. For non-corporate businesses, even more Member States offer presumptive and strongly simplified regimes. See Thuronyi (1996) pp. 406 ff; Bergner/Heckemeyer (2016) pp. 5 ff.

${ }^{225}$ See Kleven (2016) pp. $435 \mathrm{ff}$.
} 
specific SME support, most notably in the form of tax incentives, is a popular credo among European policy-makers. Tax incentives for specific groups of taxpayers should be treated with caution, though. Above all, the tax system needs to be as fair, as simple and as neutral as possible. Distortions in the allocation of resources need to be held to a minimum. Naturally, discriminatory treatment of small and large firms is contradictory to these guiding principles and there must be valid reasons when privileging either group. If such reasons are given, the adequacy of tax incentives depends on their ability to properly address and alleviate the targeted problems as well as on the costs associated with their implementation. In order to ensure their efficiency and avoid unintended adverse effects, they must be designed in a simple, transparent and neutral way.

With regard to currently available regimes, SME tax incentives are common practice in the Member States of the European Union. Most notably, reduced income tax rates are regularly offered to micro and small businesses as well as to their owners. In addition, inputbased incentives such as special depreciation schemes, tax allowances and tax credits can be found in numerous tax codes. The latter are frequently limited to rather specific areas of application, e.g., to certain underprivileged regions or to certain kinds of investments. Given these restrictions in the scope of application, the vast majority of regimes in the European Union does not have a significant impact on the tax burden of most SMEs. Comparing the three classes of SMEs, micro companies receive by far the most generous benefits, whereas small and - even more so - medium-sized entities are rarely subject to substantial tax cuts. Besides reductions in tax payments, the very smallest enterprises also benefit from administrative reliefs throughout the European Union. The simplifications range from less frequent tax payments and returns over simplified accounting requirements up to special regimes building on alternative tax bases (e.g., turnover) or even lump-sum payments.

Given the multitude of available SME incentives, the question of their justification arises. In general, the market mechanism should be assumed to induce the best available allocation of resources unless frictions prevent the well-functioning of the market. If, however, market failure does indeed occur and results in underinvestment in the SME sector, policy-intervention could be warranted. With regard to small businesses, positive externalities in the form of job creation and innovation as well as asymmetric information between business insiders and outsiders are the most commonly cited market failures. The latter induces an insufficient provision of capital as investors are unwilling to invest when they cannot properly assess the associated risks. 
Existing evidence does generally not confirm that the SME sector as a whole is affected by the aforementioned market failures. Instead, it is only a very small group of young and dynamic firms who feature an above-average propensity to generate jobs and innovation and who are subject to increased problems of obtaining sufficient financing due to their heightened capital needs and the uncertainty associated to their business models. The majority of SMEs, however, are not (or not so much) affected by market frictions. Tax incentives relying on size as the main eligibility criterion are thus not targeted adequately. In addition, most of the currently available regimes tend to provide exactly those businesses with the most generous reliefs that are the least affected by market failure, i.e., the well-established and highly profitable enterprises. Start-ups and upcoming high-growth, high-risk firms, by contrast, can often not take full advantage as they regularly do not have the positive income required to benefit from preferential tax rates and input-based, non-refundable tax credits and allowances.

Disadvantages of smaller entities emanating from the tax system constitute another line of argumentation in favor of providing SME tax incentives. Most prominently, SMEs are assumed to be discriminated against because their compliance burden is disproportionally high. Given that compliance costs are largely made up of fixed and quasi-fixed costs, whose impact decreases in firm size, there is indeed a case to be made for SME incentives. Firm size actually is the characteristic causing the problem and it should thus be the characteristic to be referred to when targeting compensatory relief. Naturally, the relief itself should relate to the underlying friction, which implies the provision of administrative reliefs rather than other instruments aiming at the actual tax liability (e.g., special tax rates).

In addition, SMEs are assumed to be disadvantaged by the tax system because they do not have the tax planning opportunities of large entities, because they are more affected by the double taxation of corporate profits and restricted loss offsets and because they are more reliant on equity financing that is traditionally disadvantaged in modern income tax systems. These alleged tax-related discriminations, however, do not justify the use of SME incentives. Evidently, owners of small businesses evade more taxes than any other group of taxpayers by mingling private and business affairs. Moreover, they have substantial leeway to organize operations in tax-minimizing ways as well, e.g., by choosing their legal form adequately, by timing profit distributions according to their preferences or by setting up contract relations with their businesses. Moreover, the double taxation of corporate profits, the discrimination of equity and the restriction of loss offsets do not necessarily affect small businesses more than 
large entities; and even if they did, the obvious approach would be to address the issues directly instead of trying to alleviate one distortion by introducing a new one.

Altogether, the use of SME tax incentives is mostly inappropriate. Considering currently available regimes, the majority of incentives are ineffective in addressing the problems of the SME sector. The provisions are regularly not well designed and cause unnecessary complexity in the tax code as well as additional distortions to investment and financing decisions. European policy-makers should thus shift their focus from providing specific and mostly ineffective SME tax incentives to the removal of tax-related obstacles to the growth of businesses. 


\section{References}

Acs, Z. J./Audretsch, D. B. (1988a), Innovation and firm size in manufacturing, Technovation, Vol. 7 (3), pp. 197-210.

Acs, Z. J./Audretsch, D. B. (1988b), Innovation in Large and Small Firms: An Empirical Analysis, The American Economic Review, Vol. 78 (4), pp. 678-690.

Acs, Z. J./Audretsch, D. B. (1990), Innovation and small firms. Cambridge: MIT Press.

Acs, Z. J./Mueller, P. (2008), Employment effects of business dynamics: Mice, Gazelles and Elephants, Small Business Economics, Vol. 30 (1), pp. 85-100.

Adams, J. D. /Jaffe, A.B. (1996), Bounding the effects of R\&D: an investigation using matched establishment-firm data, RAND Journal of Economics, Vol. 27 (4), pp. 700721.

Akcigit, U. (2009), Firm Size, Innovation Dynamics and Growth, Working Paper, Massachusetts Institute of Technology.

Akerlof, G. A. (1970), The Market for "Lemons": Quality Uncertainty and the Market Mechanism, The Quarterly Journal of Economics, Vol. 84 (3), pp. 488-500.

Aldrich, H. E./Cliff, J. E. (2003), The pervasive effects of family on entrepreneurship: toward a family embeddedness perspective, Journal of Business Venturing, Vol. 18 (5), pp. 573-596.

Allen, E. J. (2012), The information content of the deferred tax valuation allowance: Evidence from venture capital backed IPO firms, Working Paper, University of Southern California.

Amirkhalkhali, S./Mukhopadhyay, A. (1993), The Influence of Size and R\&D on the Growth of Firms in the U.S., Eastern Economic Journal, Vol. 19 (2), pp. 223-233.

Anonymous (2011), Comments and Discussion of "What Do Small Businesses Do?", Brookings Papers on Economic Activity, 2011 (2), pp. 119-142.

Arginelli, P. (2015), Innovation through R\&D Tax Incentives: Some Ideas for a Fair and Transparent Tax Policy, World Tax Journal, Vol. 7 (1), pp. 3-71.

Armington, C./Odle M. (1982), Small Business? How Many Jobs?, The Brookings Review, Vol. 1 (2), pp. 14-17.

Armour, J./Cumming, D. (2006), The Legislative Road to Silicon Valley, Oxford Economic Papers, Vol. 58 (4), pp. 596-635.

Arrow, K. (1962), Economic Welfare and the Allocation of Resources for Invention, in: The Rate and Direction of Inventive Activity: Economic and Social Factors, pp. 609-626, Princeton: Princeton University Press.

Audretsch, D. B. /Elston, J. A. (1997), Financing the German Mittelstand, Small Business Economics, Vol. 9 (2), pp. 97-110.

Audretsch, D./Klomp, L./Santarelli, E./Thurik, A. (2004), Gibrat's Law: Are the Services Different?, Review of Industrial Organization, Vol. 24 (3), pp. 301-324.

Audretsch, D. B./Lehmann, E. E. (2004), Financing High-Tech Growth: The Role of Banks and Ventures Capitalists, Schmalenbach Business Review, Vol. 56 (4), pp. 340-357. 
Audretsch, D. B./Mahmood, T. (1994), Firm selection and industry evolution: the post-entry performance of new firms, Journal of Evolutionary Economics, Vol. 4 (3), pp. 243-260.

Audretsch, D./Santarelli, E./Vivarelli, M. (1999), Start-up size and industrial dynamics: some evidence from Italian manufacturing, International Journal of Industrial Organization, Vol. 17 (7), pp. 965-983.

Avi-Yonah, R. S. (2006), The Three Goals of Taxation, The Tax Law Review, Vol. 60 (Fall 2006), pp. 1-28.

Baghana, R./Mohnen, P. (2009), Effectiveness of R\&D tax incentives in small and large enterprises in Que'bec, Small Business Economics, Vol. 33 (1), pp. 91-107.

Ball, R./Shivakumar, L. (2005), Earnings quality in UK private firms: comparative loss recognition timeliness, Journal of Accounting and Economics, Vol. 39 (1), pp. 83-128.

Baldwin, J./Picot, G. (1995), Employment Generation by Small Producers in the Canadian Manufacturing Sector, Small Business Economics, Vol.7 (4), pp. 317-331.

Baldwin, W. L./Scott, J. T. (1987), Market Structure and Technological Change, Chur: Harwood Academic Publishers.

Baregheh, A./Rowley, J./Hemsworth, D. (2016), The effect of organizational size and age on position and paradigm innovation, Journal of Small Business and Enterprise Development, Vol. 23 (3), pp. 768-789.

Barnes, M./Haskel, J. (2002), Job Creation, Job Destruction and the Contribution of Small Businesses: Evidence for UK Manufacturing, Working Paper, Queen Mary University of London.

Baumol, W. J. (1990), Entrepreneurship: Productive, Unproductive, and Destructive, Journal of Political Economy, Vol. 98 (5), pp. 893-921.

Becchetti, L./Trovato, G. (2002), The Determinants of Growth for Small and Medium Sized Firms. The Role of the Availability of External Finance, Small Business Economics, Vol. 19 (4), pp. 291-306.

Belz, T./von Hagen, D./Steffens, C. (2016), Taxes and Firm Size: Political Cost or Political Power?, Working Paper, University of Mannheim.

Berger, A. N./Udell, G. F. (1998), The economics of small business finance: The roles of private equity and debt markets in the financial growth cycle, Journal of Banking \& Finance, Vol. 22 (1), pp. 613-678.

Berggren, B./Olofsson, C./Silver, L. (2000), Control Aversion and the Search for External Financing in Swedish SMEs, Small Business Economics, Vol. 15 (3), pp. 233-242.

Bergner, S. M./Heckemeyer, J. H. (2016), Simplified Tax Accounting and the Choice of Legal Form, European Accounting Review, http://www.tandfonline.com/doi/pdf/10.1080/ 09638180.2016.1264881?needAccess=true, retrieved on January 8, 2016.

Birch, D. (1981), Who creates jobs?, The Public Interest, Vol. 65 (Fall 1981), pp. 3-14.

Birch, D. (1987), Job creation in America: how our smallest companies put the most people to work, New York: The Free Press.

Birch, D./Medoff, J. (1994), Gazelles, in: Solomon, L. C./Levenson, A. R. (eds.), Labor Markets, Employment Policy, and Job Creation, pp. 159-167, Boulder: Westview Press. 
BIS (2015), Small Business Survey 2014: SME employers, Research Paper, Department for Business, Innovation \& Skills.

Blanchflower, D. G./Oswald, A. J. (1998), What makes an Entrepreneur?, Journal of Labour Economics, Vol. 16 (1), pp. 26-60.

Bleda, M./Morrison, K./Rigby, J. (2013), The role and importance of gazelles and other growth firms for innovation and competitiveness, in: Cox, D./Rigby, J. (eds.), Innovation policy challenges for the 21st century, pp. 110-134, New York: Routledge.

Blöchle, D./Schmidt, C. (2015), Neue Finanzierungsformen für Innovation und Wachstum Steuerliche Implikationen und Steueroptimierungsstrategien, Corporate Finance, 2015 (6), pp. 216-222.

Bolnick, B. (2004), Effectiveness and Economic Impact of Tax Incentives in the SADC Region, Report, Nathan-MSI Group.

Bottazzi, G./Dosi, G./Lippi, M./Pammolli, F./Riccaboni, M. (2001), Innovation and corporate growth in the evolution of the drug industry, International Journal of Industrial Organization, Vol. 19 (7), pp. 1161-1187.

Bound, J./Cummins, C./Griliches, Z./Hall, B. H./Jaffe, A. B. (1984), Who Does R\&D and Who Patents?, in: Griliches, Z. (ed.), $R \& D$, Patents, and Productivity, pp. 21-54, Chicago: University of Chicago Press.

Braunerhjelm, P. (2012), Innovation and Growth: A Technical or Entrepreneural Residual?, in: Andersson, M./Johansson, B./Karlsson, C./Lööf, H. (eds.), Innovation and Growth: From R\&D Strategies of Innovating Firms to Economy-wide Technological Change, pp. 286-316, Oxford: Oxford University Press.

Braunerhjelm, P. (2014), The Swedish Entrepreneurship Forum 1994-2014 - From Small Business Dynamics to Entrepreneurial Growth and Societal Prosperity, in: Braunerhjelm, P. (ed.), 20 Years of Entrepreneurship Research - From Small Business Dynamics to Entrepreneurial Growth and Societal Prosperity, pp. 7-20, Stockholm: Swedish Entrepreneurship Forum.

Bresnahan, T. F./Greenstein, S./Henderson, R. M. (2012), Schumpeterian Question and Diseconomies of Scope - Illustrations from the Histories of Microsoft and IBM, in: Lerner, J./Stern, S. (eds.), National Bureau of Economic Research Conference Report: The Rate and Direction of Inventive Activity Revisited, pp. 203-276, Chicago: University of Chicago Press.

Brown, J. R./Fazzari, S./Petersen, B. C. (2009), Financing Innovation and Growth: Cash Flow, External Equity, and the 1990s R\&D Boom, The Journal of Finance, Vol. 64 (1), pp. 151-185.

Brown, C./ Hamilton, J./Medoff, J. L. (1990), Employers large and small. Cambridge: Harvard University Press.

Broersma, L./Gautier, P. (1997), Job Creation and Job Destruction by Small Firms: An Empirical Investigation for the Dutch Manufacturing Sector, Small Business Economics, Vol. 9 (3), pp. 211-224.

Brush, C./Hisrich, R. D. (1999), Women-Owned Businesses: Why do They Matter? in: Acs, Z. (ed.), Are Small Firms Important? Their Role and Impact, pp. 111-127, Boston: Kluwer Academic.

Buckley, P./Dunning, J./Pearce, R. (1984), An Analysis of the Growth and Profitability of the World's Largest Firms 1972 to 1977, Kyklos, Vol. 37 (1), pp. 3-26. 
Bundesministerium für Wirtschaft und Energie (2014), German Mittelstand: Motor der deutschen

Wirtschaft, http://www.midasgruppe.de/uploads/media/German_Mittelstand_Motor_der_deutschen _Wirtschaft___BMWI.pdf, retrieved on October 25, 2016.

Buschhüter, M./Striegel, A. (2015), IFRS für kleine und mittelgroße Unternehmen, Wiesbaden: Springer Gabler.

Butler, C./Greene, R. D. (1999), "Don't Call Me Small”: The Contribution of Ethnic Enterprises to the Economic and Social Well-Being of America, in: Acs, Z. (ed.), Are Small Firms Important? Their Role and Impact, pp. 129-145, Boston: Kluwer Academic.

Cabral, L. (1995), Sunk Costs, Firm Size and Firm Growth, The Journal of Industrial Economics, Vol. 43 (2), pp. 161-172.

Camisón-Zornoza, C./Lapiedra-Alcami, R./Segarra-Ciprés, M./Boronat-Navarro, M. (2004), A meta-analysis of innovation and organizational size, Organization Studies, Vol. 25 (3), pp. 331-361.

Caruso, A. (2015), Statistics of U.S. Businesses - Employment and Payroll Summary: 2012 Economy-Wide Statistics

Briefs, https://www.census.gov/content/dam/Census/library/publications/2015/econ/g12susb.pdf, retrieved on June 5, 2016.

Cassar, G. (2004), The financing of business start-ups, Journal of Business Venturing, Vol. 19 (2), pp. 261-283.

Cassar, G./Ittner, C. D./Cavalluzzo, K. S. (2015), Alternative information sources and information asymmetry reduction: Evidence from small business debt, Journal of Accounting and Economics, Vol. 59 (2), pp. 242-263.

Castellacci, F./Lie, C. M. (2015), Do the effects of R\&D tax credits vary across industries? A meta-regression analysis, Research Policy, Vol. 44 (4), pp. 819-832.

Cefis, E./Ciccarelli, M./Orsenigo, L. (2007), Testing Gibrat's legacy: A Bayesian approach to study the growth of firms, Structural Change and Economic Dynamics, Vol. 18 (3), pp. $348-369$.

Chen, D./Lee, F. C./Mintz, J. (2002), Taxation, SMEs and Entrepreneurship, Working Paper, OECD.

Chen, D./Mintz, J. (2011), Small Business Taxation: Revamping Incentives to Encourage Growth, University of Calgary - School of Public Policy Research Papers, Vol. 4 (7), pp. $1-31$.

Chen, J./Lu, W. (2003), Panel unit root tests of firm size and its growth, Applied Economics Letters, Vol. 10 (6), pp. 343-345.

Chittenden, F./Hall, G./Hutchinson, P. (1996), Small Firm Growth, Access to Capital Markets and Financial Structure: Review of Issues and an Empirical Investigation, Small Business Economics, Vol. 8 (1), pp. 59-67.

Clark, C. (2008), The impact of entrepreneurs' oral 'pitch' presentation skills on business angels' initial screening investment decisions, Venture Capital, Vol. 10 (3), pp. 257279.

Clausing, K. A. (2009), Multinational Firm Tax Avoidance and Tax Policy, National Tax Journal, Vol. 62 (4), pp. 703-725. 
Cogan, J. (1993), The Irish Experience with Literature-based Innovation Output Indicators, in: Kleinknecht, A/Bain, D. (eds.), New Concepts in Innovation Output Measurement, pp. 113-137, London: Palgrave Macmillan.

Cohen, W. M./Levin, R. C./Mowery, D. C. (1987), Firm Size and R\&D Intensity: A reexamination, The Journal of Industrial Economics, Vol. 35 (4), pp. 543-565.

Colmar Brunton (2005), Measuring the tax compliance costs of small and medium-sized businesses - $\quad$ a benchmark survey, https://taxpolicy.ird.govt.nz/sites/default/files/news/2005-07-19-report-sme-compliancecosts.pdf, retrieved on September 10, 2016.

Comanor, W. S. (1967), Market Structure, Product Differentiation and Industrial Research, The Quarterly Journal of Economics, Vol. 81 (4), pp. 639-657.

Coombes, M. G./Storey, D. J./Watson, R./Wynarczyk, P. (1991), The Influence of Location upon Profitability and Employment Change in Small Companies, Urban Studies, Vol. 28 (5), pp. 723-734.

Cooper, A. C./Gimeno-Gascon, F. J./Woo, C. Y. (1994), Initial Human and Financial Capital as Predictors of New Venture Performance, Journal of Business Venturing, Vol. 9 (5), pp. 371-395.

Cooper, I./Franks, J. R. (1983), The Interaction of Financing and Investment Decisions When the Firm has Unused Tax Credits, The Journal of Finance, Vol. 38 (2), p. 571-583.

Cowling, M./Mitchell, P. (1997), The Evolution of UK Self-employment: A Study of Government Policy and the Role of the Macroeconomy, The Manchester School, Vol. 65 (4), pp. 427-442.

Crawford, C./Freedman, J. (2010), Small Business Taxation, in: Mirrlees, J. A./Adam, S./Besley, T./Blundell, R./Bond, S./Chote, R./Gammie, M./Johnson, P/Myles, G./Poterba, J. (eds.), Dimensions of Tax Design, pp. 1028-1099, Oxford: Oxford University Press.

Cressy, R. (1996), Are Business Startups Debt-Rationed?, The Economic Journal, Vol. 106 (438), pp. 1253-1270.

Cressy, R. (2002), Funding Gaps: A Symposium, The Economic Journal, Vol. 112 (477), pp. F1-F16.

Cressy, R. (2006), Why Do Most Firms Die Young?, Small Business Economics, Vol. 26 (2), pp. 103-116.

Cressy, R./Olofsson, C. (1997), European SME Financing: An Overview, Small Business Economics, Vol. 9 (2), pp. 87-96.

Cullen, J. B./Gordon, R. H. (2007), Taxes and entrepreneurial risk-taking: Theory and evidence for the U.S., Journal of Public Economics, Vol. 91 (7), pp. 1479-1505.

Dai, Z./Maydew, E./Shackelford, D. A./Zhang, H. H. (2008), Capital Gains Taxes and Asset Prices: Capitalization or Lock-in?, The Journal of Finance, Vol. 63 (2), pp. 709-742.

Damanpour, F. (1992), Organizational size and innovation, Organization Studies, Vol. 13 (3), pp. 375-402.

Da Rin, M./Nicodano, G./Sembenelli, A. (2006), Public policy and the creation of active venture capital markets, Journal of Public Economics, Vol. 90 (8), pp. 1699-723.

Dasgupta, P. /Stiglitz, J. E. (1980), Industrial Structure and the Nature of Innovative Activity, The Economic Journal, Vol. 90 (358), pp. 266-293. 
Davidsson, P./Lindmark, L./Olofsson, C. (1998), The Extent of Overestimation of Small Firm Job Creation - An Empirical Examination of the Regression Bias, Small Business Economics, Vol. 11 (1), pp. 87-100.

Davis, S./Haltiwanger, J./Schuh, S. (1996a), Small Business and Job Creation: Dissecting the Myth and Reassessing the Facts, Small Business Economics, Vol. 8 (4), pp. 297-315.

Davis, S./Haltiwanger, J./Schuh, S. (1996b), Job creation and destruction, Cambridge: MIT Press.

DeHaven, T. (2012), Corporate Welfare in the Federal Budget, Policy Analysis, Vol. 703 (July 2012), pp. 1-17.

De Kok, J./Vroonhof, P./Verhoeven, W./Timmermans, N./Kwaak, T./Snijders, J./Westhof, F. (2011), Do SMEs create more and better jobs?, Report, EIM Business \& Policy Research.

Del Monte, A./Papagni, E. (1996), R\&D and the growth of firms: empirical analysis of a panel of Italian firms, Research Policy, Vol. 32 (6), pp. 1003-1014.

DeLuca, D./Stilmar, S./Guyton, J./Lee, W./O'Hare, J. (2007), Aggregate Estimates of Small Business Taxpayer Compliance Burdens, in: The IRS Research Bulletin - Proceedings of the 2007 IRS Research Conference, pp. 147-184.

De Meza, D. (2002), Overlending?, The Economic Journal, Vol. 112 (477), pp. F17-F31.

De Mooij, R. A./Nicodème, G. (2008), Corporate Tax Policy and Incorporation in the EU, International Tax and Public Finance, Vol. 15 (4), pp. 478-498.

Derregia, M./Chittenden, F. (2007), The Role of Tax Incentives in SMEs' Capital and Research \& Development Decisions, Report, Centre for Business Performance.

De Rugy, V. (2005), Are Small Businesses The Engine Of Growth?, Working Paper, American Enterprise Institute.

De Wit, G./de Kok, J. (2014), Do small businesses create more jobs? New evidence for Europe, Small Business Economics, Vol. 42 (2), pp. 283-295.

Diamond, D. W./Verrecchia, R. E. (1981), Information Aggregation in a Noisy Rational Expectations Economy, Journal of Financial Economics, Vol. 9 (3), pp. 221-235.

Diamond, D. W. (1991), Monitoring and Reputation: The Choice between Bank Loans and Directly Placed Debt, Journal of Political Economy, Vol. 99 (4), pp. 689-721.

Diamond, P. A./Mirrlees, J. A. (1971a), Optimal Taxation and Public Production I: Production Efficiency, The American Economic Review, Vol. 61 (1), pp. 8-27.

Diamond, P. A./Mirrlees, J. A. (1971b), Optimal Taxation and Public Production II: Tax Rules, The American Economic Review, Vol. 61 (3), pp. 261-278.

Donati, C. (2016), Firm growth and liquidity constraints: evidence from the manufacturing and service sectors in Italy, Applied Economics, Vol. 48 (20), pp. 1881-1892.

Droucopoulos, V. (1982), International Big Business, 1957-77: A Sequel on the Relationship between Size and Growth, Journal of Economic Studies, Vol. 9 (3), pp. 3-19.

Duarte, F./Matias Gama, P./Esperanca, J. P. (2016), The Role of Collateral in th credit Acquisition Process: Evidence from SME Lending, Journal of Business Finance \& Accounting, Vol. 43 (5/6), pp. 693-728.

Dunne, P./Hughes, A. (1994), Age, Size, Growth and Survival: UK Companies in the 1980s, The Journal of Industrial Economics, Vol. 42 (2), pp. 115-140. 
Dunne, T./Roberts, M. J. (1991), The Duration of Employment Opportunities in U.S. Manufacturing, The Review of Economics and Statistics, Vol. 73 (2), pp. 216-227.

Dunne, T./Roberts, M. J./Samuelson, L. (1988), Patterns of Firm Entry and Exit in U.S. Manufacturing Industries, RAND Journal of Economics, Vol. 19 (4), pp. 495-515.

Dunne, T./Roberts, M. J./Samuelson, L. (1989), The Growth and Failure of U.S. Manufacturing Plants, The Quarterly Journal of Economics, Vol. 104 (4), pp. 671-698.

Dushi, I./Iams, H. M./ Lichtenstein, J. (2011), Assessment of Retirement Plan coverage by Firm Size, Using W-2 Tax Records, Social Security Bulletin, Vol. 71 (2), pp. 53-65.

Edwards, C. (2000), Entrepreneurs creating the new Economy, Report, Joint Economic Committee of the U.S. Congress (Office of the Chairman).

EFI (2012), Research, Innovation and Technological Performance in Germany - Report 2012, Berlin: Expertenkommission für Forschung und Entwicklung.

Egger, P./Eggert, W./Winner, H. (2010), Saving taxes through foreign plant ownership, Journal of International Economics, Vol. 81 (1), pp. 99-108.

Eichfelder, S. (2010), Folgekosten der Besteuerung aus entscheidungstheoretischer Perspektive, Nürnberg: Datev.

Ennew, C. T./Binks, M. R. (1995), The Provision of Finance to Small Businesses: Does the Banking Relationship Constrain Performance, The Journal of Entrepreneurial Finance, Vol. 4 (1) pp. 57-73.

Ericson, R./Pakes, A. (1995), Markov-Perfect Industry Dynamics: A Framework for Empirical Work, The Review of Economic Studies, Vol. 62 (1), pp. 53-82.

Erkal, N./Scotchmer, S. (2009), Scarcity of Ideas and R\&D options: Use It, Lose It or Bank It, Working Paper, National Bureau of Economic Research.

Ettredge, M./Johnstone, K./Stone, M./Wang, Q. (2011), The effects of firm size, corporate governance quality, and bad news on disclosure compliance, Review of Accounting Studies, Vol. 16 (4), pp. 866-889.

European Commission (1996), Commission Recommendation of 3 April 1996 concerning the definition of small and medium-sized enterprises (96/280/EC), Official Journal of the European Communities, 1996 (L 107), pp. 4-9.

European Commission (2003), Commission Recommendation of 6 May 2003 concerning the definition of micro, small and medium-sized enterprises (2003/361/EC), Official Journal of the European Union, 2003 (L 124), pp. 36-41.

European Commission (2004), Business Demography in Europe - Results for 10 Member States and Norway, Luxembourg: Office for Official Publication of the European Communities.

European Commission (2007a), Remuneration of Researchers in the Public and Private Sectors (Final Report), Luxembourg: Office of Official Publications of the European Communities.

European Commission (2007b), Simplified tax compliance procedures for SMEs (Final Report of the Expert Group), http://ec.europa.eu/enterprise/policies/sme/files/support_measures/ taxsimple/taxsimp_en.pdf, retrieved on May 23, 2014.

European Commission (2008), Communication from the Commission to the Council, the European Parliament, The European Economic and Social Committee and the 
Committee of the Regions: "Think Small First" - A "Small Business Act" for Europe, Brussels.

European Commission (2009), Handbook on Community State Aid Rules for SMEs, Brussels.

European Commission (2010a), Europe 2020 - A European strategy for smart, sustainable and inclusive growth, Brussels.

European Commission (2010b), Commission Staff Working Document - Lisbon Strategy evaluation document, Brussels.

European Commission (2013), Communication from the Commission to the Council, the European Parliament, The European Economic and Social Committee and the Committee of the Regions: Entrepreneurship 2020 Action Plan - Reigniting the entrepreneurial spirit in Europe, Brussels.

European Commission (2014), Competitiveness Report 2014 - Helping Firms Grow, Luxembourg: Publications Office of the European Union.

European Commission (2015a), Annual Report on European SMEs 2014/15 - SMEs start hiring again, Brussels.

European Commission (2015b), SME taxation in Europe - An empirical study of applied corporate income taxation for SMEs compared to large enterprises: Final Report, Brussels.

European Commission (2015c), User Guide to the SME Definition, Luxembourg: Publications Office of the European Union.

European Investment Bank (2015), SME Report 2014, Luxembourg: EIB Group.

Evans, D. (1987a), Tests of Alternative Theories of Firm Growth, Journal of Political Economy, Vol. 95 (4), pp. 657-674.

Evans, D. (1987b), The Relationship Between Firm Growth, Size, and Age: Estimates for 100 Manufacturing Industries, The Journal of Industrial Economics, Vol. 35 (4), pp. 567581.

Evans, D. S./Jovanovic, B. (1989), An Estimated Model of Entrepreneurial Choice under Liquidity Constraints, Journal of Political Economy, Vol. 97 (4) pp. 808-827.

Evans, D. S./Leighton, L. S. (1989), Some Empirical Aspects of Entrepreneurship, The American Economic Review, Vol. 79 (3), pp. 519-535.

Fariñas, J./Moreno L. (2000), Firms' Growth, Size and Age: A Nonparametric Approach, Review of Industrial Organization, Vol. 17 (3), pp. 249-265.

Fazzari, S./Hubbard, R. G./Petersen, B. C. (1988), Investment, Financing Decisions, and Tax Policy, The American Economic Review, Vol. 78 (2), pp. 200-205.

Feeney, L./Haines, G. H./Riding, A. L. (1999), Private investors' investment criteria: insights from qualitative data, Venture Capital, Vol. 1 (2), pp. 121-145.

Feldman, N. E./Slemrod, J. (2007), Estimating Tax Noncompliance with Evidence from Unaudited Tax Returns, The Economic Journal, Vol. 117 (518), pp. 327-352.

Fell, D. R./Hansen, E. N./Becker, B. W. (2003), Measuring innovativeness for the adoption of industrial products, Industrial Marketing Management, Vol. 32 (4), pp. 347-353.

Finke, K./Heckemeyer, J. H./Spengel, C. (2014), Assessing the Impact of Introducing an ACE Regime - A Behavioural Corporate Microsimulation Analysis for Germany, Discussion Paper, Centre for European Economic Research. 
Freel, M. S. (2005), Patterns of innovation and skills in small firms, Technovation, Vol. 25 (2), pp. 123-134.

Freel, M. S. (2007), Are Small Innovators Credit Rationed?, Small Business Economics, Vol. 28 (1), p. 23-35.

Fuest, C./Spengel, C./Finke, K./Heckemeyer, J. H./Nusser, H. (2013), Profit Shifting and "Aggressive" Tax Planning by Multinational Firms: Issues and Options for Reform, World Tax Journal, Vol. 5 (3), pp. 307-324.

Gaillard-Ladinska, E./Non, M./Straathof, B. (2015), More R\&D with tax incentives? A metaanalysis, Discussion Paper, CPB Netherlands Bureau for Economic Policy Analysis.

Galbraith, J. K. (1956), American Capitalism: The Concept of Countervailing Power, Boston: Houghton Mifflin.

Gale, W./Brown, S. (2013), Small Business, Innovation, and Tax Policy, National Tax Journal, Vol. 66 (4), pp. 871-892.

Gallagher, C./Daly, M./Thomason, J. (1991), The Growth of UK Companies and Their Contribution to Job Generation, Small Business Economics, Vol. 3 (4), pp. 269-286.

Geberth, G. (2016), RegE eines "Gesetzes zur Weiterentwicklung der steuerlichen Verlustverrechnung bei Körperschaften", Der Betrieb, 2016 (37), p. M5.

Gentry, W. M. (2016), Capital Gains Taxation and Entrepreneurship, Tax Law Review, Vol. 69 (Spring 2016), pp. 321-356.

Gentry, W. M./Hubbard, R. G. (2005), "Success Taxes," Entrepreneurial Entry, and Innovation, Innovation Policy and the Economy, Vol. 5 (1), pp. 87-108.

Geroski, P. A. (1995), What do we know about entry?, International Journal of Industrial Organization, Vol. 13 (4), pp. 421-440.

Gompers, P. A./Lerner, J. (1998), What Drives Venture Capital Fundraising?, Brookings Papers on Economic Activity: Microeconomics, 1998, pp. 149-204.

Gompers, P. A./Lerner, J. (2001), The Venture Capital Revolution, The Journal of Economic Perspectives, Vol. 15 (2), pp. 145-168.

Goolsbee, A. (1998), Taxes, organizational form, and the deadweight loss of the corporate income tax, Journal of Public Economics, Vol. 69 (1), pp. 143-152.

Goolsbee, A. (2004), The impact of the corporate income tax: evidence from state organizational form data, Journal of Public Economics, Vol. 88 (11), pp. 2283-2299.

Gordon, R. H./MacKie-Mason, J. K. (1994), The distortions to the choice of organizational form, Journal of Public Economics, Vol. 55 (2), pp. 279-306.

Gravelle, J./Lowry, S. (2012), Small Business and the Expiration of the 2001 Tax Rate Reductions: Economic Issues, Report, Congressional Research Service Washington D.C.

Guenther, G. (2004), Small Business Tax Benefits: Overview and Economic Analysis, Report, Congressional Research Service.

Guenther, G. (2009), Small Business Tax Benefits: Overview and Economic Rationale, Report, Congressional Research Service.

Gupta, S./Mills, L. F. (2002), Corporate multistate tax planning: benefits of multiple jurisdictions, Journal of Accounting and Economics, Vol. 33 (1), pp. 117-139. 
Haegeland, T./Møen, J. (2007), Input additionality in the Norwegian R\&D tax credit scheme, Report, Statistics Norway.

Hall, B. H. (1987), The Relationship Between Firm Size and Firm Growth in the U.S. Manufacturing Sector, The Journal of Industrial Economics, Vol. 35 (4), pp. 584-606.

Hall, B. H./Lerner, J. (2010), The Financing of R\&D and Innovation, in: Hall, B. H./Rosenberg, N. (eds.), Handbooks of the Economics of Innovation, Vol. 1, pp. 609639, Amsterdam: Elsevier.

Hall, G./Hutchinson, P./Michaelas, N. (2000), Industry Effects on the Determinants of Unquoted SMEs' Capital Structure, International Journal of the Economics of Business, Vol. 7 (3) pp. 297-312.

Haltiwanger, J./Jarmin, R./Miranda, J. (2013), Who Creates Jobs? Small versus Large versus Young, The Review of Economics and Statistics, Vol. 95 (2), pp. 347-361.

Hamberg, D. (1964), Size of Firm, Oligopoly, and Research: The Evidence, The Canadian Journal of Economics and Political Science, Vol. 30 (1), pp. 62-75.

Harhoff, D./Stahl, K./Woywode, M. (1998), Legal Form, Growth and Exit of West German Firms - Empirical Results for Manufacturing, Construction, Trade and Service Industries, The Journal of Industrial Economics, Vol. 46 (4), pp. 453-488.

Hart, P. E. (1962), The Size and Growth of Firms, The Journal of Industrial Economics, Vol. 29 (113), pp. 29-39.

Hart, P. E./Prais, S. J. (1956), The Analysis of Business Concentration: A Statistical Approach, Journal of the Royal Statistical Society, Vol. 119 (2), pp. 150-191.

Hausman, A. (2005), Innovativeness among small businesses: Theory and propositions for future research, Industrial Marketing Management, Vol. 34 (8), pp. 773-782.

Headd, B. (2010), An Analysis of Small Business and Jobs, Working Paper, Small Business Administration.

Headd, B./Kirchhoff, B. (2009), The Growth, Decline and Survival of Small Businesses: An Exploratory Study of Life Cycles, Journal of Small Business Management, Vol. 47 (4), pp. 531-550.

Her Majesty's Revenue \& Customs (2015), Measuring tax gaps 2015 edition: Tax gap estimates for 2013-14, London: Her Majesty's Stationery Office.

Heshmati, A. (2001), On the Growth of Micro and Small Firms: Evidence from Sweden, Small Business Economics, Vol. 17 (3), pp. 213-228.

Hoffmann, K./Parejo, M./Bessant, J./Perren, L. (1998), Small firms, R\&D, technology and innovation in the UK: a literature review, Technovation, Vol. 18 (1), pp. 39-55.

Hohti, S. (2000), Job Flows and Job Quality by Establishment Size in the Finnish Manufacturing Sector 1980-94, Small Business Economics, Vol. 15 (4), pp. 265-281.

Holmström, B./Tirole, J. (1993), Market Liquidity and Performance Monitoring, Journal of Political Economy, Vol. 101 (4), pp. 678-709.

Holtz-Eakin, D. (1995), Should Small Businesses Be Tax-Favored?, National Tax Journal, Vol. 48 (3), pp. 387-395.

Holtz-Eakin, D./Joulfaian, D./Rosen, H. S. (1994a), Sticking it out: Entrepreneurial Survival and Liquidity Constraints, Journal of Political Economy, Vol. 102 (1), pp. 53-75. 
Holtz-Eakin, D./Joulfaian, D./Rosen, H. S. (1994b), Entrepreneurial decisions and liquidity constraints, RAND Journal of Economics, Vol. 25 (2), pp. 334-347.

Hong, S./Oxley, L./McCann, P./Le, T. (2016), Why firm size matters: investigating the drivers of innovation and economic performance in New Zealand using the Business Operations Survey, Applied Economics, Vol. 48 (55), pp. 5379-5395.

Honold, D. (2015a), Wer trägt das Risiko der Finanzierung von Innovation und Wachstum?, Corporate Finance, Vol. 6 (3), p. 1.

Honold, D. (2015b), Neue Formen der Eigenkapitalfinanzierung für Innovation \& Wachstum - Strukturen, Risiko und Kapitalkosten, Corporate Finance, Vol. 6 (6), pp. 197-206.

Hope, O.-K./Thomas, W. B./Vyas, D. (2013), Financial Reporting Quality of U.S. Private and Public Firms, The Accounting Review, Vol. 88 (5), pp. 1715-1742.

Horowitz, I. (1962), Firm Size and Research Activity, Southern Economic Journal, Vol. 28 (3), pp. 298-301.

Howorth, C. A (2001), Small Firms' Demand for Finance: A Research Note, International Small Business Journal, Vol. 19 (4), pp. 78-86.

Hsu, D. H. (2004), What Do Entrepreneurs Pay for Venture Capital Affiliation?, The Journal of Finance, Vol. 59 (4), pp. 1805-1844.

Hughes, A. (1997), Finance for SMEs: A U.K. Perspective, Small Business Economics, Vol. 9 (2), pp. 151-166.

Huizinga, H./Laeven, L. (2008), International profit shifting within multinationals: A multicountry perspective, Journal of Public Economics, Vol. 92 (5), pp. 1164-1182.

Hurst, E. G./Pugsley, B. W. (2011), What Do Small Businesses Do?, Brookings Papers on Economic Activity, 2011 (2), pp. 73-118.

Hurst, E. G./Pugsley, B. W. (2015), Wealth, Tastes, and Entrepreneurial Choice, Working Paper, National Bureau of Economic Research.

Hutchinson, R. W. (1995), The Capital Structure and Investment Decisions of Small OwnerManaged Firm: Some Exploratory Issues, Small Business Economic, Vol. 7 (3), pp. 231-239.

Hymer, S./Pashigan P. (1962), Firm Size and Rate of Growth, Journal of Political Economy, Vol. 70 (6), pp. 556-569.

Hyytinen, A./Väänänen, L. (2006), Where Do Financial Constraints Originate from? An Empirical Analysis of Adverse Selection and Moral Hazard in Capital Markets, Small Business Economics, Vol. 27 (4/5), pp. 323-348.

IBFD (2015), European Tax Handbook 2015, Amsterdam: International Bureau of Fiscal Documentation.

IES (2005), Annual Survey of Small Businesses, Report, Institute for Employment Studies.

IFS (2008), The IFS Green Budget, London: The Institute for Fiscal Studies.

IRS (2016), Federal Tax Compliance Research: Tax Gap Estimates for Tax Years 20082010, Washington DC: IRS.

Jacob, M./Pasedag, A./Wagner, F. W. (2011), Werden niedrige Steuersätze in Osteuropa durch Verzicht auf Verlustverrechnung erkauft?, Perspektiven der Wirtschaftspolitik, Vol. 12 (1), pp. 72-91. 
Jacobs, O. H./Scheffler, W./Spengel, C. (2015), Unternehmensbesteuerung und Rechtsform, Vol. 5, München: Verlag C. H. Beck.

Johnson, P. (2004), Differences in Regional Firm Formation Rates: A Decomposition Analysis, Entrepreneurship Theory \& Practice, Vol. 28 (5), pp. 431-446.

Jovanovic, B. (1982), Selection and Evolution of Industry, Econometrica, Vol. 50 (3), pp. 649-670.

Kaiser Family Foundation and Health Research \& Educational Trust (2016), Employer Health Benefits - 2016 Summary of Findings, https://kaiserfamilyfoundation.files.wordpress. com/2016/09/employer-health-benefits-2016-summary-of-findings.pdf, retrieved on October 31, 2016.

Keen, M. (2013), Taxation and Development - again, in: Fuest, C./Zodrow, G. R. (eds.), Critical Issues in Taxation and Development, pp. 13-44, Cambridge: MIT Press.

Kerr, W. R./Nanda, R. (2015), Financing Innovation, The Annual Review of Financial Economics, 2015 (7), pp. 445-462.

Keuschnigg, C./Nielsen, S. B. (2003), Tax policy, venture capital, and entrepreneurship, Journal of Public Economics, Vol. 87 (1), pp. 175-203.

Keuschnigg, C./Nielsen, S. B. (2004), Start-ups, venture capitalists, and the capital gains tax, Journal of Public Economics, Vol. 88 (5), pp. 1011-1042.

KfW Research (2016), KfW-Innovationsbericht Mittelstand 2015, https://www.kfw.de/ PDF/Download-Center/Konzernthemen/Research/PDF-Dokumente-Innovationsbericht/ KfW-Innovationsbericht-Mittelstand-2015.pdf, retrieved on August 18, 2016.

Kirchhoff, B./Phillips, B. (1988), The Effect of Firm Formation and Growth on Job Creation in the United States, Journal of Business Venturing, Vol. 3 (4), pp. 261-272.

Kleinknecht, A./Reijen, J./Smits, W. (1993), Collecting Literature-based Innovation Output Indicators: The Experience in the Netherlands, in: Kleinknecht, A/Bain, D. (eds.), New Concepts in Innovation Output Measurement, pp. 42-84, London: Palgrave Macmillan.

Klemm, A. (2007), Allowances for Corporate Equity in Practice, CESifo Economic Studies, Vol. 53 (2), pp. 229-262.

Klemm, A. (2010), Causes, benefits and risks of tax incentives, International Tax and Public Finance, Vol. 17 (3), pp. 315-336.

Kleven, H. J. (2016), Bunching, Annual Review of Economics, Vol. 8 (2016), pp. 435-464.

Kock (2007), Innovativeness and Innovation Success - A Meta-Analysis, Journal of Business Economics, Vol. 2 (Special Issue January 2007), pp. 1-21.

Krengel, R. (2006), Mindestbesteuerung und Effizienz - Eine ökonomische Analyse der Mindestbesteuerung im deutschen und US-amerikanischen Körperschaftsteuerrecht, Wiesbaden: Deutscher Universitäts-Verlag.

Kumar, M. (1985), Growth, Acquisition Activity and Firm Size: Evidence from the United Kingdom, The Journal of Industrial Economics, Vol. 33 (3), pp. 327-338.

Laforet, S. (2008), Size, strategic and market orientation affects on innovation, Journal of Business Research, Vol. 61 (7), pp. 753-764.

Laforet, S. (2009), Effects of size, market and strategic orientation on innovation in non-hightech manufacturing SMEs, European Journal of Marketing, Vol. 43 (1/2), pp. 188-212. 
Laforet, S. (2013), Organizational innovation outcomes in SMEs: Effects of age, size, and sector, Journal of World Business, Vol. 48 (4), pp. 490-502.

Laforet, S./Tann, J. (2006), Innovative characteristics of small manufacturing firms, Journal of Small Business and Enterprise Development, Vol. 13 (3), pp. 363-380.

Lee, N. (2014), What holds back high-growth firms? Evidence from UK SMEs, Small Business Economics, Vol. 43 (1), pp. 183-195.

Lee, C.-Y./Sung, T. (2005), Schumpeter's legacy: A new perspective on the relationship between firm size and R\&D, Research Policy, Vol. 34 (6), pp. 914-931.

Lerner, J. (1999), The Government as Venture Capitalist: The Long-Run Impact of the SBIR Program, The Journal of Business, Vol. 72 (3), pp. 285-318.

Liu, L. (2014), Income Taxation and Business Incorporation: Evidence from the Early Twentieth Century, National Tax Journal, Vol. 67 (2), pp. 387-418.

Liu, S. D./Skerratt, L. (2014), Earnings quality across listed, medium-sized, and small companies in the UK, Working Paper, Brunel University London.

Liu, J./Tsou, M./Hammitt, J. (1999), Do small plants grow faster? Evidence from the Taiwan electronics industry, Economics Letters, Vol. 65, pp. 121-129.

Lotti, F. (2007), Firm dynamics in manufacturing and services: a broken mirror?, Industrial and Corporate Change, Vol. 16 (3), pp. 347-369.

Lotti, F./Satarelli, E./Vivarello, M. (2013), Does Gibrat's Law hold among young, small firms?, Journal of Evolutionary Economics, Vol. 13 (3), pp. 213-235.

Lucas, R. E. (1988), On the Mechanics of Economic Development, Journal of Monetary Economics, Vol. 22 (1), pp. 3-42.

Luna, L. \& Murray, M. N. (2010). The effects of state tax structure on business organizational form. National Tax Journal, Vol. 63 (4), pp. 995-1022.

MacKie-Mason, J. K./Gordon, R. H. (1997), How much do taxes discourage incorporation?, The Journal of Finance, Vol. 52 (2), pp. 477-505.

Manly, T. S./Thomas, D. W./Schulman, C. T. (2015), Tax Incentives for Economic Growth: Capital Investment or Research, in: Hasseldine, J./Luttman, S. (eds.), Advances in Taxation, Vol. 17, pp. 95-120, Bingley: Emerald Publishing.

Mansfield, E. (1962), Entry, Gibrat's Law, Innovation, and the Growth of Firms, The American Economic Review, Vol. 52 (5), pp. 1023-1051.

Mason, C. M./Harrison, R. (1996), Why 'Business Angels' Say No: A Case Study of Opportunities Rejected by an Informal Investor Syndicate, International Small Business Journal, Vol. 14 (2), pp. 35-51.

Mason, C. M./Harrison, R. T. (2002), Barriers to investment in the informal venture capital sector, Entrepreneurship \& Regional Development, Vol. 14 (3), pp. 271-287.

Mason, C. M./Kwok, J. (2010), Investment Readiness Programmes and Access to Finance: A Critical Review of Design Issues, Local Economy, Vol. 25 (4), pp. 269-292.

Mata, J./Portugal, P. (1994), Life Duration of New Firms, The Journal of Industrial Economics, Vol. 42 (3), pp. 227-245.

Mata, J./Portugal, P./Guimaraes, P. (1995), The survival of new plants: Start-up conditions and post-entry evolution, International Journal of Industrial Organization, Vol. 13 (4), pp. 459-481. 
Maula, M./Murray, G./Jääskeläinen, M. (2007), Public Financing of Young Innovative Companies in Finland, Policy Study, Ministry of Trade and Industry Publications (Finland).

Meisel, J. B./Lin, S. A. Y. (1983), The Impact of Market Structure on the Firm's Allocation of Resources to Research and Development, The Quarterly Review of Economics and Business, Vol. 23 (4), pp. 28-43.

Mills, L./Erickson, M. M./Maydew, E. L. (1998), Investments in tax planning, The Journal of the American Taxation Association, Vol. 20 (1), pp. 1-20.

Mohnen, A./Nasev, J. (2008), Beschäftigungswachstum kleiner und mittlerer Unternehmen empirische Ergebnisse für Deutschland, Betriebswirtschaftliche Forschung und Praxis, Vol. 60 (5), pp. 481-497.

Moore, I./Garnsey, E. (1993), Funding for innovation in small firms: The role of government, Research Policy, Vol. 22 (5), pp. 507-519.

Mowery, D. C. (1983), Industrial Research and Firm Size, Survival, and Growth in American Manufacturing, 1921-1946: An Assessment, Journal of Economic History, Vol. 43 (4), pp. 953-980.

Myers, S. C. (1984), The Capital Structure Puzzle, The Journal of Finance, Vol. 39 (3), pp. 574-592.

Myers, S. C./Majluf, N. S. (1984), Corporate Financing and Investment Decisions when Firms Have Information that Investors Do not Have, Journal of Financial Economics, Vol. 13 (2), pp. 187-221.

Nanda, R. (2010), Entrepreneurship and the Discipline of External Finance, Working Paper, Harvard Business School.

Nassar, I. A./Almasafir, M. K./Al-Mahrouq, M. H. (2013), The Validity of Gibrat's Law in Developed and Developing Countries (2008-2013): Comparison Based Assessment, Procedia - Social and Behavioral Sciences, 2014 (129), pp. 266-273.

NESTA (2009), The vital 6 per cent - How high-growth innovative businesses generate prosperity and jobs, http://www.nesta.org.uk/publications/vital-6, March 2, 2016.

Neumark, D./Wall, B./Zhang, J. (2011), Do Small Businesses Create More Jobs? New Evidence for the United States from the National Establishment Time Series, The Review of Economics and Statistics, Vol. 93 (1), pp. 16-29.

Niemann, R. (2004), Investitionswirkungen steuerlicher Verlustvortrage -Wie schädlich ist die Mindestbesteuerung?, Zeitschrift für Betriebswirtschaft, Vol. 74 (4), pp. 359-384.

Niemann, R./Bachmann, M./Knirsch, D. (2003), Was leisten die Effektivsteuersätze des European Tax Analyzer?, Die Betriebswirtschaft, Vol. 63 (2), pp. 123-137.

Nooteboom, B. (1994), Innovation and Diffusion in Small Firms: Theory and Evidence, Small Business Economics, Vol. 6 (5), pp. 327-347.

North, D./Baldock, R./Ullah, F. (2013), Funding the growth of UK technology-based small firms since the financial crash: are there breakages in the finance escalator?, Venture Capital, Vol. 15 (3), pp. 237-260.

Oakey, R. (2007), A Commentary on Gaps in Funding for Moderate 'Non-Stellar' Growth Small Businesses in the United Kingdom, Venture Capital, Vol. 9 (3), pp. 223-235.

OECD (2001a), OECD Tax Policy Studies - Corporate Tax Incentives for Foreign Direct Investment, Paris: OECD Publications Service. 
OECD (2001b), Science, Technology and Industry Outlook - Drivers of Growth: Information Technology, Innovation and Entrepreneurship, Paris: OECD Publications Service.

OECD (2006), The SME Financing Gap - Theory and Evidence, Vol. 1, Paris: OECD Publishing.

OECD (2009a), OECD Tax Policy Studies - Taxation of SMEs - Key Issues and Policy Considerations, Paris: OECD Publishing.

OECD (2009b), Innovations in Firms - A Microeconomic Perspective, Paris: OECD Publishing.

OECD (2010a), Tax Policy Reform and Economic Growth, Paris: OECD Publishing.

OECD (2010b), Discussion Paper on Investment Readiness Programmes, Paris: OECD Publishing.

OECD (2013a), Action Plan on Base Erosion and Profit Shifting, Paris: OECD Publishing.

OECD (2013b), Financing SMEs and Entrepreneurs 2013: An OECD Scoreboard, Paris: OECD Publishing.

OECD (2014), Financing SMEs and Entrepreneurs 2014: An OECD Scoreboard, Paris: OECD Publishing.

OECD (2015), Financing SMEs and Entrepreneurs 2015: An OECD Scoreboard, Paris: OECD Publishing.

Omer, T.C./Plesko, G. A./Shelley, M. K. (2000), The influence of Tax costs on organizational choice in the natural resource industry, The Journal of the American Taxation Association, Vol. 22 (1), pp. 38-55.

Onji, K. (2009), The response of firms to eligibility thresholds: Evidence from the Japanese value-added tax, Journal of Public Economics, Vol. 93 (5/6), pp. 766-775.

Papke L. E./Wooldridge, J. M. (1996), Econometric methods for fractional response variables with an application to 401(K) plan participation rates, Journal of Applied Econometrics, Vol. 11 (6), pp. 619-632.

Papke L. E./Wooldridge, J. M. (2008), Panel data methods for fractional response variables with an application to test pass rates, Journal of Econometrics, Vol. 145 (1/2), pp. 121133.

Park, S. (2011), R\&D Intensity and Firm Size Revisited, Working Paper, University of California Los Angeles.

Pashev, K. V. (2006), Presumptive Taxation: Lessons from Bulgaria, Post-Communist Economies, Vol. 18 (4), pp. 399-418.

Pavitt, K./Robson, M./Townsend, J. (1987), The Size Distribution of Innovating Firms in the UK: 1945-1983, The Journal of Industrial Economics, Vol. 35 (3), pp. 297-316.

Petersen, M. A./Rajan, R. G. (1992), The Benefits of Lending Relationships: Evidence from Small Business Data, The Journal of Finance, Vol. 49 (1), pp. 3-37.

Piergiovanni, R./Santarelli, E. (2006), What is the Best Policy for Innovative Entrepreneurship?, in: Santarelli, E. (ed.), Entrepreneurship, Growth, and Innovation The Dynamics of Firms and Industries, pp. 261-274, New York: Springer.

Pinkernell, R. (2013), Das Steueroasen-Dilemma der amerikanischen IT-Konzerne, Internationales Steuerrecht, Vol. 22 (5), pp. 180-187. 
Pissarides, C. A./Weber, G. (1989), An Expenditure-Based Estimate of Britain's Black Economy, Journal of Public Economics, Vol. 39 (1), pp. 17-32.

Quadrini, V. (1999), The Importance of Entrepreneurship for Wealth Concentration and Mobility, Review of Income and Wealth, Vol. 45 (1), pp. 1-19.

Qureshi, A. (2013), Does Corporate Tax Lobbying Affect a Firm's Tax Rate?, Working Paper, University of Maryland.

Reinganum, J. F. (1985), A Two-Stage Model of Research and Development with Endogenous Second-Mover Advantages, International Journal of Industrial Organization, Vol. 3 (3), pp. 275-292.

Reister, T./Spengel, C./Finke, K./Heckemeyer, J. H. (2009), ZEW Corporate Taxation Microsimulation Model (ZEW TaxCoMM), Discussion Paper, Centre for European Economic Research.

Revest, V./Sapio, A. (2012), Financing technology-based small firms in Europe: what do we know?, Small Business Economics, Vol. 39 (1), pp. 179-205.

Richter, B. K./Samphantharak, K./Timmons, J. F. (2009), Lobbying and Taxes, American Journal of Political Science, Vol. 53 (4), pp. 893-909.

Robb, A. M./Robinson, D. T. (2014), The Capital Structure Decisions of New Firms, The Review of Financial Studies, Vol. 27 (1), pp. 153-179.

Romer, P. M. (1986), Increasing Returns and Long-Run Growth, Journal of Political Economy, Vol. 94 (5), pp. 1002-1037.

Romer, P. M. (1990), Endogenous Technological Change, Journal of Political Economy, Vol. 98 (5), pp. 71-102.

Samuels, J. (1965), Size and the Growth of Firms, Review of Economic Studies, Vol. 32 (2), pp. $105-112$.

Sandford C. T./Godwin, M./Hardwick, P. (1989), Administrative and Compliance Costs of Taxation, Bath: Fiscal Publications.

Santarelli, E./Piergiovanni, R. (1996), Analyzing literature-based innovation output indicators: The Italian experience, Research Policy, Vol. 25 (5), pp. 689-711.

Santarelli, E./Vivarelli, M. (2002), Is Subsidizing Entry an Optimal Policy?, Industrial and Corporate Change, Vol. 11 (1), pp. 39-52.

Scherer, F. M. (1965), Government Research and Development Programs, in: Dorfman, R. (ed.), Measuring Benefits of Government Investments, pp. 12-57, Washington D.C.: Brookings Institution.

Scherer, F. M. (1980), Industrial Market Structure and Economic Performance, Vol. 2, Chicago: Rand McNally College Publishing Company.

Schreiber, U./Overesch, M. (2007), Reform der Unternehmensbesteuerung, Der Betrieb, 2007 (15), pp. 813-820.

Schultz, C./Salomo, S./Talke, K. (2013), Measuring New Product Portfolio Innovativeness: How Differences in Scale Width and Evaluator Perspectives Affect its Relationship with Performance, Journal of Product Innovation Management, Vol. 30 (1), p. 93-109.

Schumpeter, J. A. (2010), Capitalism, Socialism, and Democracy. New York: Routledge.

Shane, S. (2009), Why encouraging more people to become entrepreneurs is bad public policy, Small Business Economics, Vol. 33 (2), pp. 141-149. 
Shefer, D./Frenkel, A. (2005), R\&D, firm size and innovation: an empirical analysis, Technovation, Vol. 25 (1), pp. 25-32.

Simon, H. A./Bonini, A. (1958), The Size Distribution of Business Firms, The American Economic Review, Vol. 48 (4), pp. 607-617.

Singh, A./Whittington, G. (1975), The Size and Growth of Firms, Review of Economic Studies, Vol. 42 (1), pp. 15-25.

Slemrod, J. (2013), Buenas notches: lines and notches in tax system design, eJournal of Tax Research, Vol. 11 (3), pp. 259-283.

Slemrod, J. B./Venkatesh, V. (2002), The income tax compliance cost of large and mid-size businesses, Report to the IRS, University of Michigan.

Solow, R. M. (1956), A Contribution to the Theory of Economic Growth, The Quarterly Journal of Economics, Vol. 70 (1), pp. 65-94.

Spengel, C. (2003), Internationale Unternehmensbesteuerung in der Europäischen Union: Steuerwirkungsanalyse - Empirische Befunde - Reformüberlegungen, Düsseldorf: IDW Verlag.

Spengel, C. (2016), IP-Box-Regime und steuerliche Förderung von Forschung und Entwicklung - passt das zusammen, in: Lüdicke, J./Schnitger, A./Spengel, C. (eds.), Besteuerung Internationaler Unternehmen - Festschrift für Dieter Endres zum 60. Geburtstag, pp. 409-423, München: Verlag C.H. Beck.

Spengel, C./Bergner, S. (2016), Investitionswirkungen der deutschen Unternehmensbesteuerung im internationalen Vergleich: eine Analyse vor dem Hintergrund der Steuerreformen 2001 und 2008 unter Berücksichtigung grenzüberschreitender Investitionen, Working Paper, University of Mannheim.

Spengel, C./Müller-Rees, V./Endres, D./Harhoff, D./Heinemann, F. /Hellwig, M./Hüther, M./ Regierer, C./Schön, W./Stein, K. (2009), Steuerliche Förderung von Forschung und Entwicklung $(F \& E)$ in Deutschland - Ökonomische Begründung, Handlungsbedarf und Reformbedarf, Heidelberg: Springer.

Stiglitz, J. E./Weiss, A. (1981), Credit Rationing in Markets with Imperfect Information, The American Economic Review, Vol. 71 (3), pp. 393-410.

Stiglitz, J. E./Weiss, A. (1992), Asymmetric Information in Credit Markets and Its Implications for Macro-Economics, Oxford Economic Papers, Vol. 44 (4), pp. 694-724.

Stiglitz, J. E. (2015), Leaders and Followers: Perspectives on the Nordic model and the economics of innovation, Journal of Public Economics, Vol. 127 (July 2015), pp. 3-16.

Stock, G. N./Greis, N. P./Fischer, W. A. (2002), Firm size and dynamic technological innovation, Technovation, Vol. 22 (9), pp. 537-549.

Stucki, T. (2013), Success of start-up firms: the role of financial constraints, Industrial and Corporate Change, Vol. 23 (1), pp. 1-40.

Symeonidis, G. (1996), Innovation, Firm Size and Market Structure: Schumpeterian Hypotheses and Some New Themes, Working Paper, OECD.

SZ (2016), Familienunternehmen gewinnen Lobbyschlacht um die Erbschaftsteuerreform, http://www.sueddeutsche.de/wirtschaft/erbschaftsteuer-familienunternehmen-gewinnendie-lobbyschlacht-1.3042505, retrieved on November 28, 2016.

Tang, A. (2015), Does Gibrat's law hold for Swedish energy firms?, Empirical Economics, Vol. 49 (2), pp. 659-674. 
taz (2016), Debatte Erbschaftsteuer für Firmenerben - Ein Lehrstück des Lobbyismus, http://www.taz.de/Debatte-Erbschaftsteuer-fuer-Firmenerben/!5231172/, retrieved on November 28, 2016.

Tether, B. S. (1998), Small and large firms: sources of unequal innovations?, Research Policy, Vol. 27 (7), pp. 725-745.

The Guardian (2014), Small businesses are the backbone of our communities, http://www. theguardian.com/small-business-network/2014/dec/06/small-businesses-backbonecommunities-john-longworth, retrieved on August 15, 2016.

The White House (2010), Small Businesses Are the Backbone of Our Economy and the Cornerstones of Our Communities, https://www.whitehouse.gov/blog/2010/08/17/small-businesses-are-backbone-oureconomy-and-cornerstones-our-communities, retrieved on August 15, 2016.

Thuronyi, V. (1996), Presumptive Taxation, in: Thuronyi, V. (ed.), Tax Law Design and Drafting, pp. 401-433, Washington D.C.: International Monetary Fund.

Toninelli, P. A./Vasta, M. (2010), Italian Entrepreneurship, in: Garcia-Lopey, J. L./Toninelli, P. A. (eds.), The Determinants of Entrepreneurship: Leadership, Culture, Institutions, pp. 49-79, London: Pickering and Chatto.

Trigo, A. (2013), The Nature of Innovation in R\&D- and Non-R\&D-intensive Service Firms: Evidence from Firm-level Latent Class Analysis, Industry and Innovation, Vol. 20 (1), pp. $48-68$.

Tsai, K.-H. (2005), R\&D productivity and firm size: a nonlinear examination, Technovation, Vol. 25 (7), pp. 795-803.

Tsai, K.-H./Wang, J.-C. (2005), Does R\&D performance decline with firm size? - A reexamination in terms of elasticity, Research Policy, Vol. 34 (6), pp. 966-976.

TSO (2009), The Provision of Growth Capital to UK Small and Medium Sized Enterprises, London: TSO.

Tucker, J./Lean, J. (2003), Small firm finance and public policy, Journal of Small Business and Enterprise Development, Vol. 10 (1), pp. 50-61.

Tysiac, K. (2012), Small Business, Big Risk - Fraud controls lacking at organizations with fewer than 100 employees, Journal of Accountancy, Vol. 214 (2), pp. 38-43.

Van Auken, H. E. (2001), Financing Small Technology-Based Companies: The Relationship between Familiarity with Capital and Ability to Price and Negotiate Investment, Journal of Small Business Management, Vol. 39 (3), pp. 240-258.

Variyam, J./Kraybill, D. (1992), Empirical evidence on determinants of firm growth, Economic Letters, Vol. 38 (1), pp. 31-36.

Verworn, B./Lüthje, C./Herstatt, C. (2000), Innovationsmanagement in kleinen und mittleren Unternehmen, Hamburg: TUHH.

Vogel, R. C./Adams, D. W. (1997), The Benefits and Costs of Loan Guarantee Programs, The Financier, Vol. 4 (1), pp. 22-29.

Vogel, T. (2014), Die Einflussnahme steuerlicher Lenkungsnormen auf Entscheidungen von Wirtschaftssubjekten, Lohmar: EUL Verlag.

Voulgaris, F./Papadogonas, T./Agiomirgianakis, G. (2005), Job Creation and Job Destruction in Greek Manufacturing, Review of Development Economics, Vol. 9 (2), pp. 289-301. 
Wagner, F. (2006), Was bedeutet und wozu dient Rechtsformneutralität der Unternehmensbesteuerung?, Steuer und Wirtschaft, 2006 (2), pp. 101-114.

Wakasugi, R./Koyata, F. (1997), R\&D, Firm Size and Innovation Outputs: Are Japanese Firms Efficient in Product Development?, Journal of Product Innovation Management, Vol. 14 (5), pp. 383-392.

Wallis, J./Dollery, B. (1999), Market Failure, Government Failure, Leadership and Public Policy, London: MacMillan Press.

Wilkinson, B. R./Cahan, S. F./Jones, G. (2001), Strategies and dividend imputation: the effect of foreign and domestic ownership on average effective tax rates, Journal of International Accounting, Auditing \& Taxation, Vol. 10 (2), pp. 157-175.

Winston, C. (2006), Government Failure versus Market Failure - Microeconomic Policy Research and Government Performance, Washington D.C.: Brookings Institution Press.

Wolfe, R. M. (2012), Business R\&D Performed in the United States Cost \$291 Billion in 2008 and \$282 Billion in 2009, Report, National Center for Science and Engineering Statistics.

Zee, H. H./Stotsky, J. G./Ley, E. (2002), Tax Incentives for Business Investment: A Primer for Policy Makers in Developing Countries, World Development, Vol. 30 (9), pp. 14971516.

Zimmermann, V. (2015), Innovationsfinanzierung - Herausforderung für mittelständische Unternehmen, Corporate Finance, 2015 (6), pp. 183-190.

Zimmermann, V./Andres, M. (2001), Das Innovationsverhalten von kleinen und mittleren Unternehmen, Wirtschaftsdienst, Vol. 81 (9), pp. 532-540. 


\section{Appendix}

\section{Annex 1: Country Reports}

In the following, available SME tax incentives and special regimes in the 28 countries of the European Union and selected other countries are described. Moreover, the country reports inform about other - generally applicable - provisions that might benefit or discriminate against SMEs. The focus of the summaries is on corporate income taxation. Transparently taxed enterprises, however, are subject to the majority of incentives, too (except for special CIT rates). ${ }^{226}$

The summaries also include special SME tax incentives for sole proprietors, partnerships and the shareholders of SMEs. Moreover, provisions targeted at newly founded enterprises are accounted for because most of them are either micro, small or medium-sized enterprises when starting their operations. Lastly, size-related reliefs in value-added taxation are considered. Although the final consumer is the subject of the value-added tax, reliefs do effectively benefit enterprises - in terms of compliance costs as well as actual tax payments. The terms micro, small and medium-sized enterprises are used in accordance with the standards given by the European Commission ${ }^{227}$ if not stated otherwise.

\section{Austria}

On the firm level, Austria does not offer special tax incentives for SMEs. There is only an adjusted minimum tax for newly founded companies of $€ 1,092$ that only benefits low-income companies. On the shareholder level, Austria grants full exemption to income from participations in unlisted European SMEs (i.e., dividends, capital gains and interest payments) for so-called intermediary investors. Intermediary investors must be corporate entities financed with equity capital. For individual investors, dividends from such intermediary investors are exempt from income taxation up to $€ 25,000$.

\footnotetext{
${ }^{226}$ If eligibility thresholds are reported in local currencies other than $€$, comparable euro amounts are given in brackets. Exchange rates as of December 31, 2015 were referred to for the conversion.

${ }^{227}$ The European Commission defines micro, small and medium-sized enterprises as businesses not exceeding certain thresholds for the number of employees (20/50/250), turnover ( $€ 2$ million/ $€ 10$ million/ $€ 50$ million) and total assets (€ 2 million/€ 10 million/€ 43 million). See Section 2.1 and European Commission (2003) p. 39.
} 
Enterprises are exempt from the value-added tax (VAT) if their turnover is lower than $€ 35,000$. Moreover, enterprises with less than $€ 100,000$ of turnover in the preceding year only have to file VAT returns and make VAT payments on a quarterly basis (instead of monthly). Suppliers with a turnover of less than $€ 110,000$ may pay VAT on a cash basis.

\section{Belgium}

Belgium has numerous incentives for SMEs in place. For tax purposes, an enterprise must meet the following criteria to be considered an SME:

- not more than 50 employees (and not more than 100 employees even if the other criteria are fulfilled);

- turnover does not exceed $€ 7$ million;

- balance sheet total does not exceed $€ 5$ million

- profits do not exceed $€ 322,500$.

Belgium offers several investment allowances. The general investment deduction for SMEs amounts to $10.5 \%$ of the depreciation taken on assets. The rate has varied between $10.5 \%$ and $12.5 \%$ since $2009 .{ }^{228}$ The incentive is restricted to companies with fewer than 20 employees. Unused amounts can be used in subsequent years with a maximum carry-forward of $€ 946,800$ (or $25 \%$ if the unused part exceeds $€ 3,787,210$ ). Additionally, an allowance of $20.5 \%$ is granted to SMEs for investments in safety measures either in the year of the investment or the following year. Concerning carry-forwards the same rules apply as for the above deductions. A notional interest deduction is available for all Belgian companies. It amounts to $4 \%$ of qualifying equity. ${ }^{229}$ SMEs, however, are allowed to deduct an additional $0.5 \%$. Since 2012 , carry-forwards are no longer possible.

With regard to depreciation, SMEs may - irrespective of the exact date of acquisition deduct $100 \%$ of the ordinary annual depreciation for an asset in the year of acquisition. ${ }^{230}$ Moreover, all costs related to the acquisition of depreciable assets can be immediately

\footnotetext{
228 The exact rates in this period are as follows: $10.5 \%$ from 2009 to $2011,12.5 \%$ in 2012 and $11.5 \%$ in 2011 .

229 The exact rates for large companies from 2009 to 2013 are as follows: $4.307 \%$ in 2009, 4.473\% in 2010, 3.8\% in 2011, 3.425\% in 2012 and $3 \%$ in 2013 . The respective rates for SME are $0.5 \%$ higher.

${ }^{230}$ Until 2010, the regime was more generous. SMEs could incur depreciations on all assets that were twice as high as the normal rate in the first three years of usage.
} 
depreciated. Newly founded companies can also immediately depreciate all costs of establishment.

SMEs may shift income into a tax-exempt reserve of at most $€ 37,500$ or $50 \%$ of retained earnings. The maximum size of the reserve can be further reduced by the following circumstances:

- occurrence of capital gains on shares that are eligible for participation exemption;

- occurrence of exempt capital gains on cars used for business purposes;

- occurrence of gains on debt claims against managers, shareholders and their spouses or children;

- paid-up capital is decreased.

The income entering the reserve needs to be re-invested within three years. The reserve must not be used in combination with the notional interest deduction on equity.

SMEs in Belgium also benefit from progressive corporate income tax rates (rates are given excluding the surcharge of $3 \%$ ):

- $24.25 \%$ on income $\leq € 25,000$;

- $31 \%$ on income between $€ 25,000$ and $€ 90,000$;

- $34.5 \%$ on income between $€ 90,000$ and $€ 322,500$;

- $33 \%$ on all income beyond that.

Certain types of companies are not allowed to apply the reduced rates (financial companies, collective investment companies, companies owned by other companies by $50 \%$ or more, companies whose distributions exceed $13 \%$ of paid-in capital, members of groups with a coordination center and companies not paying at least $€ 36,000$ to a director or active partner). The size of the tax credit on R\&D investments - if utilized - is adjusted to the progressive schedule.

Further reliefs for SMEs include exemptions from the special tax on capital gains $(0.412 \%)$ and the so-called "Fairness Tax". The latter is levied at 5.15\% (including austerity surcharge) upon distributions that are made in spite of losses or in the absence of taxable income due to other tax incentives. Moreover, $80 \%$ of SMEs' income derived from self-developed patents are tax exempt. Large firms only benefit from this exemption if the underlying patents were 
acquired. With regard to administrative regulations, SMEs do only have to make yearly tax payments (instead of quarterly).

On the shareholder level, dividend distributions from SMEs with respect to shares issued after July 1st 2013, are subject to reduced withholding taxes if they are made at least three years after issuance (20\% in the third year and $15 \%$ in the fourth and subsequent years instead of $25 \%)$. For this purpose, the following conditions need to be met:

- The shares must be held continuously and in full ownership by the same shareholder for three or four years.

- The shares must be issued in exchange for cash contributions.

- The statutory minimum amount of capital must be paid up.

Capital gains of SMEs from their subsidiaries are completely exempt from capital gains taxation if the subsidiaries meet certain qualitative criteria.

Lastly, there is an advance payment system in place for the taxation of liquidation proceeds from SMEs. Eligible SMEs may create a "liquidation reserve" from after-tax profits which must be maintained on a separate equity owner's account. The liquidation reserve immediately is subject to a separate non-deductible tax of $10 \%$. In return, no dividend withholding tax is due upon liquidation. If the liquidation reserve is distributed as a dividend within 5 years, though, a dividend withholding tax of $15 \%$ is due (5\% if distributed after more than 5 years).

Newly founded enterprises may immediately depreciate all costs of establishment and costs related to the creation of the enterprise.

With regard to the VAT, SMEs are exempt if their turnover does not exceed $€ 15,000$.

\section{Bulgaria}

Bulgaria does not have special tax incentives for SMEs. Small companies are subject to administrative reliefs, though. Enterprises whose net sales in the previous year were below BGR 300,000 $(\approx € 150,000)$ do not have to make advance tax payments and those with net sales below BGR 3,000,000 $(\approx € 1,500,000)$ only have to make quarterly advance payments (instead of monthly). In addition to that, simplified accounting standards apply for SMEs.

VAT registration is only required for enterprises with more than $€ 25,565$ of turnover. 


\section{Croatia}

Croatia provides comprehensive investment incentives for new undertakings. Income from new investments (also by existing enterprises) can be subject to corporate income tax rates that are reduced by up to $100 \%$ for 10 years. The exact amount of the reduction depends on the size of the investment and on the number of newly created jobs related to the investment:

- $100 \%$ reduction if investment of at least $€ 3$ million and related to 15 new employees;

- $75 \%$ reduction if investment of at least $€ 1$ million and related to 10 new employees;

- $50 \%$ reduction if investment of less than $€ 1$ million and related to 5 new employees.

For micro companies with up to 10 employees, a special regime exists that grants a $50 \%$ relief (resulting in a tax rate of $10 \%$ compared to the normal 20\%) if the investment amounts to at least $€ 50,000$ and creates 3 new jobs. Before the Law on Investment Promotion (2012), Croatia offered a similar incentive schedule without a special schedule for micro companies and with higher thresholds for eligibility:

- $100 \%$ reduction if investment of at least $€ 8$ million and related to 75 new employees (50 for R\&D activities);

- $80 \%$ reduction if investment of at least $€ 4$ million and related to 50 new employees (25 for R\&D activities);

- $65 \%$ reduction if investment of at least $€ 1.5$ million and related to 30 new employees (15 for R\&D activities);

- $50 \%$ reduction if investment of $€ 300,000$ ( $€ 100,000$ for $R \& D$ activities) to $€ 1$ million and related to 10 (5) new employees.

In addition, extensive reliefs were available for companies in economically weak regions. These regional incentives have been abolished. Croatia also provides a special allowance for eligible costs for general education and training (60\%) and special education and training (25\%) for employees. The percentages increase for medium-sized to $70 \%$ and $35 \%$, for small and micro enterprises to $80 \%$ and $45 \%$, respectively. 
VAT registration is only required if the turnover exceeds HRK 230,000 $(\approx € 30,000)$. Quarterly VAT payments (instead of monthly) can be made if the turnover is below HRK $800,000(\approx € 100,000)$.

\section{Cyprus}

There are no tax incentives for small and medium-sized enterprises in Cyprus.

\section{Czech Republic}

The Czech Republic provides comprehensive investment incentives for new undertakings. Income from new investments (also by existing enterprises) can be subject to full exemption from the corporate income tax for 10 years. The exemption applies if the following conditions are met:

- investment of at least CZK 100 million $(\approx € 3,7$ million) in the manufacturing sector;

- investment of at least CZK 10 million $(\approx € 370,000)$ and creation of at least 40 new jobs in so-called technological centers;

- creation of at least 40 new jobs in strategic service centers.

Businesses are exempt from the VAT if their turnover is below CZK 1 million $(\approx € 37,000)$.

\section{Denmark}

There are no tax incentives specifically targeted at SMEs in Denmark. With regard to administrative obligations, there is a relief from transfer pricing documentation for small companies with not more than 250 employees, a maximum turnover of DKK 250 million $(\approx € 33$ million) and a maximum balance sheet total of DKK 125 million ( $\approx € 17$ million). The relief only applies if no transactions with other entities outside the EEA are made. For VAT purposes, no registration is required if turnover is below DKK 50,000 $(\approx € 7,000)$. Half-yearly payments (instead of monthly) are allowed if taxable revenues are below DKK 5 million 
$(\approx € 670,000)$. Quarterly payments suffice if revenues do not exceed DKK 50 million $(\approx € 7,000)$.

\section{Estonia}

Estonia provides no special tax incentives for corporate SMEs. This is due to the Estonian tax system that does not tax corporate income as such but only corporate distributions. Consequently, there are no reliefs of corporate income at all.

Registration for VAT is only required if turnover exceeds $€ 16,000$.

\section{Finland}

Finland does not provide tax incentives specifically targeted at SMEs. There is a regime of accelerated depreciation for fixed assets being used in production activities (200\% of the usual depreciation rate on machinery, equipment and industrial buildings). The regime used to be restricted to SMEs until 2013 but is now available for all enterprises. Moreover, the super deduction of $100 \%$ of salary costs incurred for $R \& D$ projects is capped at $€ 400,000$. SME should therefore benefit more than large enterprises.

Businesses with less than $€ 8,500$ of turnover are exempt from VAT. If turnover is below $€ 25,000$, only yearly VAT payments need to be made, if it is below $€ 50,000$, only quarterly payments are required (instead of monthly). Moreover, SMEs are subject to reduced documentation requirements with regard to transfer prices.

\section{France}

France offers a multitude of tax incentives specifically designed for SMEs. The provisions include tax credits, special tax rates and various exemptions from income tax. Enterprises are generally considered SMEs if they comply with the SME criteria by the European Commission.

A special tax rate of $15 \%$ is available for SMEs with less than $€ 7,630,000$ of turnover. The SME must be held directly or indirectly by individuals or other SMEs fulfilling the aforementioned condition. The special corporate income tax rate applies to income up to $€ 38,120$ (instead of the usual rate of $33.33 \%$ ). The surcharge of $3.33 \%$ is dispensed for all SMEs meeting the turnover criterion, whereas all other enterprises incur the surcharge on 
income tax payments beyond the threshold of $€ 763,000$. Since 2012, another surcharge of $10.7 \%$ (5\% until 2012) is in place for all companies with an income of more than $€ 250$ million, which, by definition, does not apply to SMEs.

Furthermore, micro enterprises may use simplified rules to determine taxable income if two of the following three criteria are met:

- turnover $\leq € 534,000$;

- balance sheet total $\leq € 267,000$;

- number of employees $\leq 10$.

Micro enterprises with less than $€ 82,200$ (sale of goods) or $€ 32,900$ (services) of income, respectively, may even opt for lump-sum expense deductions from turnover to determine their taxable income ( $71 \%$ for sales activities; $50 \%$ for service activities; $34 \%$ for professional services).

France also offers several tax credits for SMEs. A credit of $20 \%$ is granted on expenditures related to innovative activities up to $€ 400,000$. Another credit is available for SMEs with at least 20 employees. The credit equals the difference of the income tax payable multiplied with a rate reflecting the size of the increase in employment and the corporate income tax paid effectively in the preceding year $(\rightarrow$ income tax payable * employment rate - income tax payable $\left._{\mathrm{t}-1}\right)$. The employment rate ranges from 0 to $100 \%$ with $100 \%$ reflecting an increase of $15 \%$ or more in personnel expenses compared to the preceding year. The credit only applies if the number of employees compared to each of the previous two years increased by at least $15 \%$. Until 2014, another one-off corporate tax credit was granted to SMEs for expenses related to the hiring of an employee to develop export activities outside the EU. The credit amounted to $50 \%$ of qualifying expenses and was limited to $€ 40,000$ over a two-year period. Lastly, there is a special tax credit for SMEs on the island of Corsica. The credit amounts to $20 \%$ and is granted on the following investments:

- depreciable assets that qualify for declining-balance method depreciation;

- the installation or arrangement of commercial premises;

- software necessary for the use of the aforementioned assets or premises;

- renovation of hotels. 
In order to be applicable, enterprises' turnover must not exceed $€ 40$ million, the number of employees must not exceed 250 and at least $75 \%$ of the shares need to be held by individuals or other SMEs. Unused credits can be carried forward for 9 years. A partial refund is available after 5 years (35\%; $50 \%$ after 9 years). New firms are granted an immediate refund.

A full exemption from the business tax (CAVE) applies to SMEs if their turnover is below $€ 152,500$. Due to allowances, businesses with a turnover below $€ 500,000$ are effectively exempt as well. Moreover, the allowance creates a progressive tax rate structure for the business tax:

- turnover between $€ 0$ and $€ 500,000: 0 \%$;

- turnover between $€ 500,000$ and $€ 3$ million: $0 \%$ to $0.5 \%$;

- turnover between $€ 3$ million and $€ 10$ million: $0.5 \%$ to $1.4 \%$;

- turnover between $€ 10$ million and $€ 50$ million: $1.4 \%$ to $1.5 \%$.

In addition, newly founded innovative SMEs are subject to an exemption from corporate income tax in the first two years of operations (100\% in the first year, $50 \%$ of income derived in the second year of their innovative activities). Eligible SMEs must not be older than eight years and pursue R\&D activities that account for at least $15 \%$ of the total expenses incurred. The incentive also includes exemption from the local business tax and social security contributions. Until 2011 SMEs were even granted five years of relief (three years with an exemption of $100 \%$ and two years with $50 \%$ ). Newly created companies may also benefit from tax exemptions in certain regions ("redevelopment areas") for the first five years of operations. The exemption decreases gradually from $100 \%$ to $75 \% / 50 \% / 25 \%$ in the last three years of the five-year period. The maximum relief that can be obtained from this incentive amounts to $€ 200,000$. The same limit applies to the exemption of income from SMEs that were created to take over companies in hardship. The regime is only available in certain regions and only in the first two years of operation of these newly founded SMEs. Another five-year exemption (100\%) is offered to newly created companies in tax-free urban zones. Enterprises need to have at least one employee in order to be eligible. The maximum exemption equals $€ 100,000$ per year and further tax incentives can be used under this regime.

Another exemption from income taxes exists for SMEs with regard to capital gains from the sale of a complete branch of activity excluding gains on immovable property. The exemption amounts to $100 \%$ if the value of the branch does not exceed $€ 300,000$ and to $50 \%$ if it is 
between $€ 300,000$ and $€ 500,000$. At least $75 \%$ of the disposing SME must be held directly or indirectly by individuals or other SMEs.

Further preferential treatments for SMEs include the following:

- SMEs are eligible for an immediate refund of the R\&D tax credit that is generally applicable for enterprises of all size classes. The R\&D tax credit at $30 \%$ is also capped as only expenses up to $€ 100$ million are eligible. Beyond the threshold the credit is reduced to 5\%, which can only affect large enterprises.

- SMEs are subject to beneficial provisions concerning the immediate recognition of losses from foreign branches. The offsetting enterprise must not have more than 2,000 employees, be subject to corporate income tax and be owned (75\%) by individuals or other enterprises fulfilling the above two conditions. Moreover, the source state must impose income taxes that are comparable to the French taxes and have an administrative assistance clause in the tax treaty with France. The maximum cash benefit from this regime must not exceed $€ 500,000$.

Shareholders of SMEs benefit from various other reliefs:

- Retiring SME owners are eligible for an allowance of $€ 500,000$ on the sale of their shares in the SME. Capital gains of directors of SMEs who sell their shares upon retirement are also exempt if certain requirements concerning the holding period are met.

- Capital gains from the disposal of shares in SMEs are (partly) exempt: 50\% if the holding period has been between 1 and 4 years, 65\% if from 4 to 8 years and $85 \%$ for holdings over 8 years. This relief only applies if the SME had not existed for more than 10 years at the time of acquisition, is subject to CIT and situated in an EEA country. Retiring owners of SMEs do not have to fulfill these conditions.

- $18 \%$ of amounts invested in qualifying SMEs can be deducted from the personal income tax base up to an amount of $€ 50,000$ (for small companies) or $€ 20,000$ (for medium-sized companies). 
- $50 \%$ of investments in qualifying SMEs are deductible for wealth tax purposes up to an amount of $€ 45,000$.

- Capital contributions to innovative SMEs can be depreciated over 5 years under certain conditions.

- Venture capital firms benefit from an exemption of their income from securities and shareholdings. Certain criteria with regard to the legal form and the assets of venture capital firms apply.

For purposes of the VAT, enterprises are exempt if their turnover does not exceed $€ 80,000$ (supply of goods/accommodation/food) or $€ 32,000$ (supply of other services). A simplified regime with quarterly provisional payments and a year-end final settlement is available for enterprises with less than $€ 763,000$ (supply of goods/accommodation/food) or $€ 230,000$ (supply of other services) of turnover.

\section{Germany}

Germany has two tax incentives in place that target specifically small companies. For both reliefs, the following criteria must be met in order to be eligible:

- Net assets must be smaller than $€ 235,000$ if the company applies the net worth method to determine the taxable income and smaller than $€ 100,000$ if the company applies the net income method. (The thresholds were reduced from $€ 335,000$ and $€ 200,000$ respectively in 2011.)

- The relevant assets must remain in a domestic permanent establishment of the company for at least one year.

The benefits connected to fulfilling these criteria are twofold: First, an additional depreciation of $20 \%$ of the acquisition or manufacturing costs of new movable assets can be incurred in the year of acquisition or manufacturing and the following four years $(20 \%$ at most in all five years together). The additional depreciation reduces subsequent depreciations accordingly. Second, an investment reserve of up to $40 \%$ of future acquisition or production costs of depreciable assets can be recognized. Income entering the reserve is tax-free upon recognition but is taxed as the respective assets start to be depreciated. The investment reserve is limited to $€ 200,000$. The acquisition or the manufacturing of the asset for which the deduction is 
claimed must be made within three years and it must be used in a domestic permanent establishment (almost) exclusively for business purposes.

For non-corporate entities, business income up to $€ 24,500$ is exempt from the trade tax.

If the annual turnover does not exceed $€ 500,000$ and the profit stays below $€ 50,000$, simplified tax accounting in the form of modified cash accounting may also be used by noncorporate entities.

If turnover did not exceed $€ 17,500$ in the previous fiscal year and does not exceed $€ 50,000$ in the current year, enterprises are exempt from the VAT. If the annual value-added tax payable does not exceed $€ 7,500$, quarterly payments can be made (instead of monthly).

\section{Greece}

Greece does not provide any tax incentives specifically designed for SMEs. There is, however, a scheme that allows establishing tax-free reserves. The reserve amounts to $15-45 \%$ of the amount invested in qualifying undertakings (which includes investments that contribute to improving business, technological development, business competitiveness and regional cohesion). The eligible amount depends on the location of the investment and the size of the company (smaller enterprises receive higher reliefs of $25-45 \%$ instead of 15-40\%). SMEs should therefore receive larger exemptions. The tax-free income must neither be distributed nor capitalized. Up to one third of the exemption is due in the first year of operations of the investment and up to two thirds in the following year. The balance is settled within a maximum of eight years.

For small firms with a turnover of up to $€ 1.5$ million the use of single-entry accounts is allowed; however, this entails an increased tax rate of $33 \%$ instead of the usual $26 \%$ on all income over $€ 50,000$ for partnerships. Corporate entities are usually not eligible for this special scheme.

A disadvantage for SMEs occurs with respect to Greece's treatment of so-called strategic investments. These are investments of at least $€ 15$ million or investments creating at least 150 new jobs. SMEs naturally will not (or only hardly) reach such investment levels. 
Enterprises only need to register for VAT if their turnover exceeds $€ 5,000$ (provision of services) or $€ 10,000$ (sale of goods), respectively. If enterprises use single-entry books, they may also opt for quarterly VAT returns (instead of monthly).

\section{Hungary}

Hungary offers substantial tax incentives that primarily benefit SMEs. SMEs are generally defined according to the definition by the European Commission.

Most importantly, a special tax rate of $10 \%$ applies to the first HUF 500 million $(\approx € 1.6$ million). Beyond the threshold, income is taxed at $19 \%$. Moreover, small businesses are exempt from the innovation tax $(0.3 \%$ of the tax base of the local business tax $)$ and may be exempt from the local business tax (depending on municipalities).

With regard to input-based tax incentives, there are several tax allowances for SMEs. First, $100 \%$ of investment expenses for certain assets can be deducted from the tax base if the SME is solely owned by individuals. The maximum deduction is HUF 30 million $(\approx € 100,000)$. SMEs with less than 20 employees can also benefit from an additional allowance of $200 \%$ of wage costs that are incurred for employees who are at least $50 \%$ disabled. The deductible wage costs per employee cannot exceed the statutory minimum wage. Lastly, micro enterprises with less than five employees and without an outstanding tax liability at the end of the year are subject to an allowance based on the increase in personnel. They are entitled to a deduction equal to the product of the increase in the average annual number of employees compared to the previous year and 12 times the statutory minimum wage.

There is also a tax credit for new investment projects that is available for businesses of all size classes but requires lower minimum investments to be eligible for SMEs:

- Large enterprises: minimum investment is HUF 3 billion $(\approx € 10$ million), 150 new jobs must be created and wage costs need to be increased by at least 600 times the statutory minimum wage.

- Medium-sized enterprises: minimum investment is HUF 500 million $(\approx € 1.6$ million), 50 new jobs must be created and wage costs need to be increased by at least 100 times the statutory minimum wage. 
- Small enterprises: minimum investment is HUF 500 million $(\approx € 1.6$ million), 20 new jobs must be created and wage costs need to be increased by at least 50 times the statutory minimum wage.

The tax credit equals $100 \%$ of the investment value but must not exceed $80 \%$ of the tax liabilities. It is granted in 10 equal instalments.

Another tax credit is offered for SMEs that invest at least HUF 500 million $(\approx € 1.6$ million $)$ and take out a loan from a financial institution to acquire or produce required tangible assets. The credit equals $60 \%$ of the interest paid on the loan with a maximum eligible interest of HUF 6 million $(\approx € 20,000)$. Enterprises from the transport or the agricultural sectors are not eligible.

For SMEs in disadvantaged regions, immediate depreciation of acquisition costs of machinery, equipment and vehicles (excluding cars) is also available.

In addition to these incentives, small businesses in Hungary may also opt for three alternative regimes. The so-called simplified entrepreneurial tax is available for small businesses that are no public companies and whose turnover does not exceed HUF 30 million $(\approx € 100,000)$. Under this regime, taxpayers are taxed at $37 \%$ on turnover increased by VAT. If turnover unexpectedly exceeds HUF 30 million during the fiscal year, an increased tax rate of 50\% applies for the excess. The simplified entrepreneurial tax replaces corporate and personal income taxes, the value-added tax and the company car tax. The regime must not be applied if the taxpayer sells waste products falling under the reverse charge regime for VAT purposes or if certain holding requirements are not met.

Another regime that may be opted for instead of the ordinary corporate income tax is the small company tax. In order to be eligible companies need to fulfill the following criteria:

- average number of employees $\leq 25$;

- expected annual turnover $\leq$ HUF 500 million $(\approx € 1.6$ million $)$;

- expected balance sheet total $\leq$ HUF 500 million $(\approx € 1.6$ million $)$;

- balance of enforceable tax debt $\leq$ HUF 1 million $(\approx € 3,000)$

The small company tax replaces the corporate income tax, the social security tax and training contributions for the taxpayer. The tax is levied at $16 \%$ on accrual profits but it must not be smaller than the personnel costs incurred. 
Lastly, the itemized tax of small businesses can be chosen by businesses with a turnover of less than HUF 6 million. Under this regime, businesses pay HUF 50,000 ( $\approx € 160)$ per fulltime employee and HUF 25,000 $(\approx € 80)$ for each employee not being classified as full-time. These tax payments replace the corporate income tax, the social security tax, the health care charge and the vocational training contribution. If the threshold of HUF 6 million $(\approx € 20,000)$ is exceeded, a tax of $40 \%$ on the excess turnover is charged.

With regard to administrative obligations, small enterprises are subject to less restrictive regulations on transfer pricing and related documentation. Businesses with a turnover of less than HUF 6 million are exempt from the VAT. If the net VAT payable is below HUF 1 million ( $\approx € 33$ million), only quarterly returns need to be filed instead of monthly. If net turnover does not exceed HUF 250,000, $(\approx € 800)$ only annual returns are required. Cash accounting for VAT purposes is allowed up to HUF 125 million $(\approx € 400,000)$.

\section{Ireland}

With regard to the corporate income tax, Ireland does not provide tax incentives specifically for SMEs. However, they may benefit from an exemption of taxable income up to $€ 40,000$ that phases out between $€ 40,000$ and $€ 60,000$. The exemption is restricted to newly founded companies in the first three years of operation, though, and must not exceed the PRSI contributions made (max. $€ 5,000$ per employee).

SMEs also benefit from less restrictive transfer pricing regulations and - if their tax liability does not exceed $€ 200,000$ - less restrictive provisions for preliminary tax payments. No prepayments are required from new businesses that do not expect a tax liability of more than $€ 200,000$ in their first year of operations.

For personal income tax purposes, individuals can deduct up to $€ 150,000$ of the acquisition costs of shares in qualifying unquoted trading SMEs from their taxable income (excess investments can be carried forward). The share in the company must not be higher than $30 \%$ unless the capital of the company does not exceed $€ 500,000$. Holding restrictions and other anti-avoidance rules are in place. The company must either be incorporated and resident in Ireland or be incorporated in an EEA country and resident (a) in Ireland or (b) in another EEA country and carry on business through a branch or agency in Ireland. In addition, the company 
must carry on qualifying trade. The maximum capital the company may raise amounts to $€ 15$ million and $€ 5$ million within any 12 -month period. An even more generous deduction is granted to formerly employed people who invest in a start-up. They can claim a tax refund on income from the last six years (the maximum tax refund is $€ 100,000$ ).

For VAT purposes, businesses are exempt if their turnover does not exceed $€ 37,500$. Moreover, small businesses do only have to file returns and make VAT payments every 6 months (instead of every 2 months) if their VAT payments do not exceed $€ 3,000$ and only every 4 months if payments are below $€ 14,400$.

\section{Italy}

Italy does not provide generally applicable incentives for SMEs with regard to the corporate income tax. SMEs, however, can use simplified rules for determining the tax base of the business tax (IRAP). The simplified rules include standardized lump-sum deductions for expenses incurred.

Moreover, there is a tax credit for $\mathrm{R} \& \mathrm{D}$ expenses in place that is likely to benefit SMEs more than large companies as it is capped at $€ 5$ million. Eligible enterprises need to incur at least $€ 30,000$. In 2014, two different R\&D tax credits were in place. The first one only applied to enterprises with less than $€ 500$ million of turnover. It granted a relief equal to $50 \%$ of R\&D expenses as far as the expenses surpassed the average of the previous three years. The other credit amounted to $35 \%$ of the wage costs that were attributable to newly hired employees in R\&D who were given permanent contracts. The cap for this credit was $€ 200,000$.

Companies in the fields of energy production and supply were not subject to the increased corporate tax rate of $34 \%$ (instead of $27.5 \%$ ) if they had a turnover below $€ 3$ million and taxable income below $€ 300,000$. The surtax for companies in the areas of energy production and supply (6.5\%) has been abolished in 2015, though.

Innovative start-up companies are exempt from stamp duties and registration fees, if the following criteria are fulfilled:

- business not older than 48 months;

- not a result of a merger/acquisition;

- turnover $\leq € 5$ million;

- no profit distributions; 
- sole purpose of innovative high-technology products and services.

Additionally, at least one out of the following conditions are met:

- R\&D expenses amount to at least $15 \%$ of revenues or costs;

- one third of all employees are highly qualified;

- the respective company is holder or licensee of patent right connected to its activity.

Newly founded companies - in contrast to established ones - may also fully deduct expenses incurred for studies, research, advertising and entertainment as well as the costs of formation in the first year, in which they incur gross receipts.

Shareholders of innovative SMEs and start-ups can deduct $20 \%$ of their respective investments from taxable income. The maximum deduction amounts to $€ 1.8$ million. Furthermore, the shareholding has to satisfy, i.a., the following criteria:

- equity share not larger than $€ 2.5$ million;

- shares must be held for at least 2 consecutive years;

- SME must not be older than 7 years, not have gross production of more than $€ 5$ million and it must be active in the field of highly technological and innovative products.

Investors of venture capital funds are also exempt with regard to their proceeds from the fund if the fund only invests in non-listed, Italian small companies (turnover $\leq € 50$ million) that are not exempt from corporate income tax, have not been incorporated for more than 36 months and are controlled by individual shareholders.

For purposes of the value-added tax, enterprises that do not have more than $€ 50,000$ of turnover can file quarterly returns (instead of monthly). There is no registration threshold. Each business needs to register for the value-added tax.

\section{Latvia}

Latvia provides micro enterprises with the option to tax turnover instead of the ordinary corporate income tax. Companies are eligible if their turnover does not exceed $€ 100,000$ and 
if they do not employ more than 5 employees who must not earn more than $€ 720$ per month. Shareholders have to be exclusively individuals. Under the regime the following tax rates apply:

- $9 \%$ on turnover from $€ 0$ to $€ 7,000$;

- $12 \%$ on turnover from $€ 7,001$ to $€ 100,000$;

- $20 \%$ on turnover beyond $€ 100,000$.

In the three first years the regime is applied, the lowest rate of $9 \%$ is granted for all revenues up to $€ 100,000$. The turnover tax replaces the corporate income tax $(15 \%)$ and the social security contributions that need to be paid by the employer. Penalty taxes apply if either the wage threshold is exceeded ( $20 \%$ on excess wages) or more than five employees are hired ( $2 \%$ tax rate increase per employee).

In Latvia's special economic zones, a tax credit is available for new investments. For small and micro companies, the credit equals $55 \%$ of the investment value, whereas it is limited to $45 \%$ for medium-sized enterprises and to $35 \%$ for large ones. For each size class, the credit must not exceed $80 \%$ of the tax liability. The definition of the size classes corresponds to the definition by the European Commission. With regard to the standard tax credit, however, SMEs are by trend disadvantaged because only investments of at least $€ 10$ million are eligible. The credit grants a relief of $25 \%$ of the investment value up to $€ 50$ million and $15 \%$ on expenditure beyond the threshold.

For VAT purposes, enterprises are exempt if their turnover does not exceed $€ 50,000$. Businesses beyond the threshold have to file monthly returns. If supplies are below $€ 14,228.72$, six-monthly returns are sufficient. Cash accounting for the value-added tax is allowed up to $€ 100,000$. For the corporate income tax, annual tax returns need to be filed sooner by SMEs (4 months after the end of the fiscal year) than by large enterprises (7 months).

\section{Lithuania}

Lithuania has extensive tax incentives for micro companies. Foremost, enterprises enjoy a reduced corporate income tax rate of 5\% (instead of 15\%) if they meet the following criteria: 
- number of employees $\leq 10$;

- taxable income $\leq$ LTL 1 million $(\approx € 300,000)$;

- corporation must not be owned by more than $50 \%$ by an owner/a family/a group of persons who also own(s) a sole proprietorship or other companies by more than $50 \%$.

Companies meeting these criteria whose income does not exceed $€ 150,000$ are also entitled to free depreciation of fixed assets (excluding buildings). When benefitting from the reduced tax rate, no maximum for the use of loss carry-forwards applies $(70 \%$ of the current year's income for large entities).

Additionally, newly founded businesses and companies with taxable income of less than $€ 30,000$ in the last three years of operation are allowed to determine their income based on cash accounting. Large enterprises, on the other hand, tend to be favored in special economic zones, where several tax advantages only apply to investments of at least $€ 1$ million.

With regard to the value-added tax, enterprises are exempt if their turnover does not exceed $€ 45,000$. Registration is also mandatory, if goods from other EU countries are acquired for at least $€ 14,000$.

\section{Luxembourg}

Luxembourg does not provide any tax incentives that refer specifically to SMEs as defined by the European Commission. However, small companies in particular should benefit from the reduced corporate income tax rate of $20 \%$ (instead of 21\%) that applies to companies with an income below $€ 15,000$ as well as from the progressive schedule of the minimum tax. (The amount of minimum tax payable depends on the balance sheet total.) Moreover, income up to $€ 17,500$ is not subject to the municipal business tax. The generally applicable tax credit (7\% or $8 \%$ on qualifying tangible and depreciable assets) may also favor SMEs as it is capped at $€ 150,000$. Beyond the threshold, only $2 \%$ of the qualifying expenditure is creditable. Further advantages for SMEs include higher non-tax grants for R\&D projects.

$25 \%$ of the income by certain new businesses fostering the growth of the economy may be exempt from corporate income taxation. 
There are also incentives for venture capital investments. Special venture capital vehicles (SICAR) are exempt from corporate income tax and qualifying investments up to $€ 5$ million or $30 \%$ of taxable income, respectively, can be deducted from the tax base by investors. The latter relief only applies if the capital finances enterprises that introduce new technologies or fabrications.

For VAT purposes, enterprises do only have to register if their turnover does exceed $€ 25,000$ or intra-community acquisitions exceed $€ 10,000$. Returns need to be filed annually if the turnover is below $€ 112,000$ and quarterly if it is below $€ 620,000$ (instead of monthly). VAT can be paid on a cash basis (receipts method) if the turnover of the taxpayer is below $€ 500,000$.

Malta

Malta provides SMEs with increased tax credits for new investments or major extensions of existing operations in a multitude of manufacturing and service industries. Eligible activities include:

- production, manufacturing and processing of goods, materials, commodities, equipment, plant and machinery;

- activities related to information technology,

- call centers

- R\&D and innovation of products and processes as well as activities related ecoinnovation, water treatment, environmental solutions and biotechnology;

- tertiary education, filming and cultural restoration as well as the provision of large-scale cultural, creative and trade facilities

- private healthcare services.

Creditable costs include expenditures in tangible or intangible assets incurred by such undertakings in the preceding year or wage costs for jobs directly created by the initial investment. Taxpayers may deduct $35 \%$ (micro and small undertakings) or $25 \%$ of eligible costs from their tax liabilities (instead of $15 \%$ for large enterprises). Cash grants are available instead of the tax credit if the makes a substantial contribution to the economic development of Malta. SMEs are defined according to the definition of the European Commission. 
An extra credit is available for research projects. The size of the credit is measured as a percentage of eligible personnel costs, current costs, overhead, costs for contract research (not more than $25 \%$ of total eligible costs), costs for registering intellectual property (IP), depreciation of land and buildings and capital expenditures for fixed assets other than land and buildings. Eligible percentages are as follows:

- small and micro enterprises: 70\% for industrial research projects (80\% for collaborative projects with research and knowledge-dissemination organizations); $45 \%$ for experimental research projects (60\% for collaborative projects);

- medium-sized enterprises: $60 \%$ for industrial research projects $(75 \%$ for collaborative projects); $35 \%$ for experimental research projects (50\% for collaborative projects);

- large enterprises: $50 \%$ for industrial research projects (65\% for collaborative projects); $25 \%$ for experimental research projects ( $40 \%$ for collaborative projects).

Projects must be finished within three years in order to be eligible. Unused credits can be carried forward indefinitely.

Another tax credit exists for small enterprises. The credit amounts to $45 \%$ (65\% in the region of Gozo) of wage costs for new employees, refurbishing costs and costs incurred for machinery, equipment and technology. The maximum credit amounts to $€ 30,000$ (€ 50,000 for start-ups). Eligible businesses must have at least one and less than 30 full-time employees, a turnover of less than $€ 10$ million and be registered for the value-added tax and not be part of a group.

Enterprises are exempt from VAT if their turnover does not exceed $€ 35,000$ (supply of goods), $€ 24,000$ (supply of service with low value added) or $€ 14,000$ (other activities), respectively. Professional service providers and retailers with less than $€ 2$ million of turnover may account for VAT on a cash basis.

\section{Netherlands}

The Netherlands do not provide any incentives that are exclusively restricted to small and medium-sized enterprises. Some provisions, however, particularly benefit SMEs due to maximum absolute thresholds limiting eligible income or expenses. First, there is a 
progressive corporate income tax schedule in place that taxes income up to $€ 200,000$ at $20 \%$ and the excess at $25 \%$.

Second, the general investment deduction for small-scale investments in certain assets is only applicable if the total annual qualifying costs are between $€ 2,300$ and $€ 309,693$. Moreover, the deductible percentage decreases as eligible costs increase. The following sliding scale applies:

- $28 \%$ if the total of qualifying investments is between $€ 2,300$ and $€ 55,745$;

- $€ 15,609$ if the total of qualifying investments is between $€ 55,745$ and $€ 103,231$;

- $€ 15,609$ less $7.56 \%$ of the invested amount exceeding $€ 103,231$ if the total of qualifying investments is between $€ 103,231$ and $€ 309,693$;

- $0 \%$ if the total of qualifying investments exceeds $€ 309,693$.

The thresholds and deductible amounts are adjusted for inflation annually.

A regime of free depreciation was introduced in 2015. It applies to certain assets that are in the interest of the furtherance of economic development with a maximum investment value of $€ 25$ million. Beyond the threshold EU admission is necessary. For R\&D activities, a wage tax reduction of $35 \%$ for involved employees is available up to $€ 250,000$ per employee (50\% for start-ups). Beyond the threshold, only $14 \%$ of eligible wage costs can be deducted. The maximum deduction amounts to $€ 14$ million. Another deduction applies to individual entrepreneurs conducting R\&D. They are entitled to a lump-sum allowance of $€ 12,310$ or $€ 18,467$ for the first five years of his entrepreneurial activity. Net losses arising from this deduction can be carried back for three years or carried forward for nine years.

For VAT purposes, businesses may make quarterly payments if the amount payable per quarter does not exceed $€ 7,000$ (instead of monthly). Yearly payments are allowed if quarterly amounts are below $€ 2,000$. Natural persons whose VAT liability does not exceed $€ 1,883$ are fully exempt from VAT.

\section{Poland}

Poland provides several tax incentives for SMEs. First, small and medium-sized enterprises may receive a tax credit of up to $75 \%$ of investment costs for investing in new technologies. 
The credit must not exceed $70 \%$ of the sales value of the products produced with the new technology. Lower percentages may apply depending on the size of the company and the project location. The technology needs to be new and sufficiently innovative (must not have been used for more than five years globally). The maximum credit is PLN 4 million $(\approx € 950,000)$ and the project must not involve investments of more than $€ 50$ million. SMEs are defined according to the definition by the European Commission.

Second, SMEs receive tax benefits if they invest in so-called special economic zones. For investments of at least $€ 100,000$, enterprises benefit from investment allowances on either the investment costs (costs for land and buildings only enter the calculation base with 5\% and $40 \%$, respectively) or the personnel costs of newly hired employees over two years. While large enterprises can only apply an allowance of $30 \%$ to $50 \%$ (depending on the zone), medium-sized enterprises are entitled to an additional $10 \%$ and small enterprises to an additional $20 \%$. In order to be eligible for the allowance, activities must be carried on for at least 3 years without changing ownership and new jobs must be created and kept for this period.

A special regime of depreciation is also in place in Poland. Under the regime, enterprises with a turnover (incl. VAT) of less than $€ 1.2$ million are allowed to immediately depreciate the costs of certain fixed assets up to an amount of $€ 50,000$. The same exception applies to startups. The latter may also get a waiver for the income tax due in the first or second year of operations (depending on the exact date of initiation) if they are small or micro companies. The tax, however, must be repaid in the subsequent five years in equal instalments.

For the VAT purposes, small taxpayers with less than $€ 1.2$ million of turnover (incl. VAT) can opt for quarterly tax payments instead of monthly payments. Moreover, cash-basis accounting is available for these enterprises. Eligible taxpayers can also opt for quarterly advance income tax payments instead of monthly.

\section{Portugal}

Portugal offers various kinds of tax incentives targeted at SMEs. Starting with the corporate income tax rate, the first $€ 15,000$ of income of SMEs (according to the definition of the European Commission) are taxed at a reduced rate of $17 \%$ (instead of $23 \%$ ). Moreover, SMEs 
benefit from the progressive structure of the state surtax that is levied at the following rates (for all enterprises irrespective of their size):

- $0 \%$ on income up to $€ 1.5$ million;

- $3 \%$ on income between $€ 1.5$ million and $€ 7.5$ million;

- $5 \%$ on income between $€ 7.5$ million and $€ 35$ million;

- $7 \%$ on income beyond $€ 35$ million.

Tax credits are also available for SMEs in Portugal. First, there is a credit of $10 \%$ on retained earnings. The credited amount needs to be reinvested in eligible assets within two years. Another credit is granted for R\&D expenditures (capital expenditure excluding land and buildings, costs for personnel and contract research and other operating costs). While the creditable amount is generally calculated as $32.5 \%$ of eligible costs, new SMEs can claim $47.5 \%{ }^{231}$ In addition, they may include $100 \%$ of personnel costs instead of only $90 \%$ as is usual. Unused credits can be carried forward for six years.

The third credit refers to investments that are designed to internationalize the Portuguese economy. The credit is available to all enterprises for non-EU member states but is restricted to SMEs for investments within the EU. The minimum investment is $€ 250,000$ and the credit amounts to $10-20 \%$ of the investment. It must neither exceed $25 \%$ of the tax liability nor $€ 997,595.79$. There is also an exemption of dividends from non-resident subsidiaries that is restricted to non-EU countries for large companies whereas SMEs can benefit in both the EU and non-member states. In order to be eligible, the holding must be at least $10 \%$ one year prior to the dividend, the investment must have led to a newly created non-resident company or an acquisition of such and the investment must have amounted to at least $€ 250.000$.

Another investment tax credit applies to all enterprises but is especially beneficial to SMEs as smaller investment amounts are promoted more generously in relative terms. The credit reduces the income tax payable by $25 \%$ of investments in fixed assets up to $€ 5$ million. Beyond this threshold only $10 \%$ are deductible and the credit must not exceed $50 \%$ of the tax liability. For start-ups, the credit may amount to $100 \%$ of the tax liability in the first three years of operations. The incentive only applies in certain sectors such as tourism and mining and requires an investment period of at least five years. The credit can be carried forward for 4 years. The incentive also includes exemptions from the property tax, the property transfer

\footnotetext{
${ }^{231}$ In addition, an incremental tax credit $(50 \%)$ is available for all businesses on all eligible R\&D expenditures as far as they exceed the average spending of the previous two fiscal years.
} 
tax and stamp duties on acquired land. On the other hand, SMEs may be disadvantaged with regard to contractual tax incentives for so-called strategic investment that are only granted if certain minimum investments are made ( $€ 3$ million). The related tax credit of $10 \%$ to $25 \%$ is also accompanied by exemptions from property tax, the property transfer tax and stamp duties.

A deduction of 5\% from taxable income applies to SMEs on all capital contributions in cash by shareholders upon incorporation or subsequent capital increases. Eligible SMEs must be owned by individuals or qualifying venture capital investors. Shareholders on the other hand are exempt from taxation with $50 \%$ of their capital gains from the sale of participations in unlisted small and micro companies.

For micro companies - either incorporated or not incorporated - Portugal also offers a very simplified accounting regime to determine taxable income. It applied to micro enterprises that fulfill the following criteria:

- no. of employees $\leq 5$;

- turnover $\leq € 500,000$;

- balance sheet total $\leq € 500,000$;

- income $\leq € 200,000$.

If these criteria are met, small businesses may determine taxable income as follows:

- $4 \%$ of sales and services rendered for hotel, food and beverage activities;

- $75 \%$ of income derived from the official schedule of activities approved by order of the Minister of Finance

- $10 \%$ of remaining income arising from services and business-related subsidies

- $95 \%$ of income from the sale or temporary use of rights of intellectual or industrial property and other investment income

- $100 \%$ of acquisition value of charge increases in wealth

Another simplified accounting system is in place for enterprises that fulfill the following criteria:

- no. of employees $\leq 50$

- turnover $\leq € 3$ million

- balance sheet total $\leq € 1,5$ million 
Further administrative reliefs for micro enterprises exist with regard to the value-added tax. While individual entrepreneurs with a turnover of less than $€ 9,976$ are completely exempt, enterprises with less than $€ 650,000$ do only need to file quarterly returns (instead of monthly). Micro enterprises are also subject to reduced periods of safekeeping for supporting documents.

\section{Romania}

Romania provides a mandatory special tax regime for micro companies under which corporate income tax has to be paid at $3 \%$ on turnover. The regime applies to fully privately owned enterprises with income below $€ 65,000$ except for enterprises deriving income in the banking, gambling, consultancy or management sector. Before being repealed in 2010 and reintroduced in 2011, the regime used to be applied on a voluntary basis.

If businesses do not have more than $€ 65,000$ of turnover, they are also exempt from the value-added tax.

\section{Slovak Republic}

The Slovak Republic does not have any specific tax provisions for small and medium-sized enterprises except for size-adjusted eligibility criteria for R\&D investment incentives. Small enterprises may even be disadvantaged with regard to some investment incentives as these require minimum investments of up to $€ 3$ million.

For new companies, start-up expenses are deductible when incurred.

For VAT purposes, small businesses are exempt if their turnover is below $€ 49,790$.

\section{Slovenia}

Slovenia does not provide tax incentives specifically designed for SMEs. They are, however, subject to less restrictive holding requirements ( 3 instead of 5 years) for assets that qualify for the investment deduction in the region of Pomurje. The deduction amounts to $70 \%$ of incurred costs of eligible equipment and intangibles with a maximum allowance of $€ 30,000$. There is also a general investment allowance of $40 \%$ of expenditures on intangibles and equipment in 
place, the maximum threshold of $€ 30,000$ for this allowance has been abolished, though. Consequently, there is no advantage for SMEs compared to large enterprises.

Venture capital companies are generally tax exempt with their investments.

Administratively, there are some minor reliefs for SMEs reduced penalties in case of insufficient or delayed tax payments or shortened audit periods. Moreover, businesses are exempt from the value-added tax if their turnover does not exceed $€ 50,000$.

\section{Spain}

Spain is a country with multiple kinds of tax incentives for SMEs. Accelerated depreciation is offered as well as allowances, tax credits and special tax rates. In order to be considered an SME, firms generally need to have a turnover below $€ 10$ million ( $€ 8$ million until 2010).

There are two schemes of accelerated depreciation. The first one allows depreciation at $200 \%$ of the normal rates. The regime includes all newly acquired tangible fixed and intangible assets. Alternatively, free depreciation is available for SMEs if they increase the annual average of personnel in the 24 months following the first use of the asset. The maximum amount to be freely depreciated equals the product of $€ 120,000$ and the percentage increase in personnel. Assets with acquisition costs below $€ 601.01$ maybe freely depreciated up to a threshold of $€ 12,020.24$ in any case. In 2013 and 2014, there were further schemes that allowed SMEs to depreciate all tangible fixed assets if they were purchased with proceeds stemming from capital gains. Moreover, ordinary depreciation rates for tangible fixed assets, intangibles and immovable property were not temporarily reduced by $30 \%$ as was the case for large enterprises.

SMEs with less than 50 employees also qualify for two tax credits that are granted for the hiring of new employees with indefinite full-time employment contracts. The first one amounts to $€ 3,000$ for each new employee under the age of 30 . The other tax credit is provided for the hiring of employees who have received unemployment payments for at least three months at the time of hiring. The latter one yields $50 \%$ of the outstanding unemployment payments for one year for the enterprise as well as $25 \%$ of the outstanding payments for the employee. The R\&D and innovation tax credits may also favor SMEs as they are capped at $€ 3$ million and $€ 1$ million, respectively. 
Besides tax credits and accelerated depreciation schemes, special corporate income tax rates apply for SMEs which meet the following criteria:

- net revenue $\leq € 5$ million;

- no. of employees $\leq 25$;

- level of employment needs to be retained or increased relative to 2009.

If the criteria are met, a special corporate income tax rate of $20 \%$ applies for the first $€ 300,000$ of income. All income beyond the threshold is taxed at 25\%. SMEs that do not meet the above criteria incur a reduced tax rate of $25 \%$ on the first $€ 300,000$ of income instead of being subject to the standard CIT rate of $28 \%$. The normal rate, however, will be further decreased to $25 \%$ in 2016 (coming from $30 \%$ in 2014) thus making the special rate irrelevant. Another rate exists for newly founded companies (not only SMEs) that are not part of a group. In their first two years with positive income, they are subject to a CIT rate of only $15 \%$ on their first $€ 300,000$ of income and $20 \%$ on income beyond the threshold. The newly founded company must not be held by shareholders having performed similar activities before in order to be eligible.

Further SME tax rates apply in several regions of Spain. In Alava, Vizcaya and Guipúzcoa, a special rate of $24 \%$ applies to SMEs (instead of the usual $28 \%$ in Basque Country). In Navarre, a rate of $23 \%$ (19\%) instead of 25\% applies for SMEs that employ at least one person and have an annual turnover below $€ 9$ million ( $€ 1$ million). A slight disadvantage for SMEs is the regressive structure of the surcharge for members of the Chamber of Commerce. While $0.75 \%$ is charged on income up to $€ 60,101$, the rate decreases gradually to only $0.01 \%$ on income beyond $€ 24$ million. The surcharge is tax deductible though.

Besides the abovementioned provisions, Spain offers the following tax incentives for SMEs:

- exemption from the local business tax (IAE) if turnover is below $€ 1$ million;

- special deduction of up to $10 \%$ of taxable income; deduction must enter a special reserve that is used in the following 5 years to balance out tax losses (otherwise taxation at the end of the 5-year period);

- option to establish a special provision for bad debt not qualifying for the general provision. The maximum provision amounts to $1 \%$ of the existing balance of debt at the end of the tax period; 
- exemption of $99 \%$ of gains from venture capital investments in non-financial SMEs operating in the field of technological innovation by qualifying venture capital companies and funds; exemption includes gains from the sale of shares and other participations that have been held for at least one and not more than 15 years. (An extension to 20 years may be granted.)

With regard to administrative facilitations, Spain offers relaxed transfer pricing requirements for all SMEs with intercompany transactions below $€ 100,000$. For VAT purposes, a special regime of cash accounting can be applied if an enterprise's turnover does not exceed $€ 2$ million. If turnover is below $€ 35,000$, only annual VAT returns need to be filed.

\section{Sweden}

Sweden does not provide any tax incentives directly targeted at SMEs. Individual investors, however, can claim a deduction of $50 \%$ of the acquisition costs they incur when acquiring shares of small companies at the formation or subsequent share issuances. The shares must be held for at least five years. The deduction can be made from capital income. The maximum deduction amounts to SEK 650,000 $(\approx € 100.000)$. The maximum total investment per company is SEK 20 million ( $\approx € 3$ million) per year. Furthermore the company must fulfill the following criteria (on a group level):

- payment of annual salaries of at least SEK 300,000 ( $\approx € 45,000)$;

- fewer than 50 employees or active partners;

- net turnover $\leq$ SEK 80 million $(\approx € 12$ million);

- balance sheet total $\leq \mathrm{SEK} 80$ million $(\approx € 12$ million $)$.

For VAT purposes, businesses can use cash-based accounting if their turnover does not exceed SEK 3 million ( $\approx € 450,000)$. Returns have to be file monthly unless the turnover does not exceed SEK 40 million $(\approx € 6$ million). Then quarterly returns are sufficient. Enterprises with a turnover of less than SEK 1 million $(\approx € 150,000)$ can opt for yearly returns. No registration threshold exists.

\section{United Kingdom}


The United Kingdom provides an investment allowance for R\&D activities that is especially beneficial for SMEs. Under the regime, all enterprises are allowed to deduct an additional $30 \%$ of their R\&D expenses from taxable income (only revenue expenditure, no capital expenditure). SMEs, however, are entitled to an additional $100 \%$, resulting in a total allowance of $130 \%$. In order to be eligible, the following criteria need to be met:

- number of employees $\leq 500$;

- turnover $\leq € 100$ million;

- balance sheet total $\leq € 86$ million.

Loss-making SMEs may surrender their R\&D losses in return for a tax credit equal $14.5 \%$ of the underlying loss. The credit is refunded immediately. The relief from the SME-specific regime must not exceed $£ 7.5$ million $(\approx € 9$ million). If an SME incurs eligible expenditures beyond the threshold, however, the scheme for large enterprises applies.

Further provisions that may benefit SMEs include the following:

- There is an annual investment allowance of $100 \%$ on the first $£ 500,000$ $(\approx € 650,000)$ of expenditure on plant and machinery in place. Alternatively, a first-year allowance for certain assets can be claimed. Both incentives are generally applicable and not restricted to SMEs.

- There is no cap on deductible external finance expenses if an SME is part of a taxable group.

- Special corporate income tax rates apply for companies engaged in the production of oil and gas: income up to $£ 300,000(\approx € 400,000)$ is taxed at a rate of $19 \%$ instead of $30 \%$; marginal relief is available for income up to $£ 1.5$ million $(\approx € 2$ million).

- SMEs are subject to simplified provisions for the valuation of intellectual property.

With regard to the value-added tax, enterprises are exempt if their annual turnover does not exceed $£ 81,000(\approx € 100,000)$. A simplified VAT scheme applies for enterprises with a turnover below $£ 150,000(\approx € 200,000)$ and cash-based accounting for VAT is allowed up to $£ 1.35$ million $(\approx € 1.8$ million). 
Annex 2: Empirical Studies on the Relation of Firm Size and Job Creation

Table A1: Empirical studies on the relationship of firm size, firm growth and job creation

\begin{tabular}{|c|c|c|c|c|c|}
\hline Author(s) & Year & Publication & Data & Estimation design & Main findings \\
\hline Amirkhalkhali/Mukhopadhyay & 1993 & Eastern Economic Journal & $\begin{array}{l}\text { - large U.S. firms } \\
\text { - all sectors } \\
\text { - } 1965-1987\end{array}$ & - regression & $\begin{array}{l}\text { - negative relationship between firm } \\
\text { size and firm growth (employment) }\end{array}$ \\
\hline Armington/Odle & 1982 & The Brookings Review & $\begin{array}{l}\text { - U.S. establishments } \\
\text { (private sector) } \\
\text { - all sectors } \\
\text { - } 1978-1980\end{array}$ & $\begin{array}{l}\text { - comparison of } \\
\text { growth rates by } \\
\text { size classes }\end{array}$ & $\begin{array}{l}\text { - negative relationship between } \\
\text { establishment size and rate of net } \\
\text { job creation }\end{array}$ \\
\hline Audretsch/Elston & 2006 & $\begin{array}{l}\text { Entrepreneurship, } \\
\text { Growth, and Innovation } \\
\text { (textbook) }\end{array}$ & $\begin{array}{l}\text { - } \text { all publicly traded } \\
\text { German firms } \\
\text { - all sectors } \\
\text { - } 1970-1984\end{array}$ & - regression & $\begin{array}{l}\text { positive relationship between firm } \\
\text { size and firm growth (employment) }\end{array}$ \\
\hline Audretsch/Klomp/Santarelli/Thurik & 2004 & $\begin{array}{l}\text { Review of Industrial } \\
\text { Organization }\end{array}$ & $\begin{array}{l}\text { - Dutch firms } \\
\text { - hospitality sector } \\
\text { - } 1987-1991\end{array}$ & $\begin{array}{l}\text { - } \text { regression } \\
\text { - comparison of } \\
\text { growth rates by } \\
\text { size classes }\end{array}$ & $\begin{array}{l}\text { - no clear relationship between firm } \\
\text { size and firm growth (employment) }\end{array}$ \\
\hline Audretsch/Santarelli/Vivarelli & 1999 & $\begin{array}{l}\text { International Journal of } \\
\text { Industrial Economics }\end{array}$ & $\begin{array}{l}\text { - Italian start-ups } \\
\text { - manufacturing } \\
\text { - } 1987-1993 \\
\end{array}$ & - regression & $\begin{array}{l}\text { - negative relationship between firm } \\
\text { size and firm growth (employment) } \\
\text { among surviving start-ups }\end{array}$ \\
\hline Baldwin/Picot & 1995 & $\begin{array}{l}\text { Small Business } \\
\text { Economics }\end{array}$ & $\begin{array}{l}\text { - Canadian firms } \\
\text { - manufacturing } \\
\text { - } 1970-1990\end{array}$ & $\begin{array}{l}\text { - comparison of } \\
\text { growth rates by } \\
\text { size classes }\end{array}$ & $\begin{array}{l}\text { - negative relationship between plant } \\
\text { size and rate of net job creation } \\
\text { - negative net job creation among } \\
\text { large plants }\end{array}$ \\
\hline Barnes/Haskel & 2002 & Working paper & $\begin{array}{l}\text { - UK firms } \\
\text { - manufacturing } \\
\text { - } 1980-1991\end{array}$ & $\begin{array}{l}\text { - comparison of } \\
\text { growth rates by } \\
\text { size classes }\end{array}$ & $\begin{array}{l}\text { - negative relationship between } \\
\text { establishment size and rate of net/ } \\
\text { job creation } \\
\text { - negative net job creation among } \\
\text { establishments with } 20+\text { employees }\end{array}$ \\
\hline
\end{tabular}




\begin{tabular}{|c|c|c|c|c|c|}
\hline Author(s) & Year & Publication & Data & Estimation design & Main findings \\
\hline Becchetti/Trovato & 2002 & $\begin{array}{l}\text { Small Business } \\
\text { Economics }\end{array}$ & $\begin{array}{l}\text { - Italian firms }(10+ \\
\text { employees) } \\
\text { - manufacturing } \\
\text { - } 1989-1997\end{array}$ & - regression & $\begin{array}{l}\text { - negative relationship between firm } \\
\text { size and firm growth (employment) } \\
\text { among firms with less than } 100 \\
\text { employees } \\
\text { - no clear relationship between firm } \\
\text { size and firm growth (employment) } \\
\text { among firms with } 100+\text { employees }\end{array}$ \\
\hline Birch & 1981 & The Public Interest & $\begin{array}{l}\text { - U.S. establishments } \\
\text { - all sectors } \\
\text { - 1969-1976 }\end{array}$ & $\begin{array}{l}\text { - comparison of } \\
\text { growth rates by } \\
\text { size classes }\end{array}$ & $\begin{array}{l}\text { - negative relationship between firm } \\
\text { size and rate of net job creation } \\
\text { - new businesses account for majority } \\
\text { of job creation }\end{array}$ \\
\hline Birch & 1987 & $\begin{array}{l}\text { Job Creation in America } \\
\text { (textbook) }\end{array}$ & $\begin{array}{l}\text { - U.S. establishments } \\
\text { - all sectors } \\
\text { - 1969-1985 }\end{array}$ & $\begin{array}{l}\text { - comparison of } \\
\text { growth rates by } \\
\text { size classes / age } \\
\text { classes }\end{array}$ & $\begin{array}{l}\text { - negative relationship between } \\
\text { establishment size and rate of net } \\
\text { job creation (except for very large } \\
\text { establishments) } \\
\text { - negative net job creation among } \\
\text { establishments with } 100+ \\
\text { employees }\end{array}$ \\
\hline Bottazzi/Dosi/Lippi/Pammolli/Riccaboni & 2001 & $\begin{array}{l}\text { International Journal of } \\
\text { Industrial Organization }\end{array}$ & $\begin{array}{l}\text { - large international } \\
\text { firms } \\
\text { - } \text { pharmaceutical sector } \\
\text { - } 1987-1997\end{array}$ & $\begin{array}{l}\text { - comparison of } \\
\text { size distribution } \\
\text { functions }\end{array}$ & $\begin{array}{l}\text { - no clear relationship between firm } \\
\text { size and firm growth (employment) }\end{array}$ \\
\hline Broersma/Gautier & 1997 & $\begin{array}{l}\text { Small Business } \\
\text { Economics }\end{array}$ & $\begin{array}{l}\text { - } \text { all Dutch firms (10+ } \\
\text { employees) } \\
\text { - manufacturing } \\
\text { - } 1978-1991\end{array}$ & $\begin{array}{l}\text { - comparison of } \\
\text { growth rates by } \\
\text { size classes }\end{array}$ & $\begin{array}{l}\text { - negative relationship between firm } \\
\text { size and rate of net/gross job } \\
\text { creation } \\
\text { - negative net job creation among } \\
\text { firms with 50+ employees } \\
\text { - only new businesses account for } \\
\text { positive net job creation }\end{array}$ \\
\hline Buckley/Dunning & 1984 & Kyklos & $\begin{array}{l}\text { - large international } \\
\text { firms } \\
\text { - industrial firms } \\
\text { - } 1972-1977\end{array}$ & - regression & $\begin{array}{l}\text { - negative relationship between firm } \\
\text { size and firm growth (sales) }\end{array}$ \\
\hline Cefis/Ciccarelli/Orsenigo & 2007 & Structural Change and & - Italian firms & - Bayesian & - no clear relationship between firm \\
\hline
\end{tabular}




\begin{tabular}{|c|c|c|c|c|c|}
\hline Author(s) & Year & Publication & Data & Estimation design & Main findings \\
\hline & & Economic Dynamics & $\begin{array}{l}\text { - } \text { pharmaceutical } \\
\text { industry } \\
\text { - } 1987-1998\end{array}$ & $\begin{array}{l}\text { hierarchical } \\
\text { model estimation }\end{array}$ & size and firm growth (employment) \\
\hline Chen/Lu & 2003 & $\begin{array}{l}\text { Applied Economics } \\
\text { Letters }\end{array}$ & $\begin{array}{l}\text { - } \text { publicly traded } \\
\text { Taiwanese firms } \\
\text { - all sectors } \\
\text { - } 1988-1999\end{array}$ & - regression & $\begin{array}{l}\text { - negative relationship between firm } \\
\text { size and firm growth (fixed assets) } \\
\text { only in some sectors }\end{array}$ \\
\hline Davidsson/Lindmark/Olofsson & 1998 & $\begin{array}{l}\text { Small Business } \\
\text { Economics }\end{array}$ & $\begin{array}{l}\text { - } \text { all Swedish plants } \\
\text { - } \text { all sectors } \\
\text { - } 1989-1994\end{array}$ & $\begin{array}{l}\text { - comparison of } \\
\text { growth rates by } \\
\text { size classes }\end{array}$ & $\begin{array}{l}\text { - negative relationship between firm } \\
\text { size and firm growth (employment) } \\
\text { - negative relationship between firm } \\
\text { age and firm growth (employment) }\end{array}$ \\
\hline Davis/Haltiwanger/Schuh & 1996 & $\begin{array}{l}\text { Small Business } \\
\text { Economics }\end{array}$ & $\begin{array}{l}\text { - U.S. plants } \\
\text { - manufacturing } \\
\text { - } 1972-1988\end{array}$ & $\begin{array}{l}\text { - comparison of } \\
\text { growth rates by } \\
\text { size classes }\end{array}$ & $\begin{array}{l}\text { - no clear relationship between plant } \\
\text { size and net job creation (contrary } \\
\text { results driven by methodological } \\
\text { problems) }\end{array}$ \\
\hline Davis/Haltiwanger/ Schuh & 1996 & $\begin{array}{l}\text { Job Creation and } \\
\text { Destruction (textbook) }\end{array}$ & $\begin{array}{l}\text { - U.S. plants } \\
\text { - manufacturing } \\
\text { - } 1972-1988\end{array}$ & $\begin{array}{l}\text { - comparison of } \\
\text { growth rates by } \\
\text { size classes }\end{array}$ & $\begin{array}{l}\text { - no clear relationship between plant } \\
\text { size and net job creation } \\
\text { - only new plants ( } 5 \text { years) account } \\
\text { for net job creation } \\
\text { - positive net job creation by large } \\
\text { plants }\end{array}$ \\
\hline de Wit/de Kok & 2014 & $\begin{array}{l}\text { Small Business } \\
\text { Economics }\end{array}$ & $\begin{array}{l}\text { - population of EU-27 } \\
\text { businesses } \\
\text { - all sectors } \\
\text { - } 2002-2012\end{array}$ & $\begin{array}{l}\text { - comparison of } \\
\text { growth rates by } \\
\text { size classes }\end{array}$ & $\begin{array}{l}\text { negative relationship between firm } \\
\text { size and rate of net job creation } \\
\text { (decreases in firm size at } \\
\text { diminishing rate) }\end{array}$ \\
\hline $\begin{array}{l}\text { de Kok/Vroonhof/Verhoeven/ } \\
\text { Timmermans/Kwaak/Snijders/ Westhof }\end{array}$ & 2011 & Project report & $\begin{array}{l}\text { - all EU firms } \\
\text { - all sectors } \\
\text { - } 2002-2010\end{array}$ & $\begin{array}{l}\text { - comparison of } \\
\text { growth rates by } \\
\text { size classes }\end{array}$ & $\begin{array}{l}\text { - negative relationship between firm } \\
\text { size and rate of net job creation }\end{array}$ \\
\hline Del Monte/Papagni & 2003 & Research Policy & $\begin{array}{l}\text { - Italian firms } \\
\text { - manufacturing } \\
\text { - 1989-1997 }\end{array}$ & - regression & $\begin{array}{l}\text { - no clear relationship between firm } \\
\text { size and firm growth (sales) }\end{array}$ \\
\hline Droucopoulos & 1982 & Journal of Economic & - large international & - regression & - no clear relationship between firm \\
\hline
\end{tabular}




\begin{tabular}{|c|c|c|c|c|c|}
\hline Author(s) & Year & Publication & Data & Estimation design & Main findings \\
\hline & & Studies & $\begin{array}{ll} & \text { firms } \\
\text { - } & \text { all sectors } \\
\text { - } & 1957-1977\end{array}$ & $\begin{array}{l}\text { - comparison of } \\
\text { growth rates by } \\
\text { size classes }\end{array}$ & size and firm growth (sales) \\
\hline Dunne/Hughes & 1994 & $\begin{array}{l}\text { Journal of Industrial } \\
\text { Economics }\end{array}$ & $\begin{array}{l}\text { - large UK firms } \\
\text { - all sectors } \\
\text { - } 1975-1985\end{array}$ & $\begin{array}{l}\text { - } \text { regression } \\
\text { - comparison of } \\
\text { growth rates by } \\
\text { size classes }\end{array}$ & $\begin{array}{l}\text { - negative relationship between firm } \\
\text { size and rate of net job creation } \\
\text { (decreases in firm size at } \\
\text { diminishing rate) } \\
\text { - negative relationship between firm } \\
\text { age and firm growth (employment) }\end{array}$ \\
\hline Dunne/Roberts/Samuelson & 1989 & $\begin{array}{l}\text { Quarterly Journal of } \\
\text { Economics }\end{array}$ & $\begin{array}{l}\text { - all U.S. start-ups } \\
\text { - } 1967-1977 \\
\text { - manufacturing }\end{array}$ & $\begin{array}{l}\text { - } \text { regression } \\
\text { - comparison of } \\
\text { growth rates by } \\
\text { size and age } \\
\text { classes }\end{array}$ & $\begin{array}{l}\text { - negative relationship between plant } \\
\text { size and plant growth (employment) } \\
\text { - negative relationship between plant } \\
\text { age and plant growth (employment) }\end{array}$ \\
\hline European Commission & 2015 & $\begin{array}{l}\text { Annual Report on } \\
\text { European SMEs }\end{array}$ & $\begin{array}{l}\text { - all firms in EU } \\
\text { - } 2008-2012 \\
\text { - all sectors }\end{array}$ & $\begin{array}{l}\text { - comparison of } \\
\text { growth rates by } \\
\text { size classes }\end{array}$ & $\begin{array}{l}\text { - no clear relationship between firm } \\
\text { size and firm growth (employment) }\end{array}$ \\
\hline Evans & 1987 & $\begin{array}{l}\text { Journal of Industrial } \\
\text { Economics }\end{array}$ & $\begin{array}{l}\text { - U.S. firms } \\
\text { - manufacturing } \\
\text { - } 1976-1982\end{array}$ & - regression & $\begin{array}{l}\text { negative relationship between firm } \\
\text { size and firm growth (rate of } \\
\text { employment growth decreases in } \\
\text { firm size at diminishing rate ) }\end{array}$ \\
\hline Evans & 1987 & $\begin{array}{l}\text { Journal of Political } \\
\text { Economy }\end{array}$ & $\begin{array}{l}\text { - U.S. firms } \\
\text { - manufacturing } \\
\text { - } 1976-1982\end{array}$ & - regression & $\begin{array}{l}\text { - negative relationship between firm } \\
\text { size and firm growth (rate of } \\
\text { employment growth decreases in } \\
\text { firm size at diminishing rate) } \\
\text { - negative relationship between firm } \\
\text { age and firm growth }\end{array}$ \\
\hline Fariñas/Moreno & 2000 & $\begin{array}{l}\text { Review of Industrial } \\
\text { Organization }\end{array}$ & $\begin{array}{l}\text { - Spanish firms } \\
\text { - manufacturing } \\
\text { - } 1990-1995\end{array}$ & - regression & $\begin{array}{l}\text { - negative relationship between firm } \\
\text { size and firm growth (employment) } \\
\text { - negative relationship between firm } \\
\text { age and firm growth (employment) }\end{array}$ \\
\hline Gallagher/Daly/Thomason & 1991 & $\begin{array}{l}\text { Small Business } \\
\text { Economics }\end{array}$ & $\begin{array}{l}\text { - UK firms } \\
\text { - all sectors }\end{array}$ & $\begin{array}{l}\text { - comparison of } \\
\text { growth rates by }\end{array}$ & $\begin{array}{l}\text { - negative relationship between firm } \\
\text { size and firm growth (employment) }\end{array}$ \\
\hline
\end{tabular}




\begin{tabular}{|c|c|c|c|c|c|}
\hline Author(s) & Year & Publication & Data & Estimation design & Main findings \\
\hline & & & • 1985-1987 & size classes & $\begin{array}{l}\text { - negative net job creation by large } \\
\text { firms }(1000+\text { employees })\end{array}$ \\
\hline Haltiwanger/Jarmin/Miranda & 2013 & $\begin{array}{l}\text { The Review of Economics } \\
\text { and Statistics }\end{array}$ & $\begin{array}{l}\text { - all U.S. establishments } \\
\text { - all sectors } \\
\text { - } 1992-2005\end{array}$ & $\begin{array}{l}\text { - comparison of } \\
\text { growth rates by } \\
\text { size classes / age } \\
\text { classes }\end{array}$ & $\begin{array}{l}\text { no clear relationship between firm } \\
\text { size and firm growth (employment) } \\
\text { if controlled for firm age } \\
\text { - only new businesses with positive } \\
\text { net job creation }\end{array}$ \\
\hline Hall, B. H. & 1987 & $\begin{array}{l}\text { Journal of Industrial } \\
\text { Economics }\end{array}$ & $\begin{array}{l}\text { - publicy traded U.S. } \\
\text { firms } \\
\text { - manufacturing } \\
\text { - } 1972-1983\end{array}$ & - regression & $\begin{array}{l}\text { - negative relationship between firm } \\
\text { size and firm growth (employment) }\end{array}$ \\
\hline Harhoff/Stahl/Woywode & 1998 & $\begin{array}{l}\text { Journal of Industrial } \\
\text { Economics }\end{array}$ & $\begin{array}{l}\text { - German firms } \\
\text { - all sectors } \\
\text { - 1989-1994 }\end{array}$ & $\begin{array}{l}\text { - comparison of } \\
\text { growth rates by } \\
\text { size / age classes } \\
\text { - regression }\end{array}$ & $\begin{array}{l}\text { - negative relationship between firm } \\
\text { size and firm growth (employment) } \\
\text { - negative relationship between firm } \\
\text { age and firm growth (employment) }\end{array}$ \\
\hline Hart & 1962 & Economica & $\begin{array}{l}\text { - U.S. and UK firms } \\
\text { - manufacturing } \\
\text { - } 1931-1960\end{array}$ & $\begin{array}{l}\text { - comparison of } \\
\text { growth rates by } \\
\text { size classes }\end{array}$ & $\begin{array}{l}\text { - no clear relationship between firm } \\
\text { size and firm growth (employment) }\end{array}$ \\
\hline Headd & 2010 & Working paper & $\begin{array}{l}\text { - U.S. establishments } \\
\text { - all sectors } \\
\text { - } 1998-2006 \\
\end{array}$ & $\begin{array}{l}\text { - comparison of } \\
\text { growth rates by } \\
\text { size classes }\end{array}$ & $\begin{array}{l}\text { negative relationship between firm } \\
\text { size and firm growth (employment) }\end{array}$ \\
\hline Headd/Kirchhoff & 2009 & $\begin{array}{l}\text { Journal of Small Business } \\
\text { Management }\end{array}$ & $\begin{array}{l}\text { - } \text { all single- } \\
\text { establishment firms } \\
(1+\text { employees }) \\
\text { - } \text { all sectors } \\
\text { - } 1992-2002\end{array}$ & $\begin{array}{l}\text { - comparison of } \\
\text { growth rates by } \\
\text { size classes / age } \\
\text { classes }\end{array}$ & $\begin{array}{l}\text { - negative relationship between firm } \\
\text { age and firm growth (employment) } \\
\text { - most firms do not grow much after } \\
\text { start up }\end{array}$ \\
\hline Heshmati & 2001 & $\begin{array}{l}\text { Small Business } \\
\text { Economics }\end{array}$ & $\begin{array}{l}\text { - all small firms } \\
\text { - all sectors } \\
\text { - } 1993-1998\end{array}$ & - regression & $\begin{array}{l}\text { no clear relationship between firm } \\
\text { size and firm growth: negative for } \\
\text { employment, positive for sales } \\
\text { growth negatively related to size }\end{array}$ \\
\hline Hohti & 2000 & Small Business & $\begin{array}{l}\text { - all Finnish } \\
\text { establishments }(5+\end{array}$ & $\begin{array}{l}\text { - comparison of } \\
\text { growth rates by }\end{array}$ & $\begin{array}{l}\text { - no clear relationships between } \\
\text { establishment size and }\end{array}$ \\
\hline
\end{tabular}




\begin{tabular}{|c|c|c|c|c|c|}
\hline Author(s) & Year & Publication & Data & Estimation design & Main findings \\
\hline & & Economics & $\begin{array}{l}\text { employees) } \\
\text { - } \text { manufacturing } \\
\text { - } 1980-1994\end{array}$ & size classes & establishment growth (employment) \\
\hline Hymer/Pashigan & 1962 & $\begin{array}{l}\text { Journal of Political } \\
\text { Economy }\end{array}$ & $\begin{array}{l}\text { - largest U.S. firms } \\
\text { - } \text { manufacturing } \\
\text { - } 1946-1955\end{array}$ & - regression & $\begin{array}{l}\text { no clear relationship between firm } \\
\text { size and firm growth (employment) }\end{array}$ \\
\hline Kirchhoff/Phillips & 1988 & $\begin{array}{l}\text { Journal of Business } \\
\text { Venturing }\end{array}$ & $\begin{array}{l}\text { - U.S. firms } \\
\text { - manufacturing } \\
\text { - } 1976-1984\end{array}$ & $\begin{array}{l}\text { - comparison of } \\
\text { growth rates by } \\
\text { size classes }\end{array}$ & $\begin{array}{l}\text { - negative relationship between firm } \\
\text { size and rate of net job creation } \\
\text { - new firms account for majority of } \\
\text { net job creation }\end{array}$ \\
\hline Kumar & 1985 & $\begin{array}{l}\text { Journal of Industrial } \\
\text { Economics }\end{array}$ & $\begin{array}{l}\text { - } \text { quoted UK firms } \\
\text { - all sectors } \\
\text { - } 1960-1976\end{array}$ & - regression & $\begin{array}{l}\text { - slightly negative relationship } \\
\text { between firm size and rate of net } \\
\text { job creation }\end{array}$ \\
\hline Liu/Tsou/Hammitt & 1999 & Economics Letters & $\begin{array}{l}\text { - Taiwanese firms } \\
\text { - manufacturing } \\
\text { - 1990-1994 }\end{array}$ & - regression & $\begin{array}{l}\text { - negative relationship between plant } \\
\text { size and plant growth (employment) } \\
\text { - negative relationship between plant } \\
\text { age and plant growth (employment) }\end{array}$ \\
\hline Lotti & 2007 & $\begin{array}{l}\text { Industrial and Corporate } \\
\text { Change }\end{array}$ & $\begin{array}{l}\text { - } \text { Italian firms } \\
\text { - manufacturing and } \\
\text { service } \\
\text { - } 1993-1998\end{array}$ & $\begin{array}{l}\text { - } \text { regression } \\
\text { - comparison of } \\
\text { growth rates by } \\
\text { size classes / age } \\
\text { classes }\end{array}$ & $\begin{array}{l}\text { - negative relationship between firm } \\
\text { size and firm growth (rate of } \\
\text { employment growth decreases in } \\
\text { firm size at diminishing rate) } \\
\text { - negative relationship between firm } \\
\text { age and firm growth (employment) }\end{array}$ \\
\hline Lotti/Santarelli/Vivarello & 2003 & $\begin{array}{l}\text { Journal of Evolutionary } \\
\text { Economics }\end{array}$ & $\begin{array}{l}\text { - } \text { all new firms }(1+ \\
\text { employees) } \\
\text { - } \text { manufacturing } \\
\text { - } 1987-1993\end{array}$ & - regression & $\begin{array}{l}\text { negative relationship between firm } \\
\text { size and firm growth (employment) } \\
\text { only for new and small firms }\end{array}$ \\
\hline Mansfield & 1962 & $\begin{array}{l}\text { The American Economic } \\
\text { Review }\end{array}$ & $\begin{array}{l}\text { - large U.S. firms } \\
\text { - manufacturing sector } \\
\text { - } 1916-1959\end{array}$ & - regression & $\begin{array}{l}\text { - negative relationship between firm } \\
\text { size and firm growth (employment) } \\
\text { among surviving firms }\end{array}$ \\
\hline Mata/Portugal & 1994 & $\begin{array}{l}\text { Journal of Industrial } \\
\text { Economics }\end{array}$ & $\begin{array}{l}\text { - all Portuguese start-ups } \\
\text { (5+ employees) }\end{array}$ & $\begin{array}{l}\text { - comparison of } \\
\text { numbers of firms }\end{array}$ & $\begin{array}{l}\text { - negative relationship between firm } \\
\text { size and firm growth (employment) }\end{array}$ \\
\hline
\end{tabular}




\begin{tabular}{|c|c|c|c|c|c|}
\hline Author(s) & Year & Publication & Data & Estimation design & Main findings \\
\hline & & & $\begin{array}{l}\text { - manufacturing } \\
\text { - 1981-1988 }\end{array}$ & in size classes & \\
\hline Mata/Portugal/Guimaraes & 1995 & $\begin{array}{l}\text { International Journal of } \\
\text { Industrial Organization }\end{array}$ & $\begin{array}{l}\text { - all Portuguese plants } \\
\text { - manufacturing } \\
\text { - } 1981-1990\end{array}$ & - regression & $\begin{array}{l}\text { - negative relationship between firm } \\
\text { size and firm growth (employment) }\end{array}$ \\
\hline Mohnen/Nasev & 2008 & $\begin{array}{l}\text { Betriebswirtschaftliche } \\
\text { Forschung und Praxis }\end{array}$ & $\begin{array}{l}\text { - German SMEs } \\
\text { - all sectors } \\
\text { - } 2001-2003\end{array}$ & - regression & $\begin{array}{l}\text { - negative relationship between firm } \\
\text { size and firm growth (employment) } \\
\text { - negative relationship between firm } \\
\text { age and firm growth (employment) } \\
\text { only among new firms }\end{array}$ \\
\hline Neumark/Wall/Zhang & 2011 & $\begin{array}{l}\text { The Review of Economics } \\
\text { and Statistics }\end{array}$ & $\begin{array}{l}\text { - all U.S. establishments } \\
\text { - all sectors } \\
\text { - } 1992-2004\end{array}$ & $\begin{array}{l}\text { - comparison of } \\
\text { growth rates by } \\
\text { size classes }\end{array}$ & $\begin{array}{l}\text { - negative relationship between firm } \\
\text { size and firm growth (employment) } \\
\text { - only small firms (max. } 20 \\
\text { employees) with positive net job } \\
\text { creation }\end{array}$ \\
\hline Samuels & 1965 & $\begin{array}{l}\text { Review of Economic } \\
\text { Studies }\end{array}$ & $\begin{array}{l}\text { - U.S. firms } \\
\text { - all sectors } \\
\text { - } 1950-1960\end{array}$ & $\begin{array}{l}\text { - comparison of } \\
\text { growth rates by } \\
\text { size classes }\end{array}$ & $\begin{array}{l}\text { - positive relationship between firm } \\
\text { size and firm growth (employment) } \\
\text { among surviving firms }\end{array}$ \\
\hline Santarelli/Vivarelli & 2002 & $\begin{array}{l}\text { Industrial and Corporate } \\
\text { Change }\end{array}$ & $\begin{array}{l}\text { - Italian start-ups } \\
\text { - electrical/electronic } \\
\text { engineering } \\
\text { - } 1987-1993\end{array}$ & $\begin{array}{l}\text { - } \text { regression } \\
\text { - } \text { comparison of } \\
\text { growth rates by } \\
\text { size classes }\end{array}$ & $\begin{array}{l}\text { - negative relationship between firm } \\
\text { size and firm growth (employment); } \\
\text { less pronounced among established } \\
\text { firms } \\
\text { - negative relationship between firm } \\
\text { age and firm growth (employment) }\end{array}$ \\
\hline Singh/Whittington & 1975 & $\begin{array}{l}\text { Review of Economic } \\
\text { Studies }\end{array}$ & $\begin{array}{l}\text { - all quoted UK firms } \\
\text { - all sectors } \\
\text { - } 1948-1960\end{array}$ & $\begin{array}{l}\text { - } \text { regression } \\
\text { - comparison of } \\
\text { growth rates by } \\
\text { size classes }\end{array}$ & $\begin{array}{l}\text { - positive relationship between firm } \\
\text { size and firm growth (employment) } \\
\text { among surviving firms }\end{array}$ \\
\hline Tang & 2015 & Empirical Economics & $\begin{array}{l}\text { - } \text { all Swedish companies } \\
\text { - energy sector } \\
\text { - } 1997-2011 \\
\end{array}$ & - regression & $\begin{array}{l}\text { - negative relationship between firm } \\
\text { size and firm growth (employment) } \\
\text { but only for young firms }\end{array}$ \\
\hline Variyam/Kraybill & 1992 & Economics Letters & - SMEs in Georgia & - regression & $\begin{array}{l}\text { - negative relationship between firm } \\
\text { size and firm growth (employment) }\end{array}$ \\
\hline
\end{tabular}




\begin{tabular}{|c|c|c|c|c|c|}
\hline Author(s) & Year & Publication & Data & Estimation design & Main findings \\
\hline & & & $\begin{array}{l}\text { - all sectors } \\
\text { - } 1986-1991\end{array}$ & & $\begin{array}{l}\text { - negative relationship between firm } \\
\text { age and firm growth (employment) }\end{array}$ \\
\hline Voulgaris/Papadogonas/Agiomirigianakis & 2005 & $\begin{array}{l}\text { Review of Development } \\
\text { Economics }\end{array}$ & $\begin{array}{l}\text { - all Greek firms } \\
\text { - manufacturing } \\
\text { - 1995-1999 }\end{array}$ & $\begin{array}{l}\text { - } \text { regression } \\
\text { - comparison of } \\
\text { growth rates by } \\
\text { size classes / age } \\
\text { classes }\end{array}$ & $\begin{array}{l}\text { - negative relationship between firm } \\
\text { size and firm growth (employment) } \\
\text { - negative relationship between firm } \\
\text { age and firm growth (employment) } \\
\text { - only young firms (5 years) with } \\
\text { positive net job creation }\end{array}$ \\
\hline
\end{tabular}

